\title{
28. CENOZOIC PLANKTONIC BIOSTRATIGRAPHY AND PALEOCEANOGRAPHY OF THE TROPICAL WESTERN INDIAN OCEAN
}

\author{
Edith Vincent, Department of Geological Sciences, University of Southern California, \\ Los Angeles, California
}

\begin{abstract}
Eight sites drilled during DSDP Leg 24 in the tropical western Indian Ocean provide a nearly complete record of major Cenozoic and paleoceanographic events. Sites 231,232, and 233 in the Gulf of Aden penetrated Neogene hemipelagic calcareous oozes; these expanded sections are of special interest for investigation of planktonic events. Sites 234 and 235 in the Somali Basin lay close to or below the CCD throughout the time of deposition and are not well suited for biostratigraphic investigation. Sites 236, 237, and 238 in the central western Indian Ocean recovered Pleistocene through Oligocene calcareous oozes and Eocene and Paleocene chert-bearing chalk. The occurrence of well-preserved calcareous and siliceous microfossils in the late Neogene and Eocene of Sites 238 and 237 , respectively, permits the direct comparison and correlation of zonation schemes based on the two microfossil types for these time intervals.

Sediment-based contacts were penetrated, and basal sediment ages determined, at four sites. The opening of the Gulf of Aden predates 13 m.y. The sundering of the Chagos and Saya de Malha regions is at least as old as $32-34$ m.y. B.P. The basement age at Site 235 (65-67 m.y. B.P.) implies the presence of a discontinuity between this site and the magnetic lineations identified to the east, and of an offset of the magnetic anomalies to the north. A discrepancy between the biostratigraphic age of the basal sediments (57-58 m.y. B.P.) at Site 236 and the magnetic age of basement $(10 \mathrm{~m} . \mathrm{y}$. older according to the prevailing paleomagnetic time scale) is consistent with similar discrepancies noted at other DSDP sites. This finding supports the adjustments proposed for the Heirtzler et al. (1968) paleomagnetic scale, including a reduction of the ages for the early Cenozoic.

Similar tropical planktonic assemblages recovered at the various sites reflect a common oceanographic history throughout the Cenozoic. Prior to the late Paleocene, a thick sequence accumulated rapidly $(68 \mathrm{~m} / \mathrm{m} . \mathrm{y}$.) at Site 237 in upper bathyal depths, with an added influx of displaced neritic sediments from nearby shallow banks. After the deepening of this site in the late Paleocene, normal pelagic sedimentation proceeded at a rate about one-sixth as fast, similar to contemporaneous rates at Site 236 . An interval of much-reduced accumulation or nondeposition spans the Paleocene/Eocene boundary at both sites.

In the late Eocene-early Oligocene, when Antarctic Bottom Water moved northward into the Indian Ocean, the accumulation rate and preservation of calcareous ooze decreased. Preservation of planktonic foraminifera remained poor during the Oligocene and early Miocene, and hiatuses or condensed series occurred during this interval. A change in the circulation system occurred by middle Miocene time. When India moved north of the equator, the development of the modern south equatorial circulation pattern resulted in higher surface productivity, reflected in the late Neogene sequences by a higher content of siliceous microfossils and by sedimentation rates about three times as high as those
\end{abstract}


prevailing during the preceding Oligocene and early Miocene. An episode of reworking in the early late Miocene, following a 2-m.y. interval of reduced sedimentation spanning the middle/late Miocene boundary, suggests the advent of large-scale bottom current activity in the central western Indian Ocean, Gulf of Aden, and Arabian Sea.

\section{INTRODUCTION}

During Leg 24 of the Deep Sea Drilling Project, eight sites were drilled in the western Indian Ocean in three distinct geographic areas: the Gulf of Aden, the northwestern Somali Basin, and the Mascarene Plateau/Central Indian Ridge/Chagos-Laccadive Ridge complex area (Figure 1, Table 1). Continuous coring and a high rate of recovery at most sites have provided a record of Cenozoic planktonic, sedimentary, and paleooceanographic events in the tropical Indian Ocean.

The sediments recovered at these sites represent a virtually complete section of the Cenozoic (Figure 2). Of special interest is the occurrence of well-preserved calcareous and siliceous microfossils in the late Neogene of Site 238 and the Eocene of Site 237. These sequences permit direct comparison and correlation of zonation schemes based on the two microfossil types for these time intervals.

Age assignments and estimates of sedimentation rates were made according to the correlation and time relationships presented in Figures 3 and 4. The correlation of Blow's (1969) planktonic foraminiferal zones with those of Martini (1971) for calcareous nannoplankton, and the assignment of absolute ages to the zone boundaries, are from Berggren (1973) and Berggren and Van Couvering (1974) for the late Neogene and from Berggren (1972) for the Paleogene and early Miocene. ${ }^{1}$ The correlation of the early Eocene Discoaster sublodoensis and D. lodoensis nannofossil zones with foraminiferal equivalents, however, has been slightly modified from Berggren (1972) to accommodate data from Bystricka (1971) and Gibson (personal communication). Calcareous planktonic zonation schemes developed

\footnotetext{
${ }^{1}$ Since the completion of the manuscript for this paper, minor modifications have been made by Berggren and Van Couvering to the middle Miocene portion of their time scale (Van Couvering and Berggren, in press). These authors corrected the time span for paleomagnetic Epochs 10 and 11, which they had previously misinterpreted. They have altered the early/middle Miocene boundary (Orbulina Datum) from 14 to 15 m.y. B.P. and made minor adjustments in the ages of the zonal boundaries as a result of the correlation made by Theyer and Hammond (1974). According to the time scales of Van Couvering and Berggren (in press) and of Theyer and Hammond (1974), the time span of Epoch 11 is 10.7-11.6 m.y. and of Epochs 12 to 16, 11.6-17.6 m.y. The ages of the contemporaneous radiolarian zonal boundaries are: Cannartus pettersoni/Ommatartus antepenultimus, 10.7-10.8 m.y. (top of Epoch 11); Dorcadospyris alata/C. pettersoni, 11.3-11.4 m.y. (base of Epoch 11); and Calocycletta costata/D. alata, 15.5-15.6 (late Epoch 16).

Van Couvering and Berggren (in press) placed the Oligocene/ Miocene boundary at 23-23.5 m.y. within foraminiferal Zone N4 and the early portion of the Triquetrorhabdulus carinatus zone of Martini (NN 1). The base of N4 is thus lowered to $25 \mathrm{~m} . \mathrm{y}$. and placed within the Sphenolithus ciperoensis Zone (NP 25).
}

by various authors (Bukry, 1974b; Gartner, 1974; Roth, 1973, this volume) whose data are used in this paper are correlated to Martini's (1971) zonation. The ages recognized for the Neogene radiolarian zone boundaries are those proposed by Theyer and Hammond (1974), who recently calibrated the standard equatorial Pacific radiolarian zonation (Riedel and Sanfilippo, 1970, 1971) to the paleomagnetic reversal stratigraphy. The correlation of Paleogene radiolarian zones (Foreman, 1973; Riedel and Sanfilippo, 1970; Sanfilippo and Riedel, 1973) with those of the other microfossil groups is modified from Berggren (1972) according to data presented in Table 2, which shows the location of radiolarian zonal boundaries with respect to calcareous fossil zones as observed at various DSDP sites in the Indian and Pacific oceans. The relationship of the tropical Indian Ocean diatom zones (TID) defined by Schrader (this volume) to radiolarian zones is discussed below.

Biostratigraphic results for the principal Cenozoic microfossil groups are presented in preceding chapters of this volume and have been integrated in Figures 5 to 12 . In these figures, and in the discussion of the site summaries, calcareous nannoplankton data provided by Bukry and by Roth have been combined, but the nomenclature of Roth's zonation is utilized. The sedimentation rate curves in Figures 5 to 12 were drawn according to plots of calcareous plankton zones. Neogene radiolarian events are shown as well. Paleogene radiolarian and diatom events are plotted on the sedimentation rate curve at their depth of occurrence.

\section{SITE SUMMARIES}

\section{Gulf of Aden}

\section{Geologic and Lithologic Setting}

The Gulf of Aden is a young and mobile basin of intermediate depth bisected from east to west by Sheba Ridge, a seismically active zone which marks the spreading center (Matthews et al., 1967). Sheba Ridge is offset by several minor transform faults, and near its eastern end by a linear NNE-trending cleft, the 5360-meter-deep Alula-Fartak Trench. Three sites were drilled in this region. Site 231 is located in the inner Gulf of Aden, south of Sheba Ridge and $80 \mathrm{~km}$ north of Somalia and within the "Half Degree Square," an area extensively surveyed by Laughton et al. (1970). The site is located beyond magnetic Anomaly 5, southwest of a small fracture zone which offsets Sheba Ridge. Sites 232 and 233 were drilled on opposite sides of the Alula-Fartak Trench, a structure which has been the site of sedimentation since at least the late middle Miocene (Ramsay and Funnell,1969). Site 232 lies on the western edge of the Trench northeast of the Sheba Ridge rift zone, above a basement with a magnetic age about 10 m.y. Site 233 , on the eastern side of the Trench, is southwest of the rift, near magnetic Anomaly 3 . 


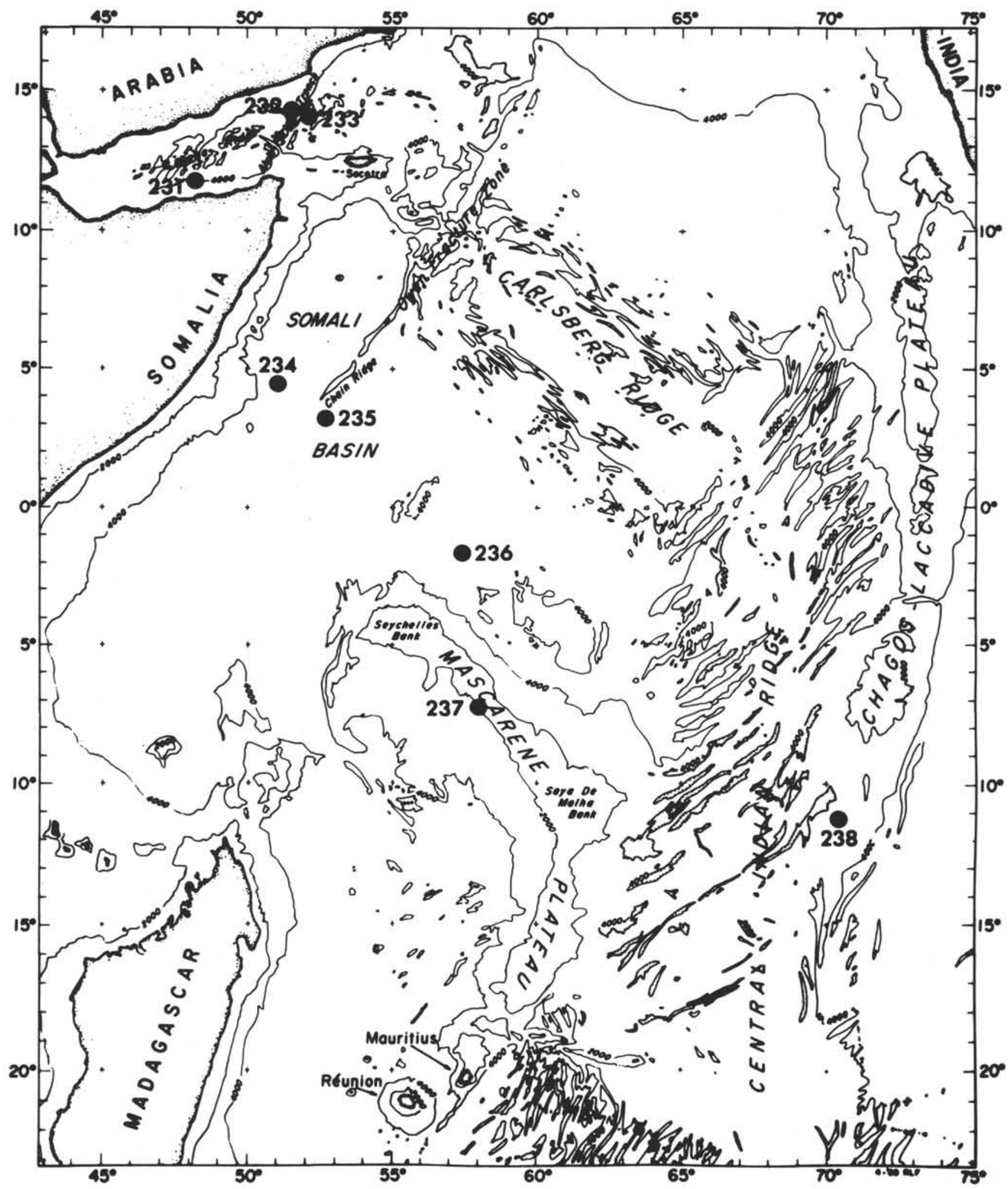

Figure 1. Location of DSDP Leg 24 sites. 
TABLE 1

Location of DSDP Leg 24 Sites

\begin{tabular}{cccc}
\hline Site & Latitude & Longitude & $\begin{array}{c}\text { Water } \\
\text { Depth (m) }\end{array}$ \\
\hline 231 & $11^{\circ} 53.41^{\prime} \mathrm{N}$ & $48^{\circ} 14.71^{\prime} \mathrm{E}$ & 2161 \\
232 & $14^{\circ} 28.93^{\prime} \mathrm{N}$ & $51^{\circ} 54.87^{\prime} \mathrm{E}$ & 1758 \\
& & & \\
233 & $14^{\circ} 19.68^{\prime} \mathrm{N}$ & $52^{\circ} 08.11^{\prime} \mathrm{E}$ & 1860 \\
& & & \\
234 & $04^{\circ} 28.966^{\prime} \mathrm{N}$ & $51^{\circ} 13.48^{\prime} \mathrm{E}$ & 4738 \\
& & & \\
235 & $03^{\circ} 14.06^{\prime} \mathrm{N}$ & $52^{\circ} 41.64^{\prime} \mathrm{E}$ & 5146 \\
236 & $01^{\circ} 40.62^{\prime} \mathrm{S}$ & $57^{\circ} 38.85^{\prime} \mathrm{E}$ & 4504 \\
237 & $07^{\circ} 04.99^{\prime} \mathrm{S}$ & $58^{\circ} 07.48^{\prime} \mathrm{E}$ & 1640 \\
238 & $11^{\circ} 09.21^{\prime} \mathrm{S}$ & $70^{\circ} 31.56^{\prime} \mathrm{E}$ & 2844 \\
\hline
\end{tabular}

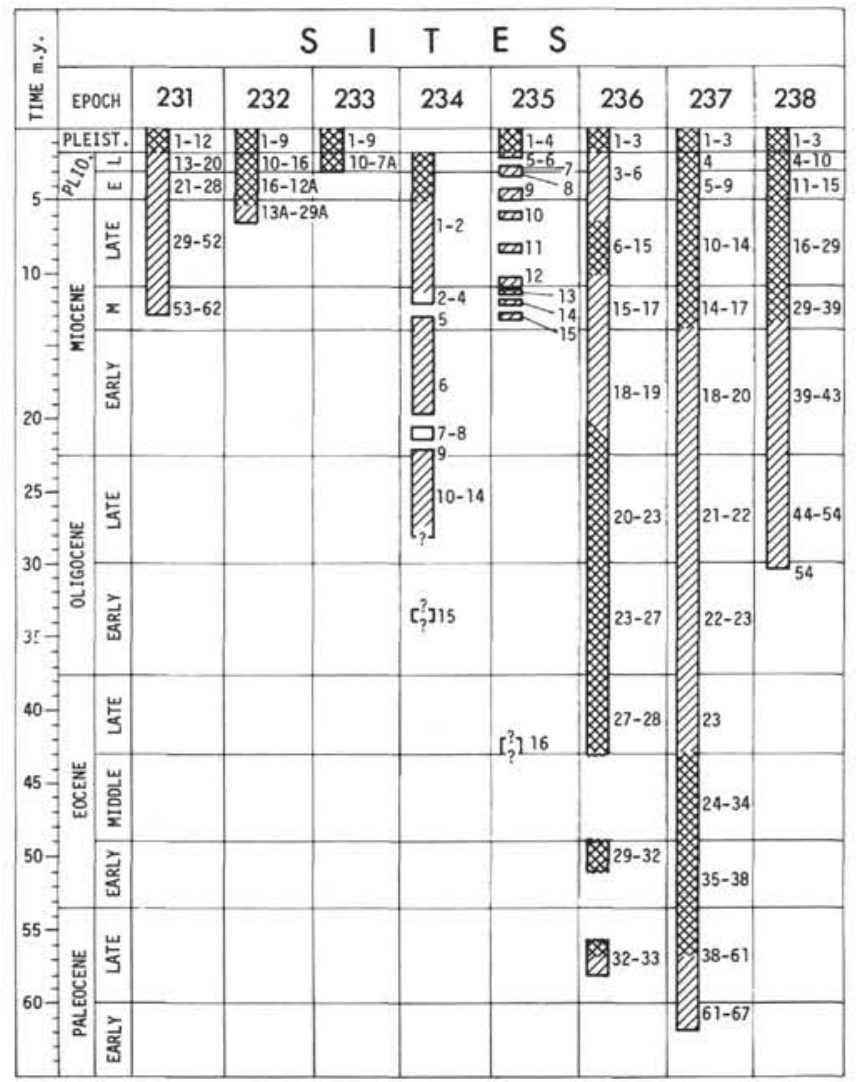

$\otimes$ SEDIMENTS WITH BOTH CALCAREOUS AND SILICEOUS MICROFOSSILS D CALCAREOUS SEDIMENTS LACKIHG SILICEOUS MICROFOSSILS SEDIMENTS BARREN OF MTCROFOSSILS $1-12$ : CORE NUMBERS

Figure 2. Stratigraphic distribution of sediments cored on DSDP Leg 24.

Good recovery was obtained from continuous coring at all three sites. Site 231 reached igneous basement (approximately 13 m.y. old), whereas Sites 232 and 233 (two holes were drilled at the same location at these two sites) were terminated for technical reasons after reaching "acoustic basement," a massive quartzose sandstone at Site 232, and a diabase sill at Site 233 .

The sedimentary sequences recovered at the three sites are similar and consist of late Neogene hemipelagic nanno- fossil oozes which accumulated at a high rate. The calcium carbonate content ranges from $30 \%$ to $60 \%$ at Site $231,5 \%$ to $60 \%$ at Site 232, and $40 \%$ to $70 \%$ at Site 233. Sediments are fine grained and contain a small proportion of sand-size particles $(<20 \%)$ except in sandy horizons. Intercalated sandy layers containing transported neritic material are common in the Pliocene and Pleistocene of Site 231 and occur occasionally throughout Site 232 and in the upper Pliocene sediments of Site 233.

Five lithologic units were distinguished at Site 231 on the basis of the presence or absence of sandy horizons. A sixth unit represents basaltic rocks with inclusions of recrystallized nannofossil chalk. At Site 232 sediments were divided into six lithologic units based on different proportions of clastic terrigenous components, and at Site 233 eight lithologic units were differentiated on the basis of variations in the abundance of micarb.

A significant terrigenous fraction, presumably airborne, is common in all samples and increases with age. Volcanic ash horizons occur in the Pliocene at all three sites. Pyrite is common to very abundant in some horizons; its abundance increases with depth.

\section{Abundance and Preservation of Microfossils}

Calcareous nannofossils are common to abundant and slightly etched throughout the sedimentary sequences. They are considerably altered, however, in the basalt inclusions at Site 231.

Foraminifera are abundant and moderately well preserved in the Pleistocene, where they are the dominant component of the coarse sediment fraction. They are less abundant in older sediments and show a significant degree of dissolution, whereas terrigenous components, pyrite, and/or radiolarians become common. Planktonic species dominate the Pleistocene foraminiferal assemblages and constitute over $90 \%$ of the total foraminiferal farina. The relative frequency of these forms is lower in older sediments (30\% in some horizons), while the percentage of benthonic foraminifera increases. The decrease with age in abundance of planktonic foraminifera, and the concomitant decrease in test preservation, are related to calcium carbonate dissolution. A decrease in calcium carbonate solution in the Pleistocene is also reflected by the common presence of pteropods in Pleistocene sediments. Benthonic foraminifera characteristic of bathyal environment are common throughout the sections. Shallow-water species, however, are frequently found in association with skeletal debris of pelecypods gastropods, echinoderms, and bryozoans in the Pleistocene and upper Pliocene sandy layers of Site 231, suggesting slumping from shelf areas.

Radiolarians are common to abundant and well to moderately well preserved throughout most of the sequences at Sites 232 and 233 and in the uppermost sediments at Site 231. These forms are present but poorly preserved in the remainder of the section at the latter site. Fish debris occurs commonly in sediments at Site 231 .

\section{Stratigraphic Boundaries}

The Pliocene/Pleistocene boundary was drawn at all three sites on the basis of nannofossil data. This boundary, placed at the highest occurrence of Discoaster brouweri 


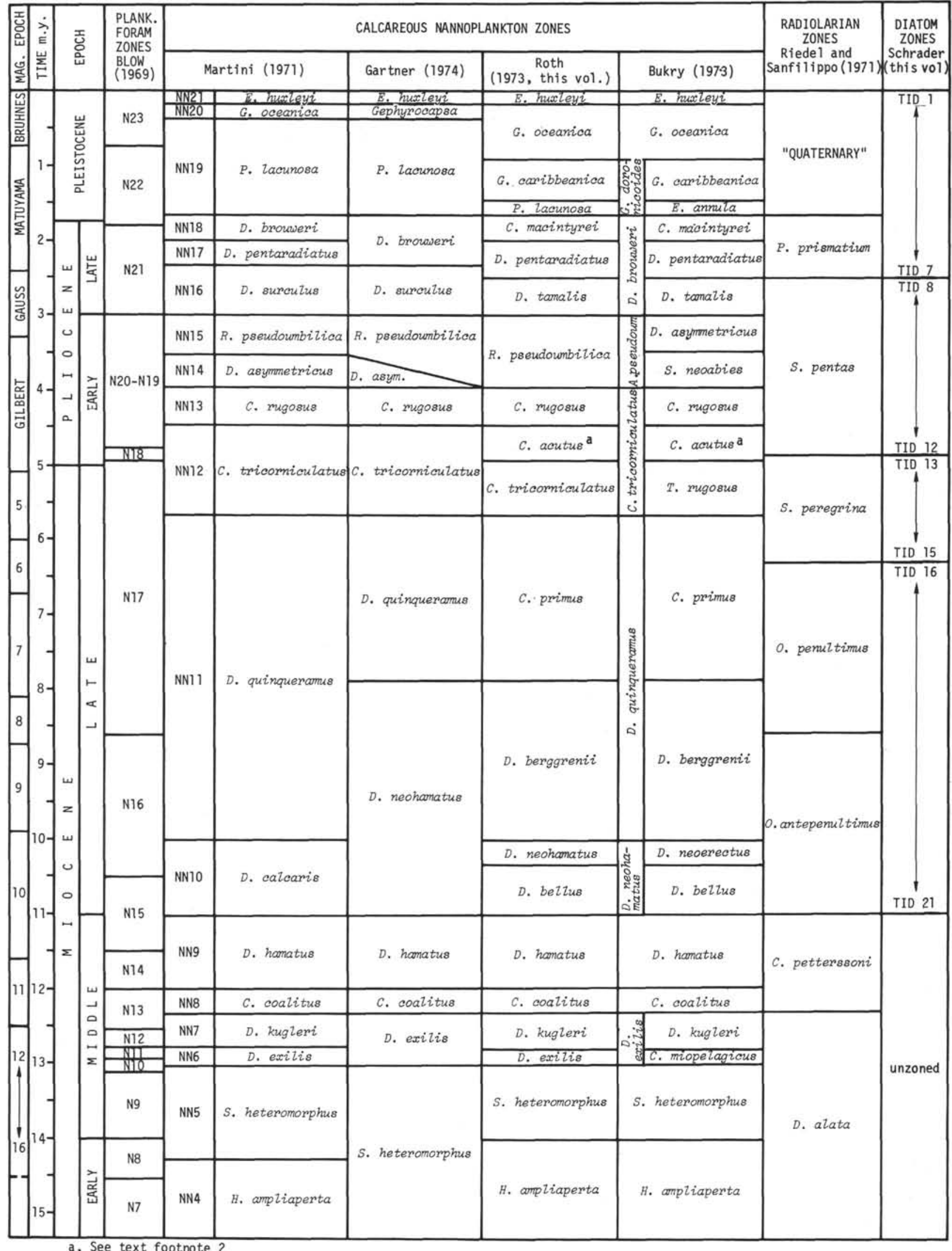

Figure 3. Time relationship and correlation of paleomagnetic epochs and late Neogene planktonic microfossil zones. See text for explanation. See references for generic abbreviations. 


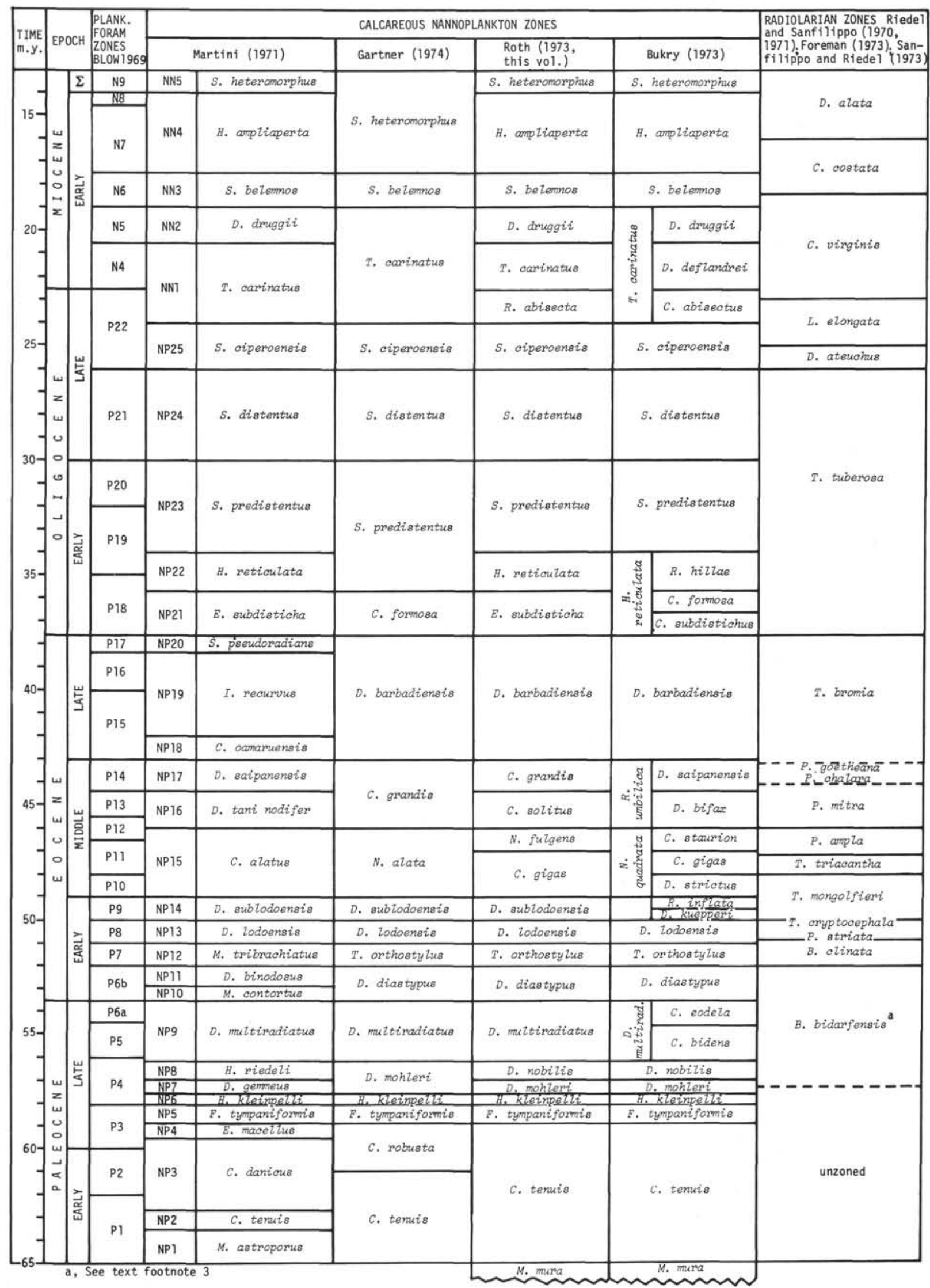

Figure 4. Time relationship and correlation of early Miocene and Paleogene planktonic microfossil zones. See text for explanation. See references for generic abbreviations. 
TABLE 2

Position of the Observed Paleogene Radiolarian Zonal Boundaries Within Cores and Within Calcareous Plankton Zones at Various DSDP Sites of the Indian and Pacific Oceans

\begin{tabular}{|c|c|c|c|c|c|c|c|c|c|}
\hline \multirow[b]{3}{*}{ Radiolarian Zonal Boundaries $^{\mathrm{a}, \mathrm{b}, \mathrm{c}, \mathrm{d}}$} & \multicolumn{6}{|c|}{ Leg 23} & \multicolumn{3}{|c|}{ Leg 24} \\
\hline & \multicolumn{3}{|c|}{ Site 220} & \multicolumn{3}{|c|}{ Site 219} & \multicolumn{3}{|c|}{ Site 237} \\
\hline & "్ & 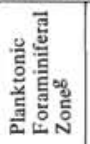 & 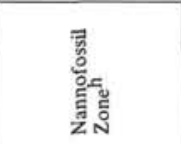 & है & 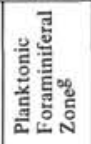 & 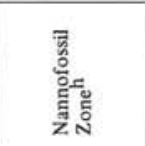 & हु & 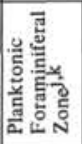 & 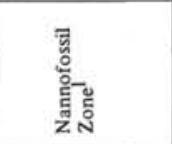 \\
\hline \multicolumn{10}{|l|}{ Calocycletta virginis/Lychnocanoma elongata } \\
\hline \multicolumn{10}{|l|}{ L. elongata/Dorcadospyris atenchus } \\
\hline D. atenchus/Theocyrtis tuberosa & 8. CC to $9-1$ & & $\begin{array}{l}\text { S. ciperoensis to } \\
\text { S. predistentus }\end{array}$ & & & & & & \\
\hline T. tuberosa/thyrsocyrtis bromia & $10, \mathrm{CC}$ to $11-1$ & & $\begin{array}{l}\text { S. predistentus. } \\
\text { H. reticulata }\end{array}$ & & & & & & \\
\hline \multicolumn{10}{|l|}{ T. bromia/Podocyrtis goetheana } \\
\hline \multicolumn{10}{|l|}{ P. goetheana/podocyrtis chalara } \\
\hline \multicolumn{10}{|l|}{ P. chalara/podocyrtis mitra } \\
\hline P. mitra/podocyrtis ampla & & & & $19-6$ to $19, \mathrm{CC}$ & $\begin{array}{l}\text { P14 to } \\
\text { P11 }\end{array}$ & $\begin{array}{l}\text { D. saipanensis } \\
\text { to } C \text {. staurion }\end{array}$ & $26-1$ to $27-1$ & P11 & $\begin{array}{l}\text { D. bifax/ } \\
\text { C. staurion bdry }\end{array}$ \\
\hline P. ampla/Thyrsocyrtis triacanthe & & & & $20-5$ to $20-6$ & $\begin{array}{l}\text { Early } \\
\text { P11 }\end{array}$ & C. staurion & $28-1$ to $29-1$ & P11 & C. staurion \\
\hline T. triacantha/Theocampe mongolfieri & $14-3$ to $14, \mathrm{CC}$ & $\begin{array}{l}\text { Early } \\
\text { P10 }\end{array}$ & $\begin{array}{l}\text { D. strictus- } \\
\text { R. inflata }\end{array}$ & below $21, \mathrm{CC}$ & $\begin{array}{l}\text { P10 or } \\
\text { older }\end{array}$ & $\begin{array}{l}\text { C. staurion or } \\
\text { older }\end{array}$ & $30-1$ to $32-2$ & P10-P9 & $\begin{array}{l}\text { C. gigas/ } \\
D \text {. strictus bdry }\end{array}$ \\
\hline $\begin{array}{l}\text { T. mongolfieri/Theocotyle cryptocephala } \\
\text { cryptocephala }\end{array}$ & $16-2$ to $16, \mathrm{CC}$ & Late P8 & $\begin{array}{l}\text { ca } D . \text { kuepperil } \\
\text { D. lodoensis bdry }\end{array}$ & & & & & & \\
\hline \multicolumn{10}{|c|}{$\begin{array}{l}\text { T. cryptocephala cryptocephala/phormocyrtis striata } \\
\text { striata }\end{array}$} \\
\hline \multicolumn{10}{|l|}{ P. striata striata/Buryella clinata } \\
\hline B. clinata/Bekoma bidarfensis & & & & & & & $37-1$ to $38-1$ & $\begin{array}{l}\text { P8 to } \\
\text { P6 }\end{array}$ & $\begin{array}{l}\text { T. orthostylus/ } \\
\text { D. diastypus bdry }\end{array}$ \\
\hline Oldest recognized $B$. bidarfensis & & & & & & & $42-1$ & P5-P4 & D. mohleri \\
\hline
\end{tabular}

\begin{tabular}{|c|c|c|c|c|c|c|c|c|c|}
\hline \multirow[b]{3}{*}{ Radiolarian Zonal Boundaries ${ }^{\mathrm{a}, \mathrm{b}, \mathrm{c}, \mathrm{d}}$} & \multicolumn{9}{|c|}{ Leg 10} \\
\hline & \multicolumn{3}{|c|}{ Site 94} & \multicolumn{3}{|c|}{ Site 95} & \multicolumn{3}{|c|}{ Site 96} \\
\hline & 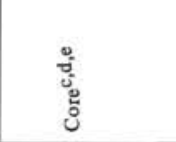 & 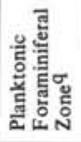 & 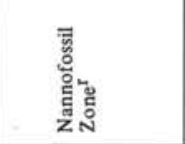 & 苞 & 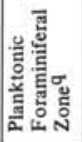 & 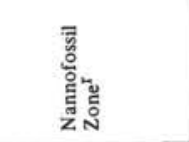 & 边 & 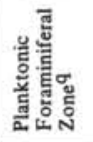 & 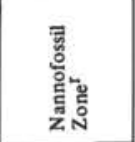 \\
\hline \multicolumn{10}{|l|}{ Calocycletta virginis/Lychnocanoma elongata } \\
\hline \multicolumn{10}{|l|}{ L. elongata/Dorcadospyris atenchus } \\
\hline D. atenchus/Theocyrtis tuberosa & & & & $2, \mathrm{CC}$ to $3-1$ & P21 & $\begin{array}{l}\text { ca S. ciperoensis/ } \\
\text { S. distentus bdry }\end{array}$ & $2-5$ to $2-6$ & P22 & S. ciperoensis \\
\hline$T$, tuberosa/thyrsocyrtis bromia & $13, \mathrm{CC}$ to $14-2$ & $\begin{array}{l}\text { P20 to } \\
\text { P16 }\end{array}$ & $\begin{array}{l}\text { S. predistentus } \\
\text { to } D \text {. barbadiensis }\end{array}$ & $5, \mathrm{CC}$ to $6-1$ & $\begin{array}{l}\text { P20 to } \\
\text { P15 }\end{array}$ & $\begin{array}{l}\text { S. predistentus } \\
\text { to } D \text {. barbadiensis }\end{array}$ & & & \\
\hline \multicolumn{10}{|l|}{ T. bromia/Podocyrtis goetheana } \\
\hline \multicolumn{10}{|l|}{ P. goetheana/podocyrtis chalara } \\
\hline \multicolumn{10}{|l|}{ P. chalara/podocyrtis mitra } \\
\hline P. mitra/podocyrtis ampla & $17, \mathrm{CC}$ to $18-1$ & P11 & $\begin{array}{l}\text { ca R. umbilical } \\
\text { N. quadrata bdry }\end{array}$ & & & & & & \\
\hline P. ampla/Thyrsocyrtis triacantha & $18, \mathrm{CC}$ to $19-1$ & P11 & N. quadrata & $7-3$ to $7-4$ & P11 & N. quadrata & & & \\
\hline T. triacantha/Theocampe mongolfieri & $20, \mathrm{CC}$ to $21-2$ & P10 & N. quadrata & & & & & & \\
\hline $\begin{array}{l}\text { T. mongolfieri/Theocotyle cryptocephala } \\
\text { cryptocephala }\end{array}$ & $24-3$ to $24-4$ & P10 & D. sublodoensis & & & & & & \\
\hline $\begin{array}{l}\text { T. cryptocephala cryptocephala/phormocyrtis striata } \\
\text { striata }\end{array}$ & $26-3$ to $26-4$ & P10 & D. sublodoensis & & & & & & \\
\hline P. striata striata/Buryella clinata & $28, C C$ to $29, O C$ & $\begin{array}{l}\text { P10 to } \\
\text { P7 }\end{array}$ & D. lodoensis & & & & & & \\
\hline B. clinata/Bekoma bidarfensis & $31, \mathrm{CC}$ to $32, \mathrm{CC}$ & P6 & $\begin{array}{l}\text { D. lodoensis } \\
\text { to } C \text {. eodela }\end{array}$ & & & & & & \\
\hline Oldest recognized $B$. bidarfensis & & & & & & & $3, \mathrm{CC}$ & P6 & C. codela \\
\hline $\begin{array}{ll}\text { aRiedel and Sanfilippo, 1970. } & \text { eGiven are the pair o } \\
\text { bRiedel and Sanfilippo, 1971. } & \text { fNigrini (this volume } \\
\text { cForeman, 1973. } & \text { gFleisher (1974). } \\
\text { dSanfilippo and Riedel, 1973. } & \text { hikry (1974). }\end{array}$ & & & & & $\begin{array}{l}\text { iSanfi } \\
\text { jHeim } \\
\text { kVinc } \\
\text { lRoth } \\
\text { qMcN } \\
\text { r Bukry }\end{array}$ & $\begin{array}{l}\text { ippo and Riedel (this } \\
\text { an, Frericks, and Vine } \\
\text { ent, Gibson, and Brun } \\
\text { (this volume); Bukry } \\
\text { ely (1973). } \\
\text { (1973). }\end{array}$ & $\begin{array}{l}\text { volume). } \\
\text { cent (this vo } \\
\text { n (this volum } \\
\text { (this volume }\end{array}$ & , using Ro & th's zonation. \\
\hline
\end{tabular}


TABLE 2 - Continued

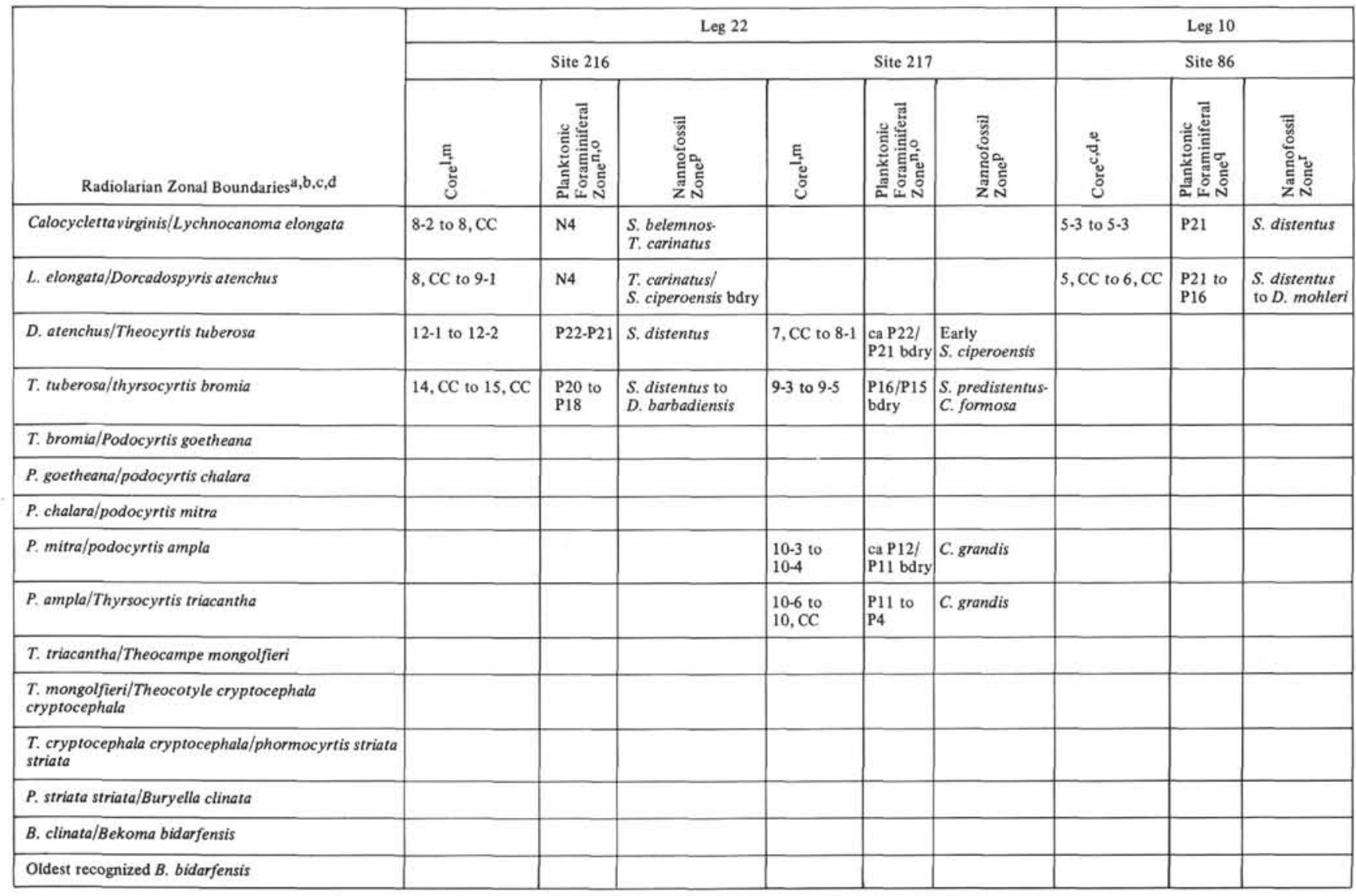

\begin{tabular}{|c|c|c|c|}
\hline \multirow[b]{3}{*}{ Radiolarian Zonal Boundaries ${ }^{\mathrm{a}, \mathrm{b}, \mathrm{c}, \mathrm{d}}$} & \multicolumn{3}{|c|}{ Leg 32} \\
\hline & \multicolumn{3}{|c|}{ Site 313} \\
\hline & $\begin{array}{l}\hat{2} \\
\text { s. } \\
0 \\
0\end{array}$ & 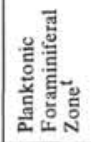 & 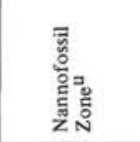 \\
\hline \multicolumn{4}{|c|}{ Calocycletta virginis/Lychnocanoma elongata } \\
\hline \multicolumn{4}{|l|}{ L. elongata/Dorcadospyris atenchus } \\
\hline \multicolumn{4}{|l|}{ D. atenchus/Theocyrtis tuberosa } \\
\hline \multicolumn{4}{|l|}{ T. tuberosa/thyrsocyrtis bromia } \\
\hline \multicolumn{4}{|l|}{ T. bromia/Podocyrtis goetheana } \\
\hline \multicolumn{4}{|l|}{ P. goetheana/podocyrtis chalara } \\
\hline \multicolumn{4}{|l|}{ P. chalara/podocyrtis mitra } \\
\hline \multicolumn{4}{|l|}{ P. mitra/podocyrtis ampla } \\
\hline \multicolumn{4}{|l|}{ P. ampla/Thyrsocyrtis triacantha } \\
\hline \multicolumn{4}{|c|}{ T. triacantha/Theocampe mongolfieri } \\
\hline \multicolumn{4}{|c|}{$\begin{array}{l}\text { T. mongolfieri/Theocotyle cryptocephala } \\
\text { cryptocephala }\end{array}$} \\
\hline \multicolumn{4}{|c|}{$\begin{array}{l}\text { T. cryptocephala cryptocephala/phormocyrtis striata } \\
\text { striata }\end{array}$} \\
\hline \multicolumn{4}{|l|}{ P. striata striata/Buryella clinata } \\
\hline B. clinata/Bekoma bidarfensis & $12-1$ to $12-2$ & P6 & T. orthostylus \\
\hline Oldest recognized $B$. bidarfensis & $13-6$ & P6 & D. diastypus \\
\hline
\end{tabular}

aRiedel and Sanfilippo, 1970. biedel and Sanfilippo, 1971. cForeman, 1973.

dSanfilippo and Riedel, 1973.
IRoth (this volume); Bukry (this volume), using Roth's zonation. mJohnson (1974).

nBerggren, Lohmann, and Poore (1974).

oMcGowran (1974).
PGartner (1974).

qMcNeely (1973)

rBukry (1973).

sForeman, personal communication.

tLuterbacher, personal communication.

uBukry, personal communication. 
(Pseudoemiliana lacunosa/Cyclococcolithina macintyreizonal boundary) falls 30 to 60 meters below the youngest occurrence of Pterocanium prismatium and the N22/N21 boundary. The latter is placed at the earliest common occurrence of Globorotalia truncatulinoides.

The early/late Pliocene boundary, placed at the base of the Discoaster tamalis Zone, falls in latest N20-N19 (Sites 231 and 232) and within the Spongaster pentas Zone (Site 232). The Miocene/Pliocene boundary drawn at the base of the Ceratolithus acutus Zone, falls within the Stichocorys peregrina Zone at Site 232 and approximates the base of the N18 Zone at Site 231. The boundary, however, could not be identified on the basis of foraminifera at Site 232 because forms intermediate between Globorotalia tumida tumida and Globorotalia tumida plesiotumida (the diagnostic species of Zones N18 and N17, respectively) were commonly found throughout the lower 30 meters of the section. Specimens attributable to G. tumida tumida occurred here well below the Miocene/Pliocene boundary as defined by nannofossils. The middle/late Miocene boundary was placed at Site 231 between the Discoaster neohamatus and Discoaster bellus zones, although the foraminiferal zonation indicates a higher position for this level (Figure 5).

\section{Age of Lowest Sediments}

At Site 231 sediments at 567.4 meters above the basalt, and below the altered volcanic ash, belong to foraminiferal Zone N12, and the chalk inclusions in the basalt at 567.8 and 569.4 meters contain nannofossils characteristic of the Sphenolithus heteromorphus Zone. These data permit a reliable age assignment of approximately $13 \mathrm{~m} . \mathrm{y}$. for the basalt/sediment contact.

The lower 37 meters of the section at Site 232 could not be dated because of poor recovery and the lack of sufficiently diagnostic fossils. The highest occurrence of Discoaster quinqueramus (at the Ceratolithus primus/C. tricorniculatus zonal boundary) and the highest occurrence of Ommatartus antepenultimus (in the early Stichocorys peregrina Zone), however, at 340 and 330 meters, respectively, allow an estimate to be made of the accumulation rate for the lower sediments.

These floral and faunal events have been calibrated with paleomagnetic reversal stratigraphy and have both been dated at approximately 5.7 m.y. in magnetic epoch 5 (Gartner, 1973; Theyer and Hammond, 1974). The good agreement between the position of these two fossil events in this section permits an age assignment of 5.7 m.y. for the sediments at about 335 meters, and implies that the sedimentary sequence between 273 and 335 meters accumulated over a time interval of approximately $0.7 \mathrm{~m} . \mathrm{y}$. Assuming a constant accumulation rate for sediments in the lower part of the section, an age of approximately 6.7 m.y. (late late Miocene) is estimated for the bottom of the hole at 434 meters.

At Site 233 sediments just above the diabase at 235 meters belong to the Discoaster tamalis, N21, and Spongaster pentas zones, and are therefore of early Pliocene age. They are younger than 3.5 m.y., the extinction datum of $S$. pentas (Theyer and Hammond, 1974), as this species was not found here. The highest occurrence (at 163 meters) of
Stichocorys peregrina, a species known to become extinct at about 2.5 m.y. B.P. (Theyer and Hammond, 1974), suggests a sedimentation rate of approximately $117 \mathrm{~m} / \mathrm{m}$.y. for the upper Pliocene sediments between 81 and 163 meters. If this rate remained constant during the late Pliocene, sediments above the diabase are approximately 3 m.y. old (earliest late Pliocene).

\section{Sediment Accumulation Rates}

High rates of accumulation were calculated for the hemipelagic nannofossil oozes recovered in the Gulf of Aden (Table 3). At Site 231 the average accumulation rate for the entire sedimentary sequence is $43.7 \mathrm{~m} / \mathrm{m} . \mathrm{y}$. The increased rate during the Pleistocene and late Pliocene (average of $59.3 \mathrm{~m} / \mathrm{m} . \mathrm{y}$.$) reflects the input of transported$ shallow-water material.

Pleistocene accumulation rates at Sites 232 and 233 ( 43.6 and $45 \mathrm{~m} / \mathrm{m} . \mathrm{y}$. , respectively) are comparable to the average typical values obtained at Site 231 . Higher rates, however, were obtained at both of these sites for older sediments. At Site 233 a high value of $117 \mathrm{~m} / \mathrm{m} . \mathrm{y}$. was calculated for the upper Pliocene, while at Site 232 average accumulation rates increase with age, reaching $88.6 \mathrm{~m} / \mathrm{m} . \mathrm{y}$. for the upper Miocene. It has been suggested that the siltstone and sandstone units in the upper Miocene at this site were emplaced by slumping and represent massive fault or slide blocks. There is no repetition of faunal events, however, and the fossil evidence indicates no juxtaposition of older rocks over younger sediments.

\section{Somali Basin}

\section{Geologic and Lithologic Setting}

The ponded sediments, 2 to $3 \mathrm{~km}$ thick, in the western Somali Basin, appear similar in aspect on widely separated reflection profiles, with an acoustically transparent layer separating the upper and lower stratified (partly turbidite) sequence (Bunce et al., 1967). Two sites were intermittently cored on either side of the Chain Ridge, in areas where deeper sediments onlap basement slopes beneath thinning younger layers and where it was hoped to reach and date basement. Site 234 is located east of Chain Ridge. Two penetrations were made, but the second was abandoned for technical difficulties after a single core at 247 meters. Site 235 , on the eastern flank of Chain Ridge, reached basement of Late Cretaceous age at 647 meters.

Sediments recovered at both sites are very fine-grained and consist of nannofossil oozes, nannofossil clays, and clays which yielded only a very small sand-sized fraction. Calcium carbonate content ranges from $0 \%$ to $45 \%$ at Site 234 and from $2 \%$ to $80 \%$ at Site 235 . Six and three lithologic units were defined at Sites 234 and 235, respectively, on the basis of variations in calcium carbonate content and color changes.

\section{Abundance and Preservation of Microfossils}

Only a few horizons contain a significant biogenic content at Site 234, which must have been close to the calcite compensation depth throughout the time of deposition of the recovered sediments. Poorly preserved nannofossils are present at a number of horizons, but are absent in others. 


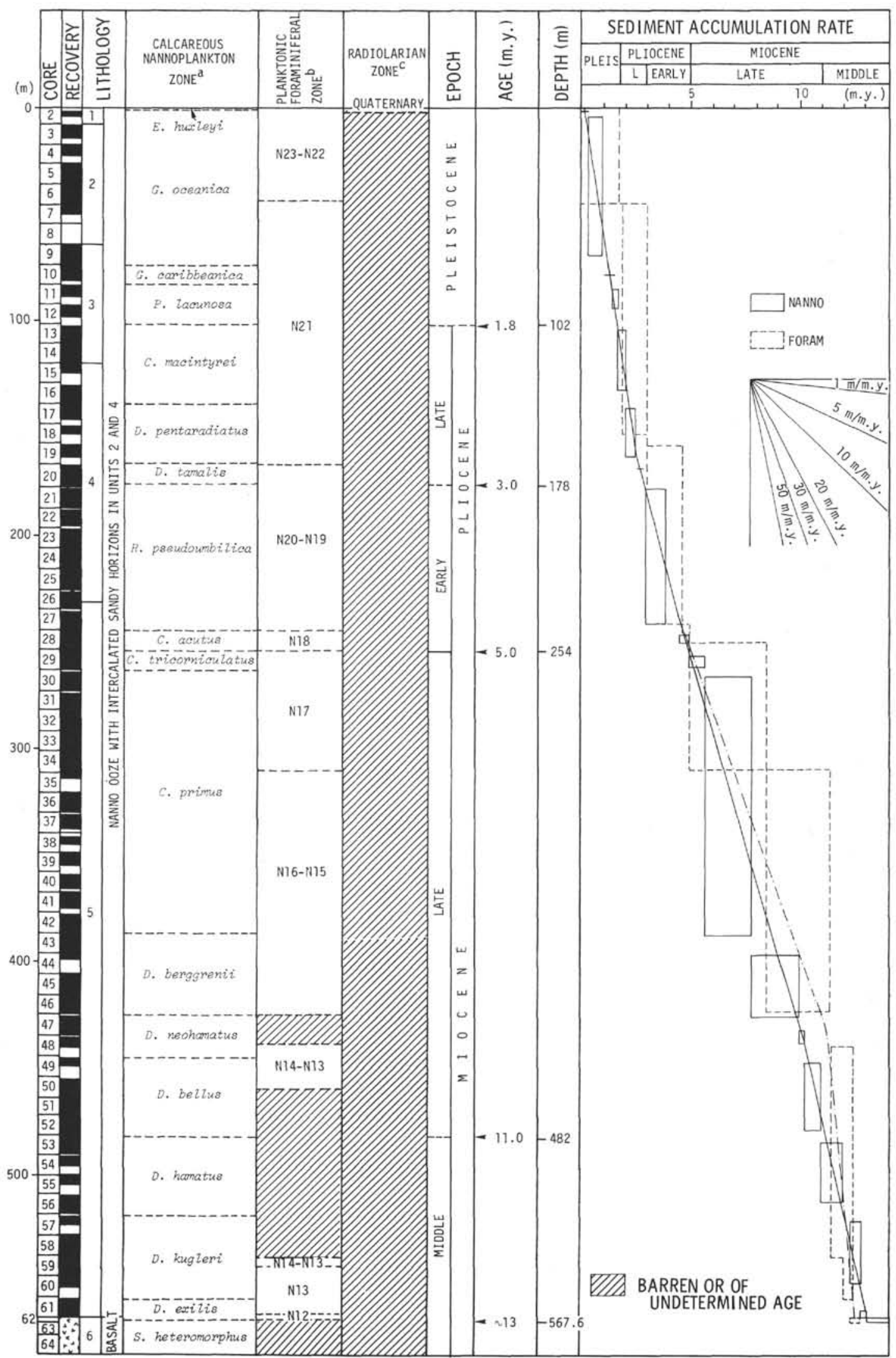

Figure 5. Planktonic biostratigraphy and sediment accumulation rate at Site 231. $a=$ Roth (this volume); Bukry (this volume), using Roth's zonation; $b=$ Vincent, Frerichs, and Heiman (this volume); and $c=$ Sanfilippo and Riedel (this volume). 


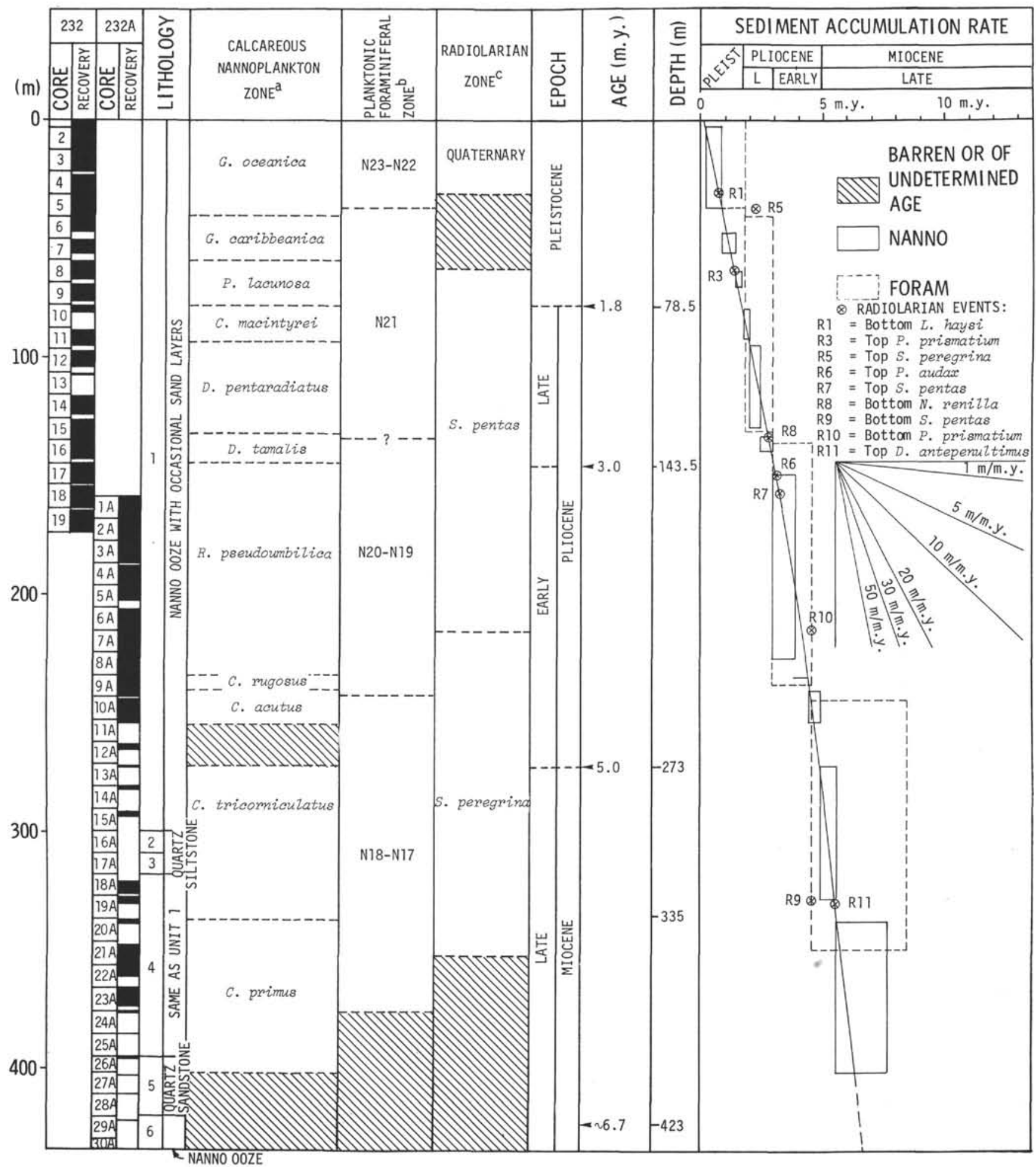

Figure 6. Planktonic biostratigraphy and sedimentation accumulation rate at Site 232. $a=$ Roth (this volume); Bukry (this volume), using Roth's zonation; $b=$ Vincent, Frerichs, and Heiman (this volume); and $c=$ Sanfilippo and Riedel (this volume). 
TABLE 3

Average Accumulation Rate of Stratigraphic Sequences at Leg 24 Sites

Average Accumulation Rates (m/m.y.)

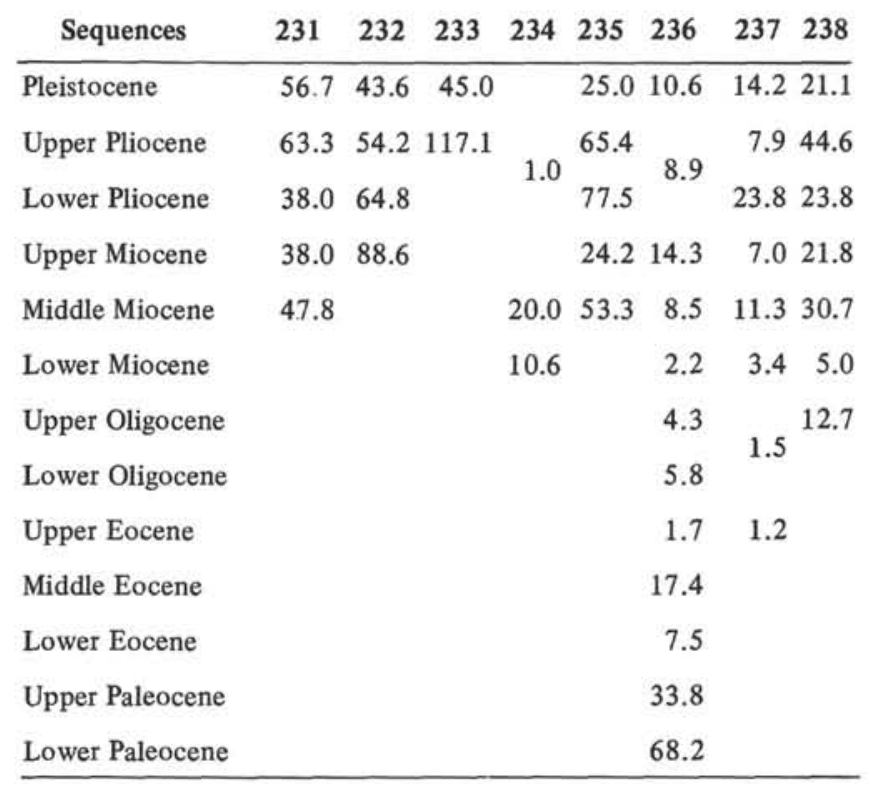

Poorly preserved foraminifera showing signs of intense dissolution are present in the upper 10 meters; they are rare or absent below this level. Sponge spicules and poorly preserved radiolarians, predominantly pyritized, are present in the upper 38 meters, but are almost totally absent below. Among other biogenic components are echinoderm debris and fish teeth. The latter are common in the lowermost part of the section where they are concentrated by dissolution.

Biogenic components are more frequent at Site 235. Nannofossils are moderately well to well preserved. While they are common throughout the upper 500 meters, they are absent below this level, except for rare and poorly preserved specimens in sediment inclusions in the basalt. Foraminifera are also rare and poorly preserved and show significant dissolution throughout the section. Some horizons, however, contain common to abundant uniformly minute well-preserved foraminifera. This fauna, which is composed mainly of planktonic species (>99\%) and is associated with pteropods and bivalve debris, may represent the distal parts of turbidites. Radiolarians are abundant and well preserved in the upper 76 meters, but they are less common and poorly preserved or absent below. Diatoms and sponge spicules are present throughout the section.

The high calcium carbonate content and sediment accumulation rates, the relatively good preservation of calcareous fossils, and the presence in some horizons of pteropods and bivalve debris at Site 235 evince displacement of sediments into much deeper water (from either Chain Ridge or Carlsberg Ridge) and rapid burial at the site.

\section{Stratigraphic Boundaries and Accumulation Rates}

Because of the paucity and poor preservation of microfossils in the Somali Basin, biostratigraphic investigations could not be conducted at all recovered horizons. Epoch boundaries which fall within undated intervals were located on the basis of sedimentation rates.

\section{Site 234 (Figure 8)}

A minimum of $11 \mathrm{~m} . y$. is condensed in the upper 11 meters, indicating an average accumulation rate of $1 \mathrm{~m} / \mathrm{m} . \mathrm{y}$. over that interval. The slow sedimentation was conducive to the formation of manganese nodules at the sediment surface. The biostratigraphy of this condensed series cannot be well defined, and mixing is shown by the discrepancy between foraminiferal and nannofossil zonations. The Pliocene and late Miocene were therefore not differentiated.

The middle/late Miocene and early/middle Miocene boundaries, both of which fall within intervals lacking biostratigraphic data, were inferred on the basis of sedimentation rate, whereas the Oligocene/Miocene boundary was placed at the Triquetrorhabdulus carinatus/Helicopontosphaera reticulata zonal boundary.

The presence of the Discoaster druggii Zone at approximately 78 meters indicates that most of the early Miocene (from 14 to about $20 \mathrm{~m} . \mathrm{y}$.) is condensed and that sediments accumulated at an average rate of $1 \mathrm{~m} / \mathrm{m} . \mathrm{y}$. over this interval. During the earliest Miocene (20 to 22.5 m.y.) the average rate was considerably higher $(33.5 \mathrm{~m} / \mathrm{m} . \mathrm{y}$.). The average rate for the entire lower Miocene series is 10.6 $\mathrm{m} / \mathrm{m} . \mathrm{y}$., and the average rate for the middle and lower Miocene is $13 \mathrm{~m} / \mathrm{m} . \mathrm{y}$.

The oldest dated sediments, in Core 13, are late Oligocene in age, possibly representing the Sphenolithus distentus Zone and indicate an average accumulation rate of at least $7 \mathrm{~m} / \mathrm{m}$.y. for the late Oligocene. Assuming a constant rate of accumulation for the lower sediments, the maximum age at the base of the section, at 242 meters, would be early Oligocene (approximately 34 m.y.).

\section{Site 235 (Figure 9)}

The Pliocene/Pleistocene boundary was drawn, as in the Gulf of Aden, on the basis of nannofossil data at approximately 45 meters. The youngest occurrence of Pterocanium prismatium, however, and the oldest appearance of Globorotalia truncatulinoides, both of which occur above the extinction of Discoaster brouweri in the Gulf of Aden, occur here below it. Because the initial appearances of Lamprocyrtis haysi and Pterocorys hertwigii and the extinction of $P$. prismatium occur in the same sequential order as in the Gulf of Aden, it is possible that the Pliocene/Pleistocene boundary here lies at about 76 meters below the highest occurrence of $D$. brouweri. The early/late Pliocene boundary was placed at the Discoaster tamalis/Reticulofenestra pseudoumbilica and N21/N20-N19 zone boundaries.

The average rate of accumulation for the upper Pliocene and Pleistocene series is $41.2 \mathrm{~m} / \mathrm{m} . \mathrm{y}$. The location of the Pliocene/Pleistocene boundary, as recognized from radiolarian and foraminiferal data, indicates a constant rate of sedimentation for that interval, whereas the nannofossil data imply an accumulation rate 2.5 times higher for the upper Pliocene than for the Pleistocene.

The Miocene/Pliocene boundary, between the Ceratolithus rugosus and C. primus zones, and between $\mathrm{N} 18$ and N17, and the middle/late Miocene boundary, between the 


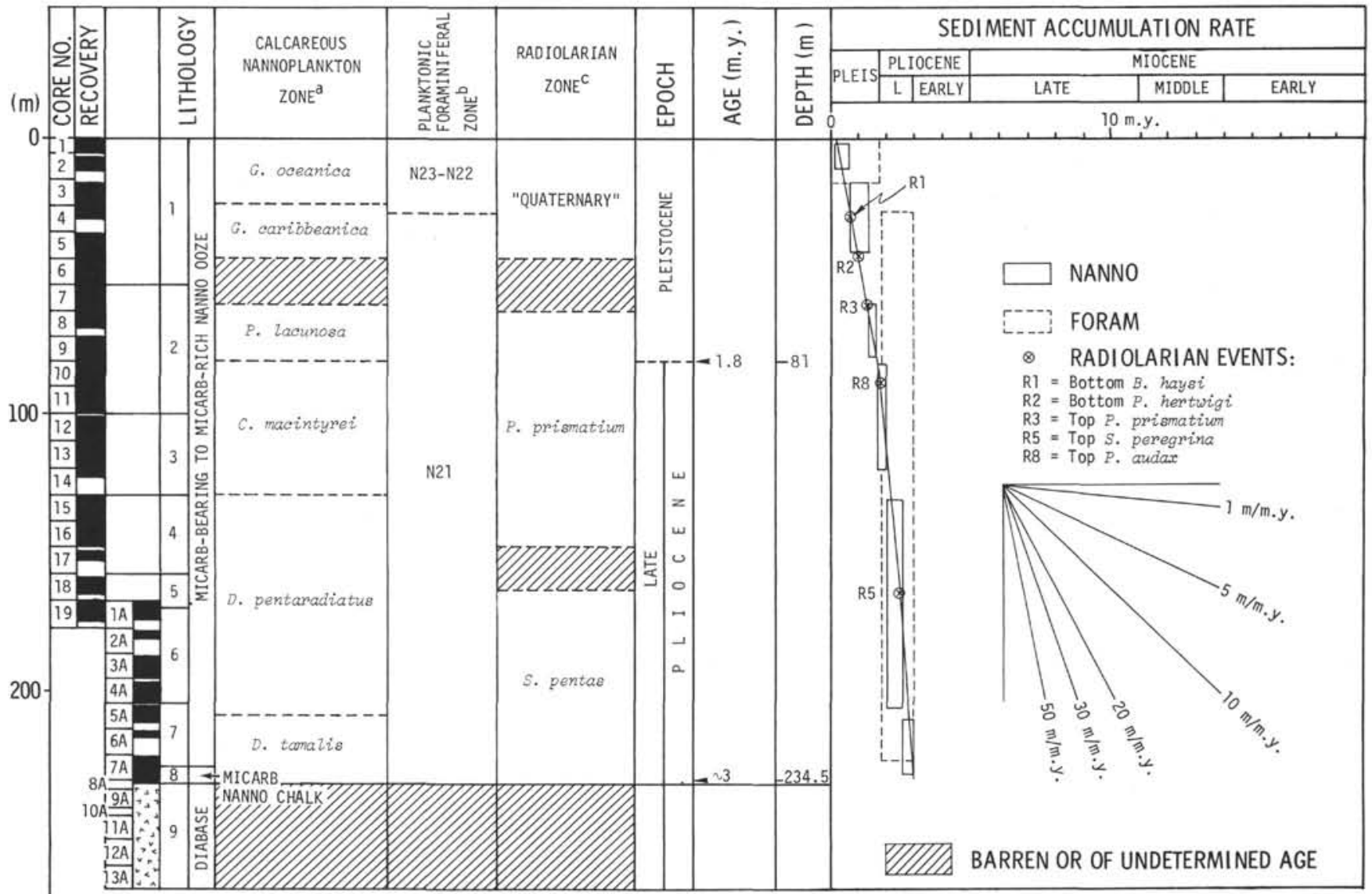

280

Figure 7. Planktonic biostratigraphy and sediment accumulation rate at Site 233. $a=$ Roth (this volume); Bukry (this volume), using Roth's zonation; $b=$ Vincent, Frerichs, and Heiman (this volume); and $c=$ Sanfilippo and Riedel (this volume).

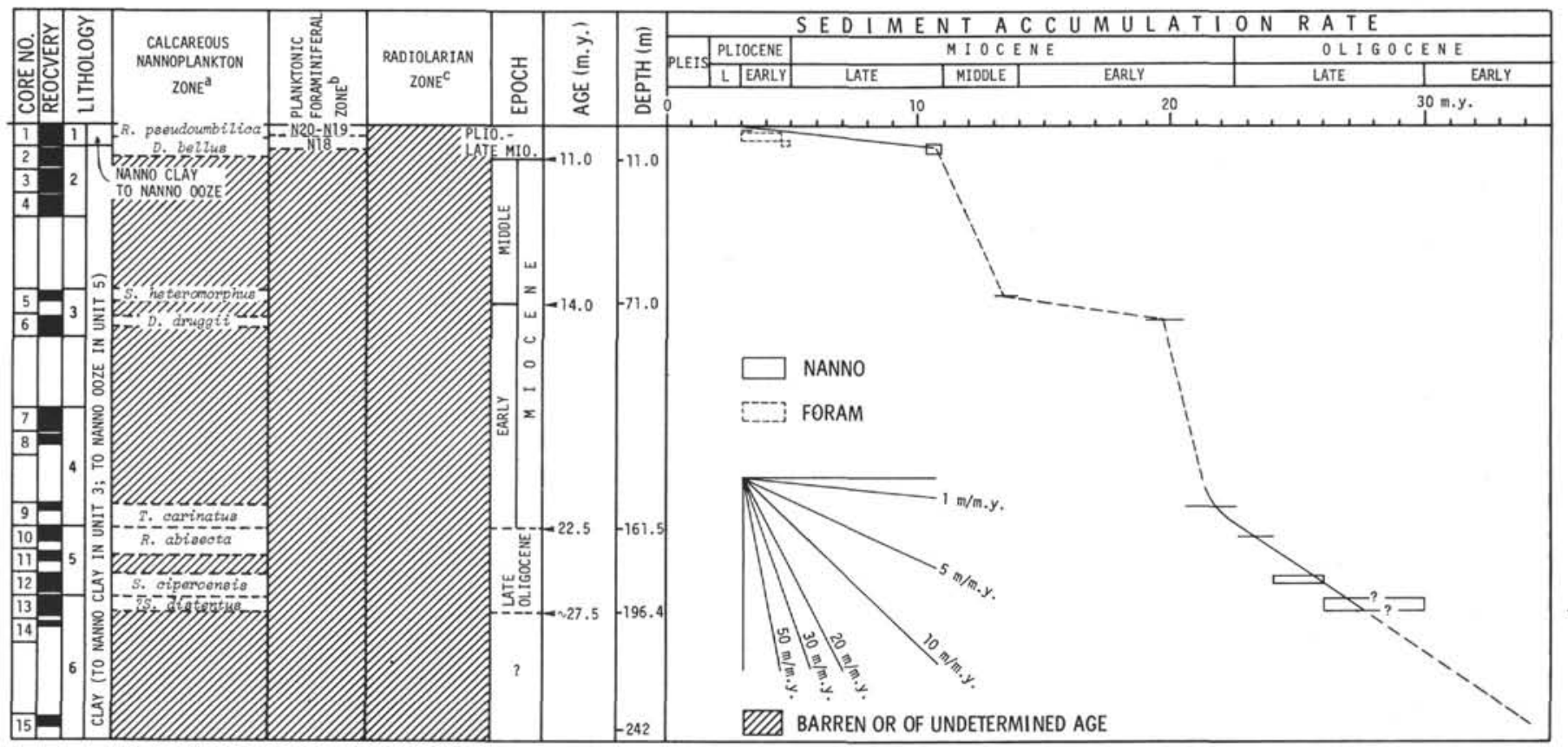

Figure 8. Planktonic biostratigraphy and sediment accumulation rate at Site 234. $a=$ Roth (this volume); Bukry (this volume), using Roth's zonation; $b=$ Vincent, Frerichs, and Heiman (this volume); and $c=$ Sanfilippo and Riedel (this volume). 


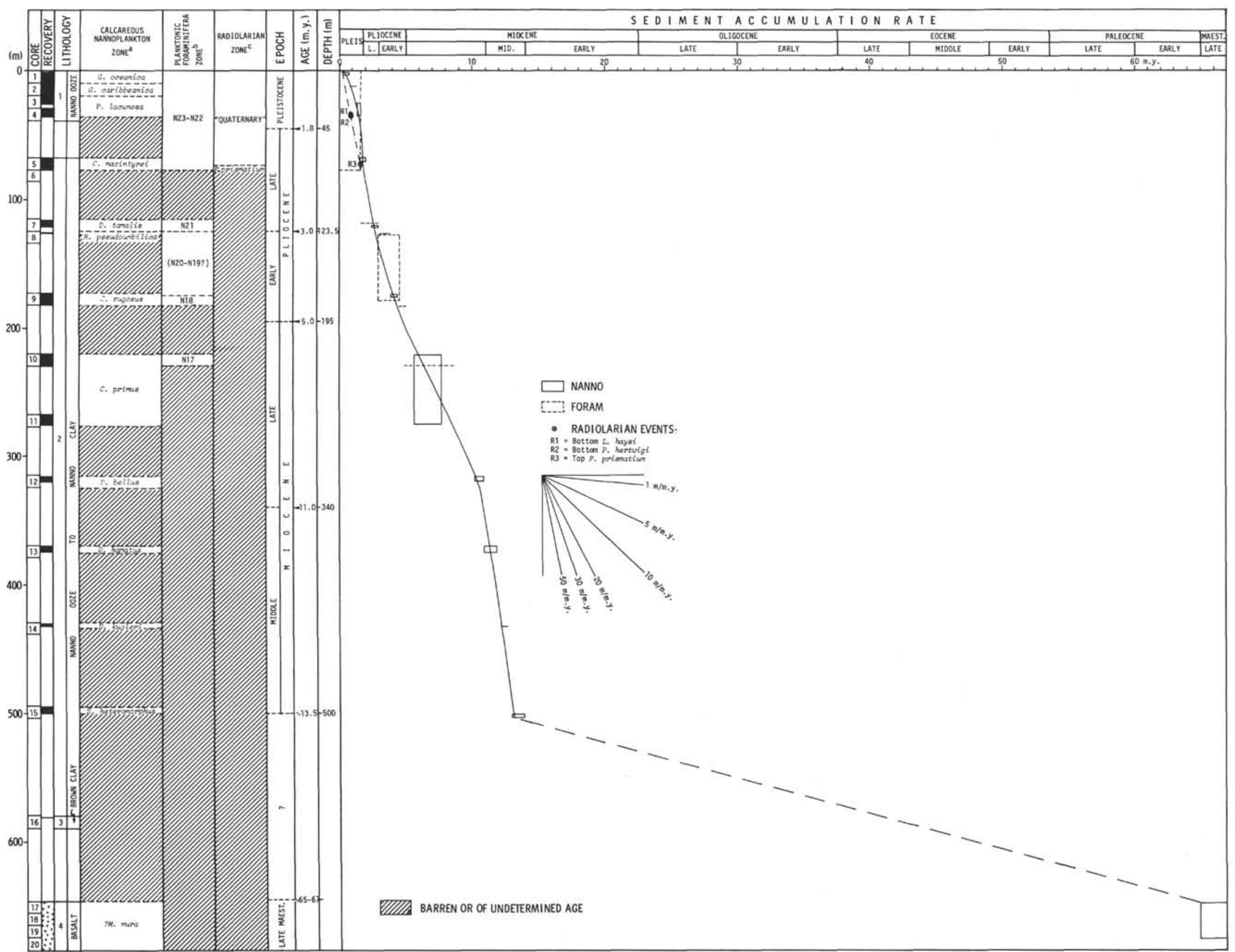

Figure 9. Planktonic biostratigraphy and sediment accumulation rate at Site 235. $a=$ Roth (this volume); Bukry (this volume), using Roth's zonation $b=$ Vincent, Frerichs, and Heiman (this volume). 
Discoaster bellus and D. hamatus zone, were both placed in unrecovered intervals on the basis of sedimentation rates. The lowest dated sediments above the basalt, at 500 meters (Core 15), are earliest middle Miocene in age (13-14 m.y., Sphenolithus heteromorphus Zone). The lower Pliocene and upper Miocene accumulation rates are 27.5 and 24.2 $\mathrm{m} / \mathrm{m}$.y., respectively, while the middle Miocene rate has a much higher value of $53.3 \mathrm{~m} / \mathrm{m} . \mathrm{y}$.

Sediments between 500 and 647 meters are of undetermined age; the only core recovered in this interval yielded no fossils. Sediment inclusions in the basalt $(662-665 \mathrm{~m})$, however, indicate a late Maestrichtian age (65-67 m.y. B.P.). The lower 147 meters of the sedimentary sequence thus correspond to an interval of time at least $51 \mathrm{~m} . \mathrm{y}$. in duration, indicating an average accumulation rate for this interval of $0.4 \mathrm{~m} / \mathrm{m} . \mathrm{y}$. This low value clearly indicates breaks in sedimentation during that interval.

\section{Central Western Indian Ocean}

\section{Geologic and Lithologic Setting}

Three sites were drilled in the central western Indian Ocean in the Mascarene Plateau/Central Indian Ridge/ Chagos-Laccadive Ridge complex area, a region extensively studied by Fisher et al. (1967, 1968, 1971). Site 236 is located in the outermost foothills southwest of the Carlsberg Ridge, $270 \mathrm{~km}$ northeast of the Seychelles Islands. This site lies on a smooth sea floor 60 miles north of magnetic Anomaly 28 , the oldest lineation of a magnetic anomaly pattern trending west-northwest, more or less paralleling the present or ancestral Carlsberg Ridge (Fisher et al., 1968, 1971; McKenzie and Sclater, 1971). Site 237 was drilled on the Mascarene Plateau in the saddle joining the granitic Seychelles Bank to the volcanic Saya de Malha Bank, in a fault-bounded region of nondescript magnetic patterns. Site 238 is located at the extreme northeast end of the Argo Fracture Zone, within a partly buried transformfault cleft crossing the seismically active and spreading Central Indian Ridge in an area where no magnetic interpretation is available.

Sites 236 and 238 reached basement at 305 and 500 meters respectively, while Site 237 was terminated short of basement of technical reasons at 693 meters. The sedimentary sequences recovered at the three locations are pelagic in nature and consist of nannofossil oozes in the Neogene (intercalated with clays in the lower and middle Miocene at Site 236), nannofossil chalks in the Oligocene, and nannofossil chalks with chert in the Eocene and Paleocene. The thick ( $340 \mathrm{~m})$ Paleocene section at Site 237 is strongly lithified and partly silicified and contains some glauconitic horizons.

At Sites 237 and 238 sediments are texturally sands in the late Neogene and become finer with age, while at Site 236 the sediments are fine-grained, with many intercalated thin coarse-grained layers. Calcium carbonate content varies from $0 \%$ to $95 \%$ at Site 236 and is greater than $85 \%$ at Site 238. Six, five, and three lithologic units were differentiated at Sites 236, 237, and 238, respectively, based on changes in the proportion of major components and in calcium carbonate content. A seventh unit was recognized at Site 236, and a fourth at Site 238, representing basaltic rocks with sediment inclusions.

\section{Abundance and Preservation of Microfossils}

Continuous coring (except for the lower $100 \mathrm{~m}$ at Site 237 where alternate joints were cored), with good recovery in the Oligocene and Neogene sections and poorer recovery in the cherty Paleocene and Eocene sequences, provided excellent material for planktonic biostratigraphic studies. Dissolution of calcareous components is common, however, in some parts of the sections, especially in the condensed lower Miocene and Oligocene series. Calcareous plankton is abundant throughout most of the sedimentary sequence at the three locations (except in the lower and middle Miocene clay horizons of Site 236), and siliceous microfossils are common in upper Neogene and Eocene sediments.

At Site 236, Quaternary to upper Eocene sediments contain moderately well preserved nannofossils, but foraminifera are poorly to moderately preserved with significant fragmentation. Foraminiferal preservation varies, however, depending on the lithology. The fine-grained ooze contains planktonic foraminifera which are more poorly preserved than those found in the coarse-grained ooze layers. The latter may be derived from transported sediments, a suggestion supported by variations in the relative abundance of benthonic species which constitute $10 \%$ or more of the foraminiferal populations in most of the horizons, but decrease to less than $1 \%$ in many layers. Radiolarians are common to abundant, and poorly to well preserved, in the upper Miocene through Pleistocene and in the Paleogene. They dominate the coarse fractions of lower Oligocene and upper Eocene sediments, but are absent in the lower and middle Miocene. Diatoms are common and well to moderately preserved in the upper 15 meters, but absent below. Fish remains are common in middle and lower Miocene and uppermost Oligocene sediments where calcium carbonate dissolution is pronounced and diluting components have been dissolved.

At Site 237 nannofossils are common throughout the sequence, well preserved in the Quaternary and Pliocene, and moderately preserved below. Secondary overgrowth increases toward the bottom of the section in the lower Paleocene. Foraminifera are abundant and well preserved in upper Neogene sediments and are common and poorly to moderately preserved in the lower Miocene, Oligocene, and upper and middle Eocene. In lower Eocene and Paleocene sediments, foraminiferal tests are often recrystallized and silicified, particularly in the lower part of the section. Planktonic species dominate the foraminiferal assemblages; benthonic species do not exceed $1 \%$ of the foraminiferal population except in some Paleocene horizons.

Calcareous nannoplankton is well to moderately well preserved throughout the section at Site 238. Foraminiferal preservation is similarly good throughout the late Neogene, although in some horizons they show a high degree of fragmentation. In older sediments foraminifera are moderately well preserved and less diversified, but show a lower degree of fragmentation; they are often of small size. Radiolarians are common to abundant and moderately to well preserved in the middle Miocene through Pleistocene sequence, but are absent below. Diatoms are common to abundant in the upper Miocene through Pleistocene section and are absent below; they are moderately to well preserved in the upper 215 meters and moderately to poorly preserved in the 215-293 meter interval. 
Stratigraphic Boundaries and Accumulation Rates

Site 236 (Figure 10)

The Pliocene/Pleistocene boundary was placed at the extinction of Discoaster brouweri about 3 meters below the initial appearance of Globorotalia truncatulinoides and the top of Pterocanium prismatium. The early/late Pliocene boundary based on foraminiferal data would lie in the upper part of Core 5, whereas the nannofossil evidence suggests that it should be placed between Core 3, Section 3 and Core 4, Section 1. The latter interpretation implies condensation of the late Pliocene. Because of this discrepancy between floral and faunal calcareous zonations and because reworking of older radiolarians and planktonic foraminifera is common in Pliocene assemblages, the late and early Pliocene were not differentiated.

The Miocene/Pliocene boundary was placed at the base of the N18, between the Ceratolithus rugosus and $C$. tricorniculatus zones. The $C$. acutus Zone was not recognized at this site. The middle/late Miocene boundary was placed at the Discoaster bellus/D. hamatus zonal boundary, although this level falls within N13. The boundary based on foraminiferal data, therefore, would lie slightly higher (between Core 13, Section 6 and Core 15, Section 3). A similar discrepancy was observed at Site 231 in the Gulf of Aden (Figure 5).

In contrast to upper Neogene (middle Miocene through Pleistocene) sediments, which accumulated at an average rate of $11.3 \mathrm{~m} / \mathrm{m} . y$., the lower Miocene, Oligocene, and upper Eocene series are very condensed. These accumulated at an average rate of $3.6 \mathrm{~m} / \mathrm{m} . \mathrm{y}$. Within that interval, epoch boundaries were placed on nannofossil data. These determinations are in good agreement with foraminiferal data, although precise foraminiferal boundary definitions were impossible in a number of intervals with mixed faunas.

A lacuna representing the entire middle Eocene occurs between Cores 28 and 29 (between the Discoaster barbadiensis and D. sublodoensis zones), and another hiatus of approximately $5 \mathrm{~m} . \mathrm{y}$. spans the Paleocene/Eocene boundary (Discoaster lodoensis/D. multiradiatus zones and P4/P7). The age of the oldest sediment immediately overlying basement at 305 meters is 57.58 m.y. B.P. (P4 and Discoaster mohleri zones). Lower Eocene sediments accumulated at approximately $12.6 \mathrm{~m} / \mathrm{m} . y$. , while upper Paleocene sediments accumulated at a slower rate $-5.3 \mathrm{~m} / \mathrm{m} . \mathrm{y}$.

Faunal assemblages of many horizons at this site include reworked older elements (radiolarians and foraminifera), often in such high proportions as to obscure the autochtonous component. This significant amount of reworking is likely related to the displacement of the coarse-grained ooze layers into the fine-grained autochtonous ooze.

\section{Site 237 (Figure 11)}

The Pliocene/Pleistocene boundary is not well defined because of an unrecovered interval near the boundary. Globorotalia truncatulinoides first occurs in Sample 3, CC, and the boundary was therefore drawn between Cores 3 and 4 (approximately $25 \mathrm{~m}$ ) below the unrecovered interval. The boundary as so defined implies the absence of the uppermost Pliocene. If the presence of $G$. truncatulinoides in Sample 3, CC is due to downhole contamination, however, and if a constant sedimentation rate is assumed for the Pleistocene and late Pliocene, then the Pliocene/Pleistocene boundary would lie at about 18 meters.

The early/late Pliocene boundary was placed at the base of N21 and the Discoaster tamalis Zone and the Miocene/ Pliocene boundary at the base of the Ceratolithus acutus Zone, which approximates the base of N18. The middle/ late Miocene boundary, set at the Discoaster bellus/D. hamatus boundary, falls within an interval of mixed foraminiferal faunas bounded by assemblages of N17 and N13 age. A slight discrepancy between the foraminiferal and nannofossil zonations in the middle Miocene is shown by the lower sedimentation rate curve drawn on the basis on foraminifera. A similar discrepancy was found at Site 238 (Figure 12). The early/middle Miocene boundary drawn between the Sphenolithus heteromorphus and Helicopontosphaera ampliaperta zones, lies between foraminiferal Zones N13 and N6. (Intermediate foraminiferal zones were not recognized but may be condensed between Core 17, Section 5 and Core 18, Section 2.)

A change in sedimentary regime, similar to that observed at Site 236, occurs at the early/middle Miocene boundary. Upper Neogene sediments accumulated at an average rate of $11.3 \mathrm{~m} / \mathrm{m}$.y., a value identical to the average rate at Site 236 for the same interval, while lower Miocene, Oligocene, and upper Eocene sequences are very condensed. The latter accumulated at an average rate of only $2 \mathrm{~m} / \mathrm{m} . \mathrm{y}$. The Oligocene and upper Eocene series are especially condensed $(1.4 \mathrm{~m} / \mathrm{m} . \mathrm{y}$. average), and a number of fossil zones in this interval were not observed.

The Oligocene/Miocene boundary was placed between the Discoaster druggii and Reticulofenestra abisecta zones; the foraminiferal zonation, however, indicates that the boundary should be placed somewhat higher. Below this level good agreement was found between foraminiferal and nannofossil zonations.

The late Eocene is extremely condensed and was recognized only in the lower part of Core 23 . The early/middle Eocene boundary was placed between the Chiasmolithus gigas and Discoaster sublodoensis zones, within an undifferentiated P10-P9 interval, and between the Theocampe mongolfieri and Buryella clinata radiolarian zones at about 320 meters (on the basis of sedimentation rates). The Paleocene/Eocene boundary, within the Bekoma bidarfensis radiolarian Zone, ${ }^{2}$ lies within an unrecovered interval, and on the basis of sedimentation rates falls at about 354 meters.

Between 43 and 49 m.y. B.P. (middle Eocene) and 53.5 and 57.6 m.y. B.P. (latest Paleocene, younger than the Discoaster mohleri/Heliolithus kleinpelli zonal boundary), sediments accumulated at an average rate of $17.4 \mathrm{~m} / \mathrm{m} . \mathrm{y}$. and $11.1 \mathrm{~m} / \mathrm{m} . y$. , respectively, while between 49 and 53.5 m.y. B.P. lower Eocene sediments accumulated at a reduced rate of $7.5 \mathrm{~m} / \mathrm{m} . \mathrm{y}$. A higher rate of $68.2 \mathrm{~m} / \mathrm{m} . \mathrm{y}$. was

\footnotetext{
${ }^{2}$ The author spent part of her life near the town of Bidart (southern France) from which the name Bekoma bidarfensis Riedel and Sanfilippo (1971) was derived, and would like to point out the lapsus calami involved in this species name.
} 


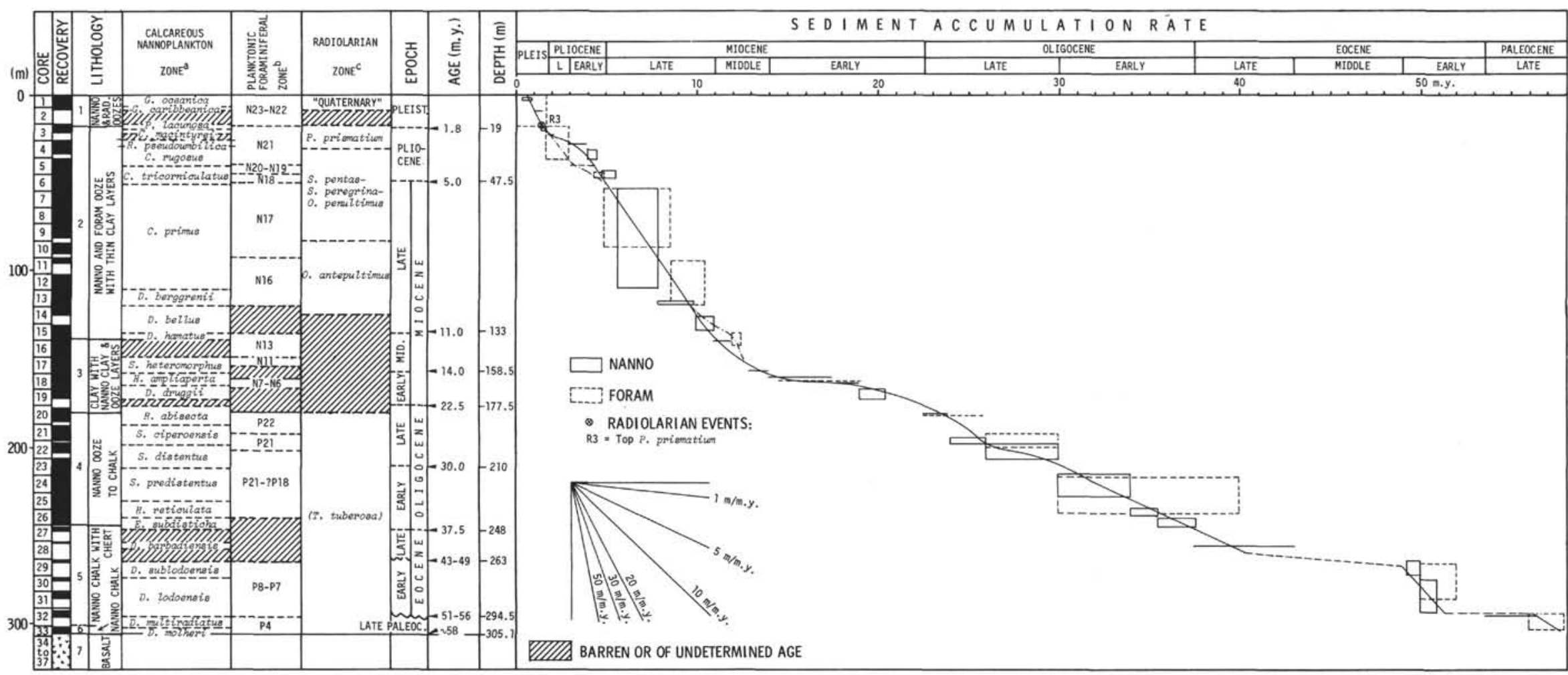

Figure 10. Planktonic biostratigraphy and sediment accumulation rate at Site 236. $a=$ Roth (this volume); Bukry (this volume), using Roth's zonation; $b=$ Vincent Frerichs, and Heiman (this volume); Heiman, Frerichs, and Vincent (this volume); $c=$ Sanfilippo and Riedel (this volume). 


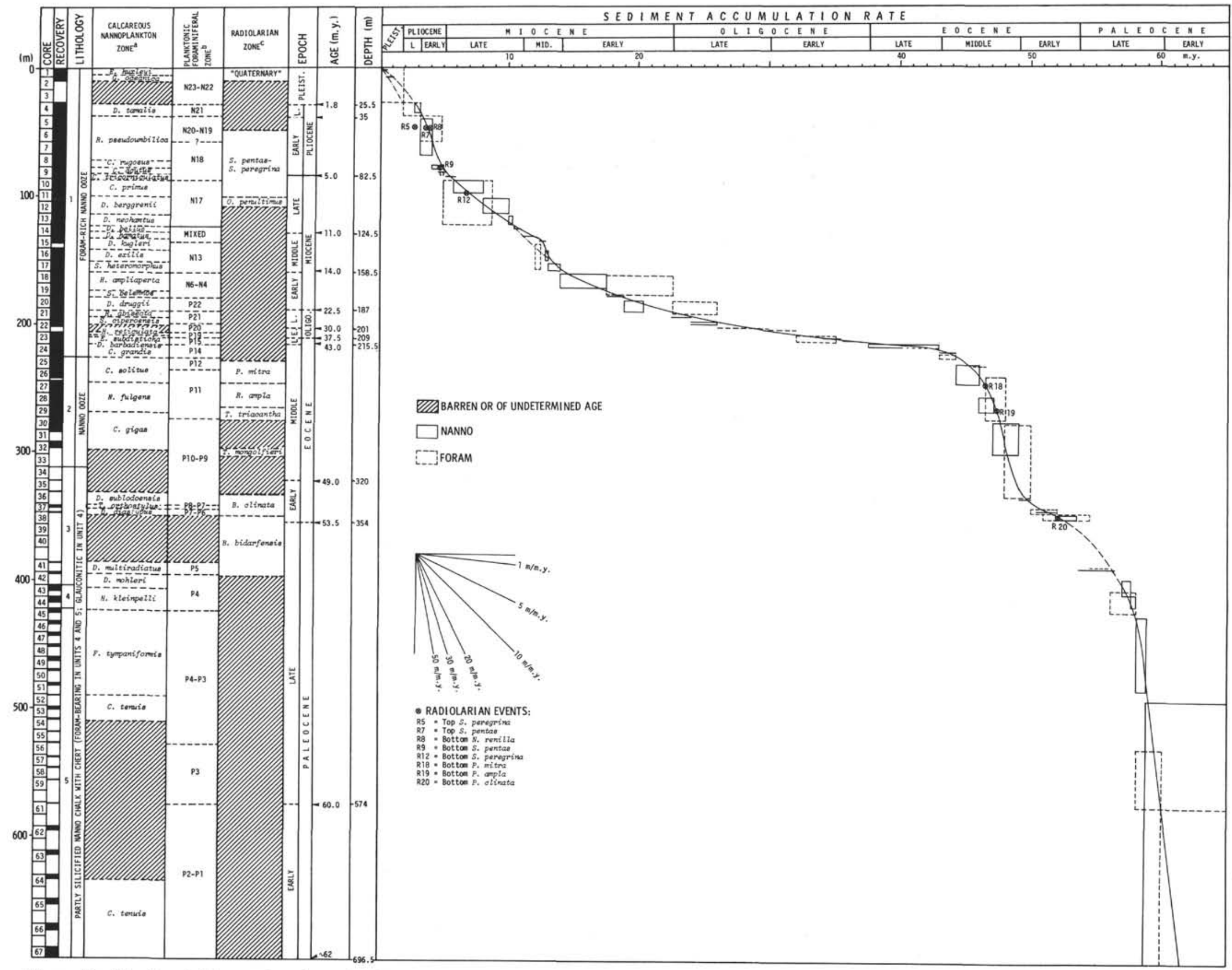
Figure 11. Planktonic biostratigraphy and sediment accumulation rate at Site 237. $a=$ Roth (this volume); $b=$ Vincent, Frerichs, and Heiman (this volume);
Heiman, Frerichs, and Vincent (this volume); Vincent, Gibson, and Brun (this volume). 
determined for the early late Paleocene (between 57.6 and 60 m.y., between the $D$. mohleri/H. kleinpelli and the P3/P2 boundaries).

The hole was terminated at 696.5 meters in sediments of early Paleocene age (Cruciplacolithus tenuis Zone and P1). If the accumulation rate of $68.2 \mathrm{~m} / \mathrm{m} . \mathrm{y}$. remained constant during the early Paleocene, then sediments at the bottom of the hole are approximately $62 \mathrm{~m} . \mathrm{y}$. old. If it is also assumed that about 100 meters of additional sediments are present between hole bottom and the igneous basement (Chapter 8, this volume), the age of the sediment/basement contact is approximately 63 m.y. B.P. (early Paleocene).

\section{Site 238 (Figure 12)}

The top of the sedimentary sequence (Core 1, Sections 1 to 4) includes mixed modern and reworked early Pleistocene and Pliocene faunas. The Pliocene/Pleistocene boundary is not well defined because an interval (between Core 4, Section 1 and Core 7, Section 1) with reworked sediments occurs at the boundary. The displaced material, which includes lower Pliocene and lower upper Pliocene microfossils (nannofossils, foraminifera, and radiolarians), is more probably reworked into younger Pliocene than into Pleistocene sediments because the Pleistocene species Globorotalia truncatulinoides, Lamprocyrtis haysi, and Pterocorys hertwigii are absent in this interval. The Pliocene/ Pleistocene boundary was therefore placed at the lowest occurrence of $G$. truncatulinoides, just above the reworked interval at about 38 meters (upper Core 4), a level slightly below the extinction horizon of Pterocanium prismatium. Some of the data, however, conflict with this interpretation. The first appearance of the radiolarian Theocorythium trachelium, which at other Leg 24 sites approximates the extinction level of $P$. prismatium, occurs considerably lower here (Core 11, Section 1). Early Pleistocene calcareous nannoplankton occurs in Core 6, Section 2 below the boundary (Bukry, this volume), and the diatom species Pseudoeunotia doliolus, known to evolve at the Pliocene/ Pleistocene boundary in the Pacific Ocean (Burckle, 1969; Schrader, 1973), first occurs here below the boundary (Core 6, Section 4). The diatom event, however, appears to be unreliable in the tropical Indian Ocean, because it occurs at different levels compared to radiolarian events (see discussion below).

The early/late Pliocene boundary, placed at the base of the Discoaster tamalis Zone, lies within N20-N19, and the Spongaster pentas and TID 10 zones; the Miocene/Pliocene boundary, at the base of $\mathrm{N} 18$ and the Ceratolithus acutus Zone is located within the Stichocorys peregrina and TID 13 zones. The early/late Miocene boundary, placed below the Discoaster bellus Zone, approximates the Ommatartus antepenultimus/Cannartus pettersoni Zone boundary and the base of TID 21 (within an interval of mixed foraminiferal faunas of questionable N17 age).

Slight discrepancies were observed between the nannofossil and foraminiferal zonations below the upper Miocene. Because of the dissolution of foraminiferal zonal markers in this part of the section, boundaries were drawn on nannofossil data. The early/middle Miocene was placed at the base of the Sphenolithus heteromorphus Zone, somewhat lower than is indicated by the foraminiferal and radiolarian zonations. The Oligocene/Miocene boundary was drawn at the base of the Triquetrorhabdulus carinatus Zone; the foraminiferal zonation, however, indicated that the boundary should be placed somewhat lower in the section. The sediments just above the basalt are latest early Oligocene in age (S. predistentus and P19 zones), approximately 32 m.y. old.

Sediment accumulation rates are higher at Site 238 than at Sites 236 and 237 for the equivalent intervals. They show, however, a similar change at the early/middle Miocene boundary. Sediments younger than $14 \mathrm{~m} . \mathrm{y}$. in age accumulated at an average rate of $25.9 \mathrm{~m} / \mathrm{m} . \mathrm{y}$. (a higher late Pliocene value of $44.6 \mathrm{~m} / \mathrm{m}$.y. results from the influx of displaced sediments at this time), while lower Miocene and Oligocene sediments accumulated only one-third as rapidly, at an average rate of $8.7 \mathrm{~m} / \mathrm{m} . \mathrm{y}$.

\section{REMARKS ON RADIOLARIAN EVENTS}

Sedimentation rates for the expanded hemipelagic sequences at Sites 232 and 233 serve as the basis for the age estimate of late Neogene horizons in this region. Pterocanium prismatium became extinct about one-half m.y. later than Discoaster brouweri in the Gulf of Aden, while Pterocorys hertwigii and Lamprocyrtis haysi first appeared slightly later, at approximately 0.8-0.9 m.y. B.P. These three radiolarian events occur in the same sequential order at Sites 235 and 238 as in the Gulf of Aden; in the equatorial Pacific, however, they do not occur consistently in the same sequential order. With these exceptions, there is good agreement (Table 4, and Figures 5 to 12) between the successions of Neogene radiolarian events in the tropical Indian Ocean and the equatorial Pacific.

As a result of displacement or reworking, a number of events occur out of their usual sequence at several sites of Leg 24. Stichocorys peregrina is probably reworked into younger sediments at Site 232, and the highest occurrence of this species seems to be too young to mark the Pterocanium prismatium/Spongaster pentas zonal boundary at this site. Reworking here is also indicated by the presence of the late Miocene form Stichocorys delmontensis in Pliocene assemblages. The oldest occurrence of Spongaster pentas is lower at both Sites 232 and 238 than its known evolutionary appearance elsewhere; this species ranges below the base of Pterocanium prismatium and overlaps Ommatartus antepenultimus at Site 232, and ranges lower than Acrobotrys tritubus at Site 238.

Among the radiolarian events which occur within the Spongaster pentas Zone the extinction level of Pterocanium audax, at about 3.2-3.5 m.y. B.P., occurs very slightly above the extinction of Spongaster pentas, and appears to be a reliable biostratigraphic event, while the earliest occurrence of Nephrospyris renilla appears to vary in time. Biostratigraphic results at Site 237 indicate that the Bekoma bidarfensis Zone spans the Paleocene/Eocene boundary.

\section{REMARKS ON TROPICAL INDIAN OCEAN DIATOM ZONATION}

The late Neogene diatom stratigraphy of the tropical Indian Ocean has been studied by Schrader (this volume) at Sites 238, 213, and 215. The last two sites, which are located on either side of the Ninetyeast Ridge (Figure 13) below the present $\mathrm{CCD}$, received pelagic siliceous ooze 


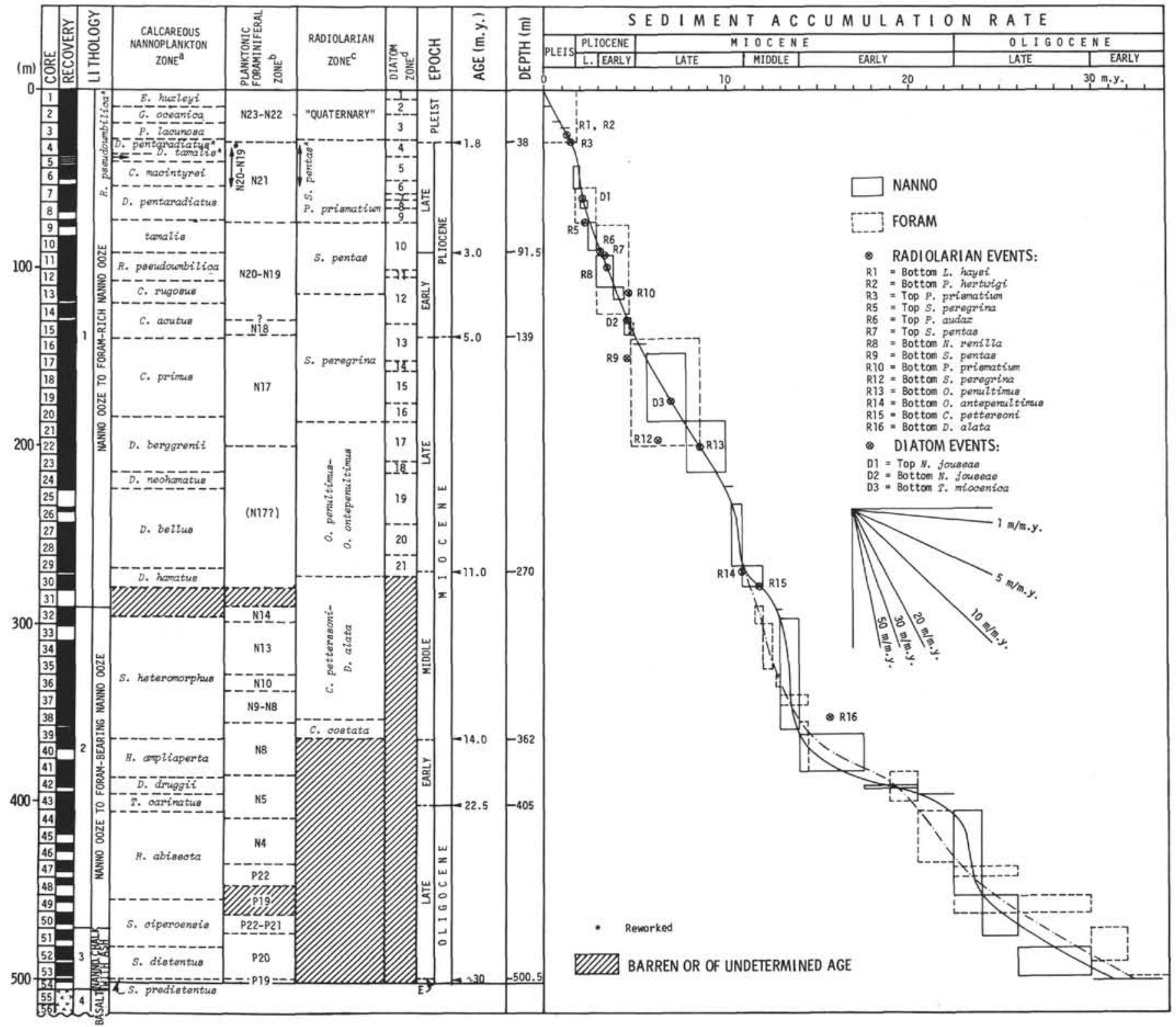

Figure 12. Planktonic biostratigraphy and sediment accumulation rate at Site 238. $a=$ Roth (this volume); $b=$ Vincent, Frerichs, and Heiman (this volume); Heiman, Vincent, and Frerichs (this volume); $c$ = Sanfilippo and Riedel (this volume); $d=$ Schrader (this volume).

during Pliocene and Pleistocene time which accumulated at an average rate of $10 \mathrm{~m} / \mathrm{m} . \mathrm{y}$. Schrader's sequence of tropical Indian Ocean Diatom (TID) zones is similar to that of Burckle (1972) for the equatorial Pacific, which has been calibrated to the paleomagnetic stratigraphy sequence (Hays et al., 1969; Burckle, 1972), but his TID zones are shorter and hence more numerous.

In order to evaluate the biostratigraphic reliability of diatoms events in the tropical Indian Ocean, the diatom zonation of Sites 238, 213, and 215 has been compared with the radiolarian zonations recognized at these sites and with the calcareous plankton zonation of Site 238 (Figure 14, Table 4). The TID zones have also been compared with the NPD (North Pacific Ocean Diatom) zones defined by
Schrader (1973) in the northeast Pacific and with their correlative calcareous plankton zones (Ingle, 1973; Bukry, 1973).

The TID 5/TID 6 boundary is defined by the evolutionary appearance of Pseudoeunotia doliolus, an event which in the Pacific approximates the Pliocene/Pleistocene boundary (base of the $P$. doliolus Zone of Burckle and of the NPD 4). Burckle (1969) showed that the lowest appearance of $P$. doliolus occurs during the Olduvai paleomagnetic event, approximately 1.7 to 1.8 m.y. in age, and Hays et al. (1969) noted that the radiolarian Pterocanium prismatium disappears just above the Olduvai event. In the Indian Ocean, however, Pseudocunotia doliolus first appears 4 meters above the last occurrence of Pterocanium prismatium at 
TABLE 4

Position of the Observed Neogene Radiolarian Zonal Boundaries and Selected Events Within Cores and Within Other Microfossil Zones at Various DSDP Sites in the Indian and Pacific Oceans

\begin{tabular}{|c|c|c|c|c|c|c|c|c|c|c|c|c|c|c|c|c|}
\hline \multirow{3}{*}{\multicolumn{2}{|c|}{$\begin{array}{l}\text { Radiolarian Zonal Boundaries and } \\
\text { Selected Radiolarian Eventsa, }\end{array}$}} & \multirow[b]{3}{*}{$\begin{array}{c}\mathrm{Agc} \\
(\mathrm{m} \cdot \mathrm{y} \cdot)^{\mathrm{c}}\end{array}$} & \multicolumn{5}{|c|}{ Leg 24} & \multirow{3}{*}{ 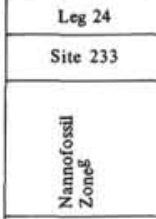 } & \multirow{2}{*}{\multicolumn{2}{|c|}{$\begin{array}{c}\text { Leg } 23 \\
\text { Site } 223\end{array}$}} & \multicolumn{6}{|c|}{ Leg 24} \\
\hline & & & \multicolumn{3}{|c|}{ Site 232} & \multicolumn{2}{|c|}{ Site 233} & & & & \multicolumn{3}{|c|}{ Site 235} & \multicolumn{3}{|c|}{ Site 237} \\
\hline & & & : & 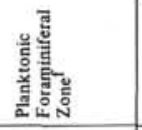 & 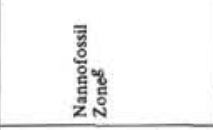 & 氹 & 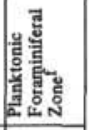 & & हुँ & 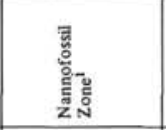 & 造 & 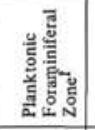 & 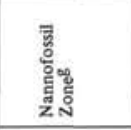 & है & 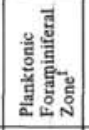 & 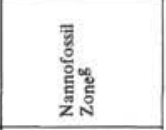 \\
\hline Bottom Lemprocyntis haysi & R1 & & $4.6-5.3$ & $\mathrm{~N} 23-\mathrm{N} 22$ & early G. oceanica & $4-3$ to $5-6$ & N21 & G. caribbeanica & & & $4-1$ to $5-1$ & $\mathrm{~N} 23-\mathrm{N} 22$ & $\begin{array}{l}\text { P. lacunosa. } \\
\text { C. macintyrei }\end{array}$ & & & \\
\hline Bottom Plerocorys hertwigi & R2 & & & & & 5.6 to 7.5 & N21 & $\begin{array}{l}\text { G. caribbeanica. } \\
\text { P. lacunosa }\end{array}$ & & & $4-4$ to $5-1$ & $\mathrm{~N} 23-\mathrm{N} 22$ & $\begin{array}{l}\text { P. lacunosa. } \\
\text { C. macintyrei }\end{array}$ & $2-1$ to $4-1$ & $\mathrm{~N} 23-\mathrm{N} 22$ & $\begin{array}{l}\text { G. oceanica to } \\
\text { D. ramalis }\end{array}$ \\
\hline $\begin{array}{l}\text { "Quaternary"|Pterocanium } \\
\text { prismartum zone bdry }\end{array}$ & R3 & $1.6-1.7$ & $5-3$ to $8-3$ & $\mathrm{~N} 22-\mathrm{N} 21$ & $\begin{array}{l}\text { G. oceanica to } \\
\text { P. lacunosa }\end{array}$ & 5.6 to 7.5 & N21 & \begin{tabular}{|l|} 
G. caribbeanica. \\
P. lacunosa
\end{tabular} & $3, \mathrm{CC}$ to $4-2$ & \begin{tabular}{|l|} 
G. caribbeanica to \\
D. pentaradiatus
\end{tabular} & $5-1$ to $5-6$ & $\mathrm{~N} 23-\mathrm{N} 22$ & $\begin{array}{l}\text { C. macintyrei } \\
\text { to } D \text {. tamalis }\end{array}$ & & & \\
\hline Bottom Theocorythium trachelium & R4 & & 5.3 to 8.3 & & $\begin{array}{l}\text { C. oceanica to } \\
\text { P. lacunosa }\end{array}$ & 5.6 to 8.4 & N21 & $\begin{array}{l}\text { C. caribbeanica. } \\
\text { P. lacunosa }\end{array}$ & & & & & & $2-1$ to $6-1$ & $\mathrm{~N} 23-\mathrm{N} 22$ & $\begin{array}{l}\text { G. oceanica to } \\
\text { D. tamalis } \\
\end{array}$ \\
\hline $\begin{array}{l}\text { P. prismatium/Spongester pentes } \\
\text { zone bdry }\end{array}$ & R5 & $2.5 \cdot 2.6$ & $4-6$ to $5-3$ & $\mathrm{~N} 23-\mathrm{N} 22$ & G. oceanica & $16-6$ to $18-5$ & N21 & D. pentaradiafus & S, CC to 6-2 & $\begin{array}{l}\text { D. tamalis. } \\
\text { D. assymetricus }\end{array}$ & & & & $5-1$ to $6-1$ & N20-N19 & R. pseudoumbilica \\
\hline Top Prerocantum audex & R6 & & $16-3$ to $17-3$ & Late N20-N19 & $\begin{array}{l}\text { D. tamelis/ } \\
\text { R. pseudoumbilica bdry }\end{array}$ & below 7A-5 & \begin{tabular}{|l|} 
N21 or \\
older
\end{tabular} & $\begin{array}{l}\text { D. tamalis or } \\
\text { oider }\end{array}$ & & & & & & 5-1 to $6-1$ & N20-N19 & R. pseudoumbilica \\
\hline Top S. pentas & R7 & 3.5 & $17-3$ to $18-3$ & N20-N19 & R. pseudoumbilica & & & & 4. CC to 5-2 & $\begin{array}{l}\text { D. pentaradiatus. } \\
\text { D. tamalis }\end{array}$ & & & & $5-1$ to $6-1$ & $\mid \mathrm{N} 20-\mathrm{N} 19$ & R. pseudoumbilica \\
\hline Bottom Nephrospyris renilla & R8 & & $15-5$ to $16-3$ & Late N20-N19 & D. tamalis & 106 to 11.6 & N21 & C. macintyrei & & & & & & 6-1 to 8-1 & $\mathrm{N} 20-\mathrm{N} 19$ & R. pseudoumbilica \\
\hline Bottom S pentes & R9 & 4.5 .4 .6 & $19 \mathrm{~A}-1$ to $20 \mathrm{~A}-1$ & N18-N17 & $\begin{array}{l}\text { c. tricorniculatus/ } \\
\text { c. primus bdry }\end{array}$ & & & & $6, \mathrm{CC}$ to 7.2 & $\begin{array}{l}\text { D. assymetricus } \\
\text { to } D \text {. berggrenti }\end{array}$ & & & & $9-1$ to $10-1$ & N18 & C. rugosus \\
\hline $\begin{array}{l}\text { S. pentas/Stichocorys peregrina } \\
\text { zone bdry }\end{array}$ & R10 & 4.8 & $6 \mathrm{~A}-1$ to $7 \mathrm{~A}-1$ & $\mathrm{~N} 20-\mathrm{N} 19$ & R. pseudoumbilice & & & & $6, \mathrm{CC}$ to 7.2 & \begin{tabular}{|l|} 
C. acutus to \\
D. berggrenii \\
\end{tabular} & & & & & & \\
\hline Top Ommatartus antepenultimus & $R 11$ & 5.7 & $18 \mathrm{~A}-2$ to $19 \mathrm{~A}-1$ & & $\begin{array}{l}\text { Earliest } \\
\text { C. tricorniculatus }\end{array}$ & & & & $11-5$ to $11-6$ & D. berggrenii & & & & & & \\
\hline $\begin{array}{l}\text { S. peregrina/Ommatartus } \\
\text { penultimus zone bdry }\end{array}$ & $\mathrm{R} 12$ & $6.2-6.3$ & below $21 \mathrm{~A}-2$ & & & & & & 8. CC to 9-1 & D. berggrenï & & & & $\mid 11-1$ to $12-1 \mid$ & N17 & $\begin{array}{l}\text { C. primus/ } \\
\text { D. berggrenil bdry }\end{array}$ \\
\hline $\begin{array}{l}\text { o. penultimus/O. antepenultimus } \\
\text { zone bdry }\end{array}$ & $R 13$ & $8.6-8.7$ & & & & & & & $11-6$ to $11 . \mathrm{CC}$ & D. berggrenii & & & & & & \\
\hline $\begin{array}{l}\text { O. antepenultimus/cannetartus } \\
\text { petterssoni zone bdry }\end{array}$ & R14 & call & & & & & & & 18.4 to $18-5$ & $\begin{array}{l}\text { D. neohamatus. } \\
\text { D. hamatus }\end{array}$ & & & & & & \\
\hline $\begin{array}{l}\text { C. petterssoni/Dorcadospyris alata } \\
\text { zone bdry }\end{array}$ & R15 & ca 12 & & & & & & & & & & & & & & \\
\hline $\begin{array}{l}\text { D. alata/calocycletta costata } \\
\text { zone bdry }\end{array}$ & R16 & ca 16 & & & & & & & & & & & & & & \\
\hline $\begin{array}{l}\text { C. costata/calocycletta virginis } \\
\text { zone bdry }\end{array}$ & R17 & ca 18 & & & & & & & & & & & & & & \\
\hline \multicolumn{8}{|c|}{$\begin{array}{l}\text { aZonation of Riedel and Sanfilippo (1971). } \\
\text { bR1, R2... events as shown on Figures } S \text { to } 12 \text {. } \\
\text { crheyer and Hammond } 1(194) \text {. } \\
\text { dGiven are the pair of core sections between which events or zone boundaries occur. }\end{array}$} & \multicolumn{9}{|c|}{$\begin{array}{l}\text { hNigrini (this volume). } \\
\text { iBukry (1974). }\end{array}$} \\
\hline
\end{tabular}


TABLE 4 - Continued

\begin{tabular}{|c|c|c|c|c|c|c|c|c|c|c|c|c|c|c|c|}
\hline \multirow{3}{*}{\multicolumn{2}{|c|}{$\begin{array}{l}\text { Radiolarian Zonal Boundaries and } \\
\text { Selected Radiolarian Eventsa", }\end{array}$}} & \multirow{2}{*}{\multicolumn{4}{|c|}{$\begin{array}{l}\text { Leg } 24 \\
\text { Site } 238\end{array}$}} & \multicolumn{3}{|c|}{ Leg 22} & \multicolumn{7}{|c|}{$\operatorname{Leg} 22$} \\
\hline & & & & & & \multicolumn{2}{|c|}{ Site 215} & \multirow{2}{*}{ 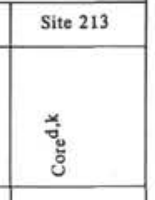 } & \multirow{2}{*}{ 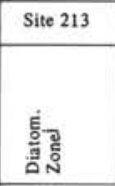 } & \multicolumn{3}{|c|}{ Site 214} & \multicolumn{3}{|c|}{ Site 216} \\
\hline & & 遌 & 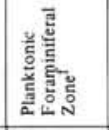 & 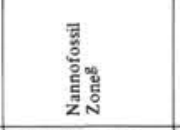 & 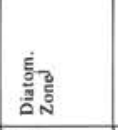 & 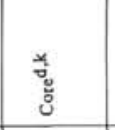 & 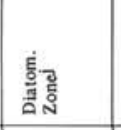 & & & 范 & 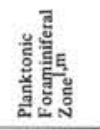 & 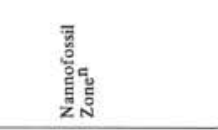 & 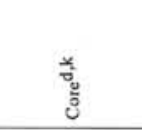 & 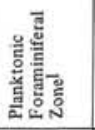 & 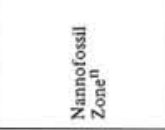 \\
\hline Bottom Lamprocyrtis haysi & R1 & $3-1$ to $3-6$ & $\mathrm{~N} 22$ & \begin{tabular}{|l|} 
G. oceanica to \\
P. lacunosa
\end{tabular} & TiD 3 & & & & & & & & & & \\
\hline Bottom Pterocorys hertwigi & $\mathrm{R} 2$ & $3-1$ to 6-1 & $\mathrm{N} 22-\mathrm{N} 21$ & $\begin{array}{l}\text { G. oceanica to } \\
\text { C. macintyrei }\end{array}$ & $\begin{array}{l}\text { TiD } 3 \text { to } \\
\text { TiD 5 }\end{array}$ & & & & & & & & & & \\
\hline $\begin{array}{l}\text { "Quaternary" "Pterocanium } \\
\text { prismatium zone bdry }\end{array}$ & R3 & $3-6$ to $4-1$ & $\begin{array}{l}\mathrm{N} 22 / \mathrm{N} 21 \\
\text { ddry }\end{array}$ & \begin{tabular}{|l|} 
P. lacunoso to \\
D. pentaradiatus
\end{tabular} & \begin{tabular}{|l|} 
TiD $3 /$ \\
TiD 4 bdry \\
\end{tabular} & 1.4 to 1.5 & \begin{tabular}{|l|} 
TiD 4 $4 /$ \\
TiD s bdry
\end{tabular} & $2-3$ to $2-4$ & TiD 6 & $2, \mathrm{CC}$ to 3.2 & $\mathrm{~N} 23-\mathrm{N} 22$ & P. lacunosa & & & \\
\hline $\begin{array}{l}\text { Bottom Theocorythium } \\
\text { trachelium }\end{array}$ & R4 & $11-1$ to $11-6$ & N20-N19 & R. pseudoumbitica & TiD 10 & 1, CC to $2-1$ & $\begin{array}{l}\text { TiD } 1 \text { to } \\
\text { TiD } 4\end{array}$ & $3-3$ to $3, \mathrm{CC}$ & TiD 7 & 36 to $3, \mathrm{CC}$ & $\mathrm{N} 21$ & D. brotweri & & & \\
\hline $\begin{array}{l}\text { P. prismatium/Spongaster } \\
\text { pentas zone bdry }\end{array}$ & RS & $8-2$ to 9.1 & \begin{tabular}{|l|} 
N21/N20. \\
N19 bdry
\end{tabular} & \begin{tabular}{|l|} 
D. pentaradiatus/ \\
D. tamalis bdry
\end{tabular} & TiD 9 & $2-1$ to $2, \mathrm{CC}$ & \begin{tabular}{|l} 
earliest \\
TiD 5
\end{tabular} & 3, CC to 4-2 & $\begin{array}{l}\text { TiD } 71 \\
\text { TiD } 8 \text { bdry }\end{array}$ & $5-1$ to 5.3 & $\mathrm{~N} 20-\mathrm{N} 19$ & D. Surculus & & & \\
\hline Top Pterocantum cudax & R6 & $10-1$ to $11-6$ & $\mathrm{~N} 20-\mathrm{N} 19$ & D. temalis & TiD 10 & & & & & & & & & & \\
\hline Top S. pentas & R7 & & & & & $3, \mathrm{CC}$ to $4-1$ & TiD 9 & $4, \mathrm{CC}$ to $5, \mathrm{CC}$ & TiD 11 & $6 \cdot 2$ to 6.4 & N20-N19 & $\begin{array}{l}\text { D. Surculus/ } \\
\text { R. pseudoumbilica bdry }\end{array}$ & & & \\
\hline $\begin{array}{l}\text { Bottom Nephrospyris } \\
\text { renilla }\end{array}$ & R8 & $11-6$ to 12.1 & $\mathrm{~N} 20 \mathrm{~N} 19$ & R. pseudoumbilica & TiD 11 & & & & & & & & & & \\
\hline Bottom S. pentes & R9 & $17-1$ to $17-6$ & N17 & C. primus & $\begin{array}{l}\text { TiD } 13 \cdot \\
\text { TiD } 14\end{array}$ & $4-3$ to 4.4 & $\begin{array}{l}\text { TiD } 9 / \\
\text { TiD } 10 \text { bdry }\end{array}$ & 6.5 to 6.6 & $\begin{array}{l}\text { Late } \\
\text { TiD } 12\end{array}$ & $8, \mathrm{CC}$ to $9-1$ & N19 & $\begin{array}{l}\text { R. pseudoumbilica } \\
\text { to } C \text {. nugosus }\end{array}$ & & & \\
\hline $\begin{array}{l}\text { S. pentas/Stichocorys } \\
\text { peregrina zone bdry }\end{array}$ & R10 & 13.1 to 13.5 & $\mathrm{~N} 20-\mathrm{N} 19$ & C. rugosus & TiD 12 & 5-3 to $5, \mathrm{CC}$ & $\begin{array}{l}\text { TiD } 12 / \\
\text { TiD } 13 \text { bdry }\end{array}$ & 74 to $7, \mathrm{CC}$ & $\begin{array}{l}\text { TiD 13- } \\
\text { TiD } 14\end{array}$ & $9-6$ to $9, \mathrm{CC}$ & $\begin{array}{l}\text { Early } \\
\text { N19 }\end{array}$ & C. rugosus & & & \\
\hline $\begin{array}{l}\text { Top Ommatertus } \\
\text { antepenultimus }\end{array}$ & R11 & & & & & & & & & & & & & & \\
\hline $\begin{array}{l}\text { S. peregrina/Ommatartus } \\
\text { penultimus zone bdry }\end{array}$ & R12 & $20-6$ to $21-1$ & N17 & D. berggrenii & $\begin{array}{l}\text { TiD } 16 / \\
\text { TiD } 17 \text { bdry }\end{array}$ & & & & & $13-3$ to $13-5$ & N17 & $\begin{array}{l}\text { D. quinqueramus/ } \\
\text { D. neohamatus bdry }\end{array}$ & & & \\
\hline $\begin{array}{l}\text { O. penultimus } / O \text {. } \\
\text { antepenultimus zone bdry }\end{array}$ & R13 & 22.1 to 22.6 & N17 & D. berggrenï & TiD 17 & & & & & $14, \mathrm{CC}$ to $15-2$ & $\begin{array}{l}\mathrm{N} 17 \text { to } \\
\mathrm{N} 16\end{array}$ & D. neohamatus & $1 \mathrm{~A}, \mathrm{CC}$ to $2 \mathrm{~A} \cdot 1$ & N17 & D. neohamatus \\
\hline $\begin{array}{l}\text { O. antepenuitimus/canna. } \\
\text { tartus petterssoni zone bdry }\end{array}$ & $\mathrm{R} 14$ & $\mid 30-2$ to $30-6$ & \begin{tabular}{|l}
$\mathrm{N} 17$ \\
$\mathrm{~N} 14$
\end{tabular} & D. lamarus & & & & & & $16,0 \mathrm{C}$ to 17.1 & $\begin{array}{l}\text { N16/N15 } \\
\text { bdry }\end{array}$ & D. neohamatus & $2 \mathrm{~A}, \mathrm{CC}$ to $3 \mathrm{~A}-1$ & N16 & $\begin{array}{l}\text { D. neohamatus } \\
\text { to } C \text {. coalitus }\end{array}$ \\
\hline $\begin{array}{l}\text { C. petterssoni/Dorcadospyris } \\
\text { alata zone bdry }\end{array}$ & $R 15$ & $30-6$ to $32-1$ & \begin{tabular}{|l|l|} 
N17 to to \\
N14
\end{tabular} & $\begin{array}{l}\text { D. hametus to } \\
\text { D. exilis }\end{array}$ & & & & & & 18.2 to 18.3 & $\mathrm{~N} 14$ & C. coalitus & $3 \mathrm{~A}, \mathrm{CC}$ to $4 \mathrm{~A}-2$ & $\begin{array}{l}\mathrm{N} 14 \text { ? to } \\
\mathrm{N} 13\end{array}$ & $\begin{array}{l}\text { C. coatitus } \\
\text { D. exilis }\end{array}$ \\
\hline $\begin{array}{l}\text { D. alata/calocyclette costata } \\
\text { zone bdry }\end{array}$ & R16 & $38-6$ & N8 & S. heteromorphus & & & & & & & & & SA-S to $5 \mathrm{~A}, \mathrm{CC}$ & N9-N8 & $\begin{array}{l}\text { D. exilis. } \\
\text { S. heteromorphus }\end{array}$ \\
\hline $\begin{array}{l}\text { C. costata/calocycletta } \\
\text { virginis zone bdry }\end{array}$ & R17 & & & & & & & & & & & & & & \\
\hline $\begin{array}{l}\text { aZonation of Riedel and Sanfil } \\
\text { bR1, R2... events as shown } \\
\text { dGiven are the pair of core sec } \\
\text { boundaries occur. } \\
\text { eSanfilippo and Riedel (this vo }\end{array}$ & $\begin{array}{l}\text { filippo ( } \\
\text { in on Fi } \\
\text { ictions b } \\
\text { volume). }\end{array}$ & $\begin{array}{l}(1971) \\
\text { igures } 5 \text { to } 12 \text {. } \\
\text { between which }\end{array}$ & he & $\begin{array}{l}\text { fVince } \\
\text { gRoth } \\
\text { ISchrad } \\
\text { k Johns }\end{array}$ & $\begin{array}{l}\text { nt, Frerichs, } \\
\text { (this volume): } \\
\text { der (this volum } \\
\text { son (1974). }\end{array}$ & $\begin{array}{l}\text { and Heiman (t } \\
\text { : Bukry (this } \\
\text { me). }\end{array}$ & $\begin{array}{l}\text { this volume). } \\
\text { volume), using }\end{array}$ & g Roth's zonation. & $\begin{array}{l}\text { IBerggren, } \\
\text { mMcGowr } \\
\text { nGartner ( }\end{array}$ & and Poor & & & & & \\
\hline
\end{tabular}


TABLE 4 - Continued

\begin{tabular}{|c|c|c|c|c|c|c|c|c|}
\hline \multirow{3}{*}{\multicolumn{2}{|c|}{$\begin{array}{l}\text { Radiolarian Zonal Boundaries and } \\
\text { Selected Radiolarian Events } \text { sat, }^{\text {b }}\end{array}$}} & \multicolumn{3}{|c|}{ Leg 22} & \multicolumn{3}{|c|}{ Leg 8} & \multirow{3}{*}{$\begin{array}{c}\text { Leg } 9 \\
\text { Site } 77 \mathrm{~B} \\
\\
\stackrel{\circ}{\circ} \\
\stackrel{\circ}{0}\end{array}$} \\
\hline & & \multicolumn{3}{|c|}{ Site 217} & \multicolumn{3}{|c|}{ Site 73} & \\
\hline & & : & 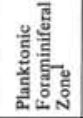 & 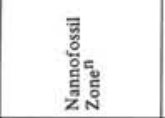 & 递 & 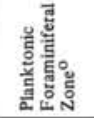 & 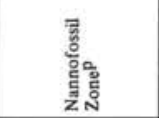 & \\
\hline Bottom Lamprocyrtis haysi & R1 & & & & $4-2$ to $4-6$ & N21 & $\begin{array}{l}\text { C. macintyrei } \\
\text { to } C \text {. nugosus }\end{array}$ & $2-6$ to $3-1$ \\
\hline Bottom Pterocorys hertwigi & $\mathrm{R} 2$ & & & & $3-6$ to $4-2$ & N21 & G. dioronicoides & $2-6$ to $3-1$ \\
\hline $\begin{array}{l}\text { "Quaternary"/Pterocanium } \\
\text { prismathim zone bdry }\end{array}$ & R3 & & & & $3-4$ to $3-6$ & $\begin{array}{l}\mathrm{N} 22 ! \\
\mathrm{N} 21 \text { bdry }\end{array}$ & G. doronicoides & $2-6$ to 3-1 \\
\hline $\begin{array}{l}\text { Bottom Theocorythium } \\
\text { trachelium }\end{array}$ & R4 & & & & 36 to $4-2$ & $\mathrm{~N} 21$ & G. doronicoides & 3.1 to 3.3 \\
\hline $\begin{array}{l}\text { P. prismattum/Spongaster } \\
\text { pentas zone bdry }\end{array}$ & R5 & & & & $5-3$ to $5-6$ & $\begin{array}{l}\mathrm{N} 21 / \mathrm{N} 20- \\
\mathrm{N} 19 \text { bdry }\end{array}$ & $\begin{array}{l}\text { C. macintyrei } \\
\text { to } C \text {. nugosus }\end{array}$ & $3-3$ to $3-5$ \\
\hline Top Pterocentum audax & R6 & & & & $6-1$ to $6-3$ & $\mathrm{~N} 20-\mathrm{N} 19$ & $\begin{array}{l}\text { C. macintyrei } \\
\text { to } C \text {. rugosus }\end{array}$ & 4.3 to $4-6$ \\
\hline Top $S$. pentes & R7 & & & & $5-6$ to $6-1$ & $\mathrm{~N} 20-\mathrm{N} 19$ & $\begin{array}{l}\text { C. macintyrei } \\
\text { to } C . \text { nugosus }\end{array}$ & $4-3$ to $5-1$ \\
\hline $\begin{array}{l}\text { Bottom Nephrospyris } \\
\text { renilla }\end{array}$ & R8 & & & & 7.3 to 7.6 & $\begin{array}{l}\text { N20-N19/ } \\
\text { N18 bdry }\end{array}$ & $\begin{array}{l}\text { C. rugosus to } \\
\text { C. tricornicularus }\end{array}$ & 7.1 to 7.2 \\
\hline Bottom $S$. pentas & R9 & & & & below 84 & $\begin{array}{l}\text { N18 or } \\
\text { below }\end{array}$ & $\begin{array}{l}\text { C. tricorniculatus } \\
\text { or below }\end{array}$ & $9-4$ to $9-6$ \\
\hline $\begin{array}{l}\text { S. pentas/Stichocorys } \\
\text { peregrina zone bdry }\end{array}$ & R10 & & & & & & & \\
\hline $\begin{array}{l}\text { Top Ommatartus } \\
\text { antepenultimus }\end{array}$ & R11 & & & & & & & \\
\hline $\begin{array}{l}\text { S. peregrina/Ommatartus } \\
\text { penultimus zone bdry }\end{array}$ & $R 12$ & 3-1 to $3, \mathrm{CC}$ & $\begin{array}{l}\text { N17 to } \\
\text { N16 }\end{array}$ & D. quinqueramus & & & & \\
\hline $\begin{array}{l}\text { o. penultimus/O. } \\
\text { antepenultimus zone bdry }\end{array}$ & R13 & $3, \mathrm{CC}-4, \mathrm{CC}$ & $\begin{array}{l}\text { N16 to } \\
\text { N5 }\end{array}$ & $\begin{array}{l}\text { D. quinqueramus. } \\
\text { D. neohamatus }\end{array}$ & & & & \\
\hline $\begin{array}{l}\text { O. antepenultimus/canna. } \\
\text { tartus petterssoni zone bdry }\end{array}$ & R14 & & & & & & & \\
\hline $\begin{array}{l}\text { C. petterssoni/Dorcadospyris } \\
\text { alata zone bdry }\end{array}$ & R15 & & & & & & & \\
\hline $\begin{array}{l}\text { D. alata/calocycletta costata } \\
\text { zone bdry }\end{array}$ & R16 & & & & & & & \\
\hline $\begin{array}{l}\text { C. costara/calocycletta } \\
\text { virginis zone bdry }\end{array}$ & R17 & & & & & & & \\
\hline
\end{tabular}

kJohnson (1974).

Perggren, Lohmann, and Poore (1974).

OBeckmann (1971).
PBukry (1971).

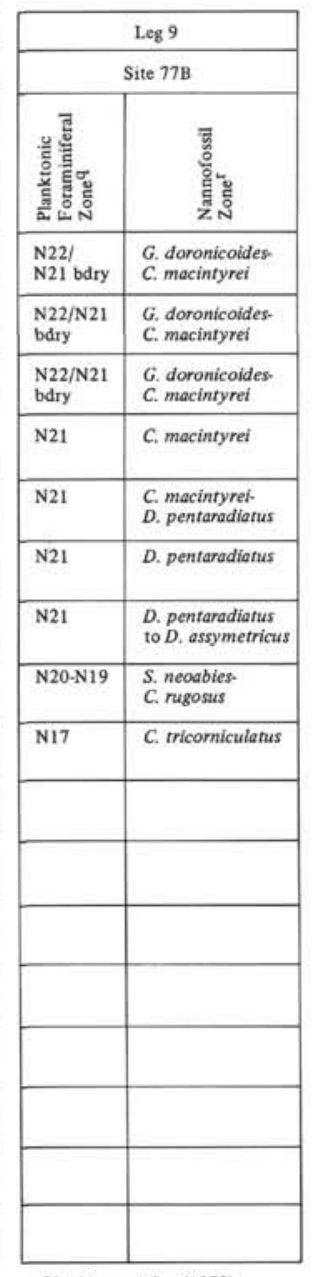

qJenkins and Orr (1972).

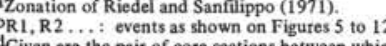




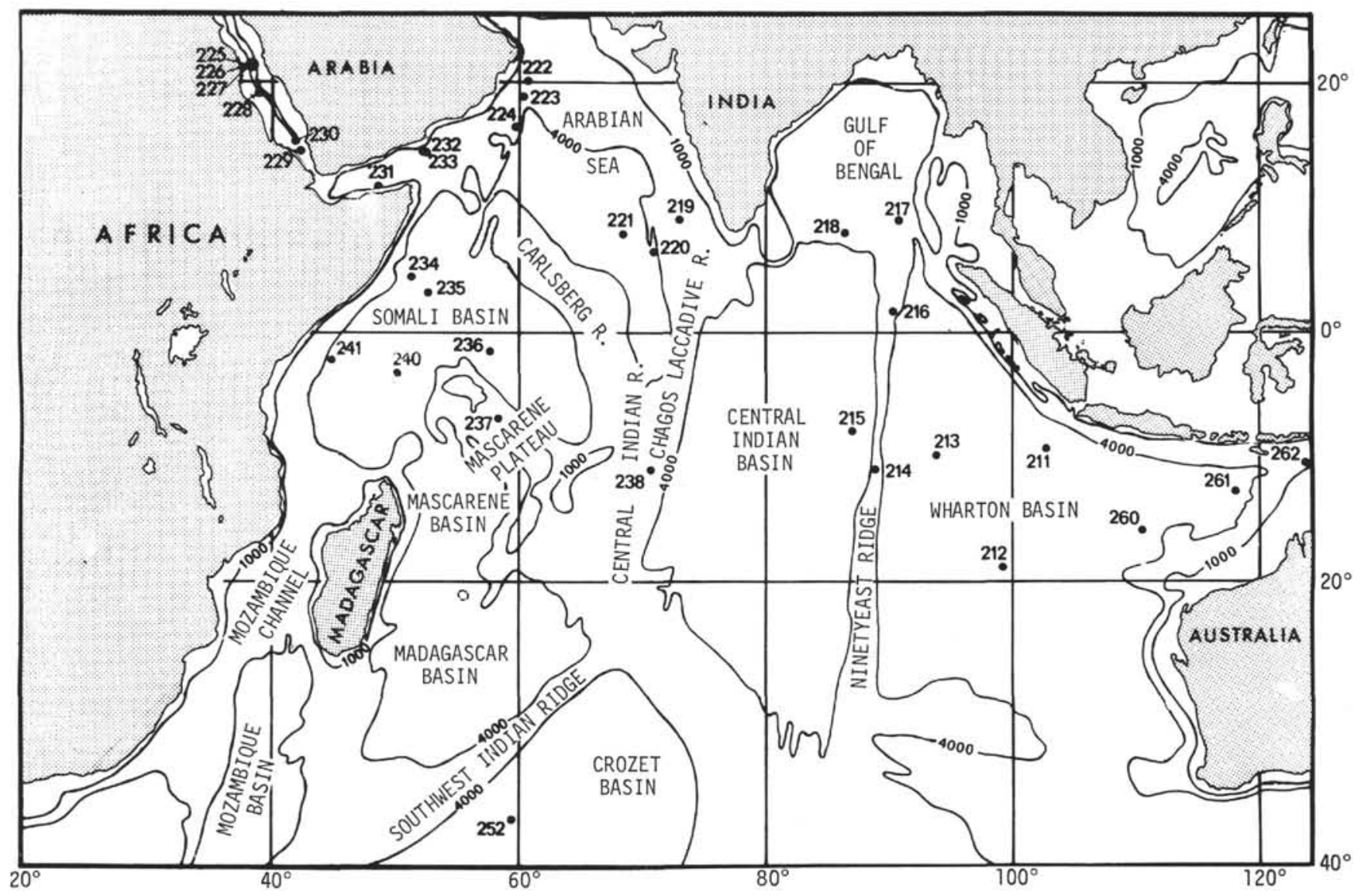

Figure 13. DSDP sites in the Red Sea and Indian Ocean north of $20^{\circ} \mathrm{S}$.

Site 213 , but well below it (11 and $22 \mathrm{~m}$, respectively) at Sites 215 and 238 .

The TID 7/TID 8 boundary is defined by the extinction of Nitzschia jouseae. This event falls within the middle part of the Rhizosolenia praebergonii Zone of Burckle(1972), in the middle Gauss Magnetic Epoch (about 2.4 m.y. B.P.). It should therefore approximate the Stichocorys peregrina extinction datum ( $P$. prismatium/Spongaster pentas Zone boundary), one of the most reliable late Pliocene datum planes, which occurs consistently in the latest Gauss (Theyer and Hammond, 1974). The base of TID 7 correlates with the $P$. prismatium $/ S$. pentas Zone boundary at Site 213 , but is slightly older at Site 215 and slightly younger at Site 238. The TID 7/TID 8 boundary, equivalent to the NPD 7/NPD 8 boundary, falls within the Discoaster brouweri nannofossil Zone in both the Indian and northeast Pacific oceans, but occurs within N21 at Site 238 and within N20-N19 at Site 173.

The TID 12/TID 13 boundary is defined by the first appearance of Nitzschia jouseae, an event which also defines the base of the $N$. jouseae Zone of Burckle (1972) and correlates with the " $c_{1}$ " event of the Gilbert reversed Epoch, approximately 4.3 m.y. B.P. This boundary should therefore occur just above the $S$. pentas first appearance datum (within the early $S$. pentas Zone of Riedel and Sanfilippo), which correlates with the Gilbert " $c_{2}$ " event, 4.5-4.6 m.y. in age (Theyer and Hammond, 1974), and fall slightly above the Miocene/Pliocene boundary, approximately 5 m.y. B.P. (Berggren and Van Couvering, 1974). In fact, the TID 12/TID 13 boundary lies 5 and 9 meters below the $S$. pentas datum at Sites 213 and 215 , respectively (Johnson, 1974). At Site 238 this diatom event is located even lower, below the $S$. pentas Zone, but radiolarians events here may be biostratigraphically unreliable; the $S$. pentas $/ S$. peregrina Zone boundary occurs above the Miocene/Pliocene boundary as defined by calcareous plankton events, and $S$. pentas first appears in the late Miocene. The base of TID 12 at Site 238 is located slightly above the base of N18 and the Ceratolithus acutus Zone, the Miocene/ Pliocene boundary as recognized here. The TID 12/TID 13 and the NPD 10/NPD 11 boundaries are equivalent and the latter also approximates the base of N18.

The TID 15/TID 16 boundary (first appearance of Thalassiosira miocenica) is correlative with the base of Burckle's $T$. convexa Zone, which occurs late in magnetic Epoch 6 (approximately 6.2 m.y.; Berggren and Van Couvering, 1974). This horizon should therefore approximate the evolutionary appearance of Stichocorys peregrina at the base of the $S$. peregrina Zone (Theyer and Hammond, 1974). At Site 238 the base of TID 15 lies slightly above the $S$. peregrina/O. penultimus $Z$ one boundary. It also falls within N17 and the Ceratolithus primus Zone. This diatom boundary appears to occur at a lower biostratigraphic position in the northeast Pacific than in the Indian Ocean. At 


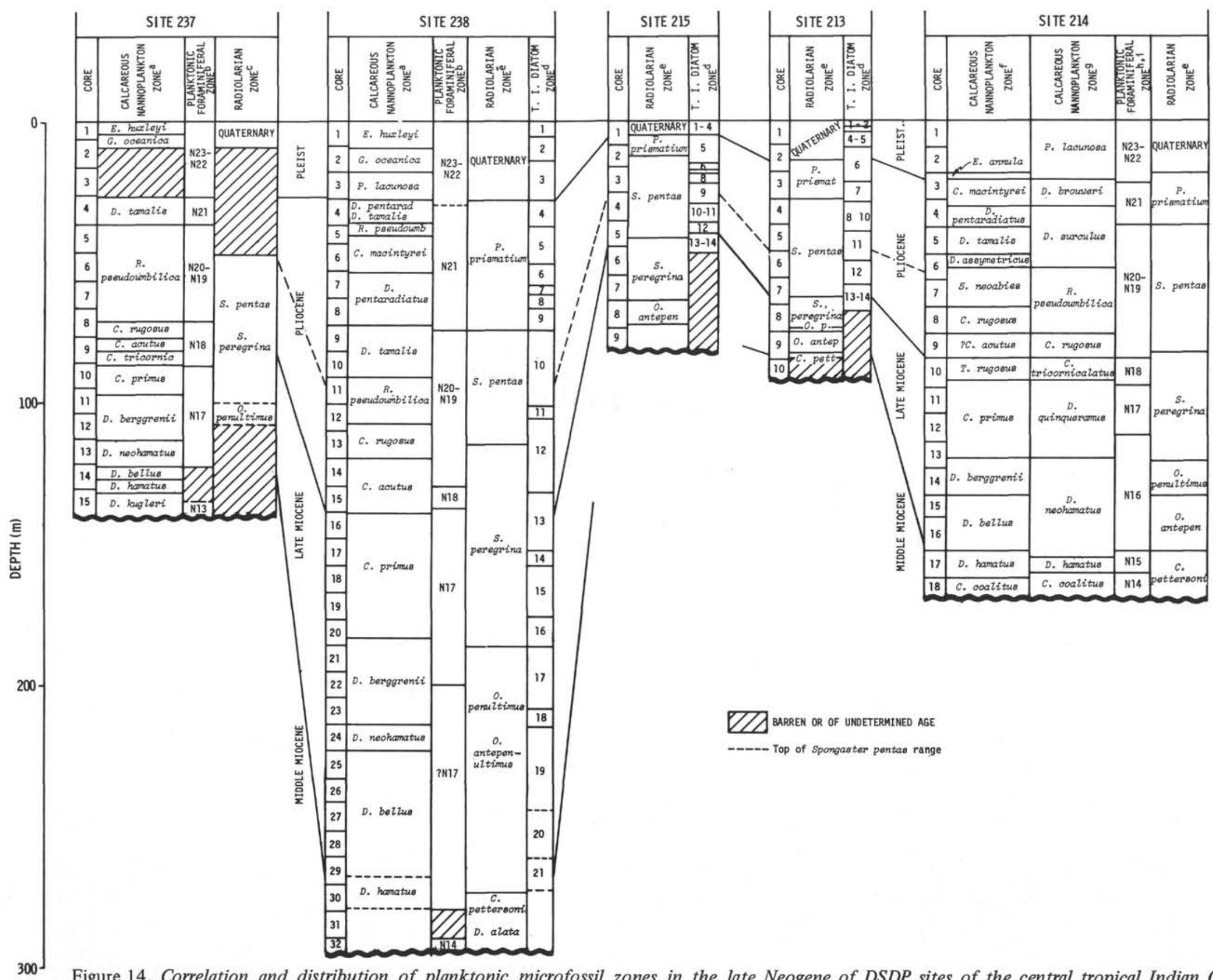

300

Figure 14. Correlation and distribution of planktonic microfossil zones in the late Neogene of DSDP sites of the central tropical Indian Ocean. See Figure 13 for site location. $a=$ Roth (this volume); Bukry (this volume), using Roth's zonation; $b=$ Vincent, Frerichs, and Heiman (this volume); $c=$ Sanfilippo and Riedel (this volume); $d=$ Schrader (this volume); $e=$ Johnson (1974); $f=$ Bukry (1974); $g=$ Gartner (1974); $h=$ Berggren, Lohman, and Poore (1974); $i=$ McGowran (1974). 
Site 173 the base of NPD 12 (equivalent to the base of TID 15) lies near the N17/N16 boundary and within the Discoaster variabilis Zone, a cool-water zone which covers the interval equivalent to the $D$. exilis through $D$. neohamatus zones of tropical regions (D. Bukry, personal communication).

The TID 19/TID 20 boundary, correlative with the base of the Nitzschia porteri Zone of Burckle (1972), is defined by the extinction level of Coscinodiscus yabei and falls in the middle part of magnetic Epoch 8 (approximately 8.38.4 m.y. B.P.). At Site 238 the TID 19/TID 20 boundary lies within the Ommatartus antepenultimus (radiolarian) and Discoaster bellus (nannofossil) zones and co-occurs with a foraminiferal fauna of indeterminate but probably pre-N17 age. This level is earlier than the biostratigraphic position (early $O$. penultimus, $\mathrm{NN} 11$, and early N17) reported to correlate with the extinction level of $C$. yabei in the equatorial Pacific by Berggren and Van Couvering (1974, their fig. 3). A similar discrepancy was noted in the northeast Pacific, where the NPD 16/NPD 17 boundary is equivalent to the TID 19/TID 20 boundary.

The base of TID 21 is placed at the highest appearance of Denticula hustedtii, slightly above the last occurrence of Coscinodiscus temperei. TID 21 is correlative to Burckle's (1972) C. yabei Zone, whose base was not defined. The base of TID 21 at Site 238 approximates the Discoaster bellus/D. hamatus and Ommatartus antepenultimus/Cannartus pettersoni Zone boundaries and in turn the late/ middle Miocene boundary within magnetic Epoch 10 (approximately 11 m.y. B.P.; Berggren and Van Couvering, 1974). This diatom event is equivalent to the NPD 18/NPD 19 boundary, which, however, falls within calcareous plankton zones (Sphenolithus heteromorphus and N12) older than those associated with the base of TID 21 at Site 238.

In conclusion, the biostratigraphic position of a number of the TID zone boundaries varies from site to site (Figure 11). The locations of some of these boundaries, however, are consistent when compared to the evolutionary sequences of other microfossil groups. The TID zonal boundaries which appear most reliable are indicated in Figure 3.

The Pleistocene/Pliocene boundary is not well marked by diatom events in the tropical Indian Ocean. The youngest appearance of the radiolarian Pterocanium prismatium, one of the criteria defining this horizon, occurs at the TID 3/TID 4 boundary at Site 238, at the TID 4/TID 5 boundary at Site 215, and within TID 6 at Site 213. Pseudoeunotia doliolus, a species known to evolve during the Olduvai event in the equatorial Pacific, first appears in the tropical Indian Ocean either above or below the Pliocene/ Pleistocene boundary as defined by other fossil groups.

The Pliocene/Miocene boundary, which approximates the Stichocorys pentas/S. peregrina radiolarian Zone boundary, lies within TID 13 (undifferentiated TID 13/TID 14 at Sites 213 and 215), slightly below the TID 12/TID 13 boundary. The late/middle Miocene boundary correlates with the base of TID 21, but the equivalent NPD level is within the middle Miocene in the northeast Pacific.

\section{CONCLUSIONS ON EPOCH BOUNDARIES}

A number of paleontological events which are closely associated with the Olduvai normal paleomagnetic event
(Gilsa event of Cox, 1969), approximately 1.7-1.8 m.y. B.P., have been used as criteria for defining the Pliocene/ Pleistocene boundary. These include the extinctions of the nannofossil genus Discoaster (in the form of D. brouweri), and the radiolarian Pterocanium prismatium and the evolutionary appearances of the foraminiferal species Globorotalia truncatulinoides and the diatom Pseudoeunotia doliolus (Ericson et al., 1963; Banner and Blow, 1965; Berggren et al., 1967; Glass et al., 1967, Burckle, 1969; Hays and Berggren, 1971). These events, however, are not simultaneous. It has been noted that Discoaster brouweri became extinct, and Pseudoeunotia doliolus appeared during the Olduvai event, while the Pterocanium prismatium extinction and Globorotalia truncatulinoides appearance occurred just after the Olduvai event (Burckle, 1969; Hays et al., 1969). The youngest occurrence of Discoaster brouweri has been used in this report to define the Pliocene/ Pleistocene boundary. In the deep-sea pelagic calcareous sequences of the tropical Indian ocean, such as those at Sites 214 and 236, the youngest occurrence of Discoaster and Pterocanium prismatium and the oldest occurrence of $G$. truncatulinoides are no more than a few meters apart, while in the expanded hemipelagic sections of the Gulf of Aden these events are separated by up to 60 meters. Pseudoeunotia doliolus was found to be of no value in defining the Pliocene/Pleistocene boundary in the tropical Indian Ocean because the level of its first appearance varies with respect to the boundary as defined by other fossil groups.

The biostratigraphic value of the Globorotalia truncatulinoides evolutionary appearance may be questionable, as it has been suggested that the earliest appearance of this species is not simultaneous in various water masses (Kaneps, 1970, 1973; Kennett, 1973; Kennett and Gietzenauer, 1969; Theyer, 1973). Further difficulty in using this datum results from the application of differing interpretations of the "first appearance" of G. truncatulinoides. Some workers have placed this event at the first common occurrence of this species and others at the first appearance of isolated specimens. At the central western Indian Ocean sites of Leg 24, where the sedimentation rate is slow, $G$. truncatulinoides is common at the horizon of its first appearance. At the Gulf of Aden sites, in contrast, where rapid sedimentation has produced an expanded stratigraphic section, this species occurs as rare and isolated specimens for up to 60 meters below the level at which it becomes common.

The Miocene/Pliocene boundary in the Mediterranean has been correlated with the first occurrence of the nannofossil Ceratolithus acutus ${ }^{3}$ (Bukry, 1971a). This event, which coincides with the evolutionary appearance of Globorotalia tumida tumida (base of N18), is within the lowermost reversed interval of the Gilbert paleomagnetic epoch, approximately 4.9 m.y. B.P. (Gartner, 1973; Saito

\footnotetext{
${ }^{3}$ Ceratolithus armatus Müller, 1974, is a senior subjective synonym of $C$. acutus Gartner and Bukry, in press (Bukry, personal communication). The latter taxon was a nomen nudum at the time of publication of Müller's report. This species has been referred by Gartner (1973) to $C$. sp., and by many authors, incorrectly, to $C$. amplificus. The C. acutus Subzone of Bukry (1974) and C. acutus Zone of Roth (this volume) should, therefore, be changed to the $C$. armatus Subzone and Zone.
} 
et al., in press). On the basis of these data, Berggren and Van Couvering (1974) placed the Miocene/Pliocene boundary at 5 m.y. The first appearance of Pterocanium prismatium and thus the Spongaster pentas/Stichocorys peregrina Zone boundary (as defined by Riedel and Sanfilippo, 1970 ) lies at or very near this horizon (Berggren and Van Couvering, 1974; Theyer and Hammond, 1974). Good agreement for the definition of the Miocene/Pliocene boundary was found among the various fossil groups in the tropical western Indian Ocean.

Discrepancies were found between nannofossil and foraminiferal zonations in locating the middle/late Miocene boundary. The foraminiferal zonation indicates a higher stratigraphic position for this horizon at Sites 231 and 236 than indicated by nannofossils, and a lower position at Sites 237 and 238. This inconsistency suggests that the discrepancy is not due to a relationship of the fossil zones to the time scale different from that indicated in Figure 3, but rather to contemporaneous faunal mixing and sediment reworking. An interval with mixed middle and upper Miocene foraminiferal faunas spans the boundary at all sites. The higher of the alternative sedimentation rate curves for the middle Miocene interval (Figures 5, 10, 11, and 12) indicates a decrease in sedimentation rate at about 12 m.y. B.P. Sediments accumulated only one-third as rapidly in the later part of the middle Miocene as in the early part. An increase in bottom water circulation was probably responsible for a period of nondeposition or of reworking in the whole western Indian Ocean at that time. Similar redeposition was noted above an unconformity spanning the middle/late Miocene boundary in the adjacent Arabian Sea (Fleisher, 1974).

The early Miocene, Oligocene, and late Eocene are not well suited for detailed biostratigraphic investigation because the sequence is condensed and the preservation of foraminiferal faunas is poor. Discrepancies were found between nannofossil and foraminiferal determinations of the Oligocene/Miocene boundary, which was arbitrarily based on nannofossil data. Dissolution is significant in the condensed series at Sites 236 and 237. In the more expanded section, with better preservation, at Site 238, base of foraminiferal Zone N4 (Globigerinoides datum) is somewhat lower than the Oligocene/Miocene boundary of the nannofossil zonation (base of the Triquetrorhabdulus carinatus Zone of Roth). This observation is consistent with recent reports that Globigerinoides probably evolved earlier than the stratigraphic horizon indicated by Blow (1969). Blow correlated the base of Zone N4, defined by the evolutionary appearance of $G$. primordius (the Globigerinoides datum), with the base of the Aquitanian, the lowermost stage of the Miocene. The Aquitanian stratotype, however, rests on a transgressive unconformity; in more complete stratigraphic sections in the Aquitanian Basin, the Globigerinoides datum occurs well below the level of the base of the stratotype (Anglada 1971; Scott, 1972). In Puerto Rico, Globigerinoides primordius has been observed to appear before Globorotalia kugleri (Seiglie, 1973), and in Barbados the Globigerinoides datum is equivalent to a level in the Sphenolithus ciperoensis (NP 25) nannofossil Zone (Lohman, personal communication).
An interval of slow or nondeposition spanning the Paleocene/Eocene boundary at Sites 236 and 237 precluded a detailed biostratigraphic investigation of the latter. Correlation of epoch boundaries between Leg 24 sites is shown in Figure 15.

\section{COMPARISON BETWEEN THE MAGNETIC AND BIOSTRATIGRAPHIC AGE OF SEDIMENT-BASEMENT CONTACTS}

The relationship between basement depth and age is illustrated in Figure 16; none of the Leg 24 sites at which basement was reached fits well with the theoretical curve of Sclater et al. (1971). Only Site 236 was drilled on identifiable magnetic anomalies (Figure 17), approximately 60 miles north of Anomaly 28 (67.7-68.5 m.y. B.P.; Heirtzler et al., 1968) as identified by McKenzie and Sclater (1971). Extrapolation of a spreading (half) rate of $6.5 \mathrm{~cm} / \mathrm{yr}$, as proposed by these authors, indicates that the site lies near Anomaly 27 (66.6-67.1 m.y.). In contrast, faunal evidences suggest a considerably younger basement; the sediment directly above the basalt contains fossils attributable to the Discoaster mohleri nannofossil Zone of Roth (1973) and Bukry (1974), and to the early Planorotalites pseudomenardii (P4) foraminiferal Zone (57-58 m.y. B.P.; Berggren, 1972). A similar discrepancy has been noted at all DSDP sites which have been drilled on or close to wellidentified magnetic anomalies, and at which a good contact between basement and Paleocene or early Eocene basal sediments has been observed. These include Sites 213 and 245 in the Indian Ocean, Site 19 in the Atlantic, and Sites 38 and 39 in the Pacific. The biostratigraphic age at all these sites is 5-7 m.y. less than the magnetic age. It has thus been suggested that the Heirtzler et al. (1968) paleomagnetic scale should be adjusted and ages reduced by a factor of about $7 \%$ for the early Cenozoic (Schlich, 1974; Sclater et al., 1974). The magnetic age at Site 236 would thus be $62-63$ m.y. The discrepancy with the biostratigraphic age is still substantial, suggesting a depositional hiatus between basement and the basal sediment (within Core 33) at Site 236.

Magnetic lineations in the area of Site 236 are associated with the Carlsberg Ridge, or a proto-Carlsberg Ridge, the postulated spreading center responsible for the separation of the Seychelles block from India. Results from Site 236 incorporating the adjustment of the magnetic time scale indicate that these two continental blocks sundered (if indeed they were once united) later than currently believed.

Sediment inclusions in the basalt at Site 235 , located east of the Owen/Chain Fracture Zone in the magnetically quiet western Somali Basin, contain a late Maestrichtian flora (65-67 m.y., Micula mura nannofossil Zone of Roth, 1973); this age would correspond to Anomaly 27 (66.7. 67.1 m.y. B.P.; Heirtzler et al., 1968). Site 235 (Figure 17) is located, however, on the northwestward prolongation of magnetic lineations equivalent to Anomaly 25 (62.8-63.3 m.y.). The discrepancy between these two ages would be even greater if an adjusted magnetic scale for the early Cenozoic were used, as proposed by Schlich (1974) and Sclater et al. (1974). This discrepancy implies the presence of a transform fault between Site 235 and the magnetic 
$\vec{\omega}$

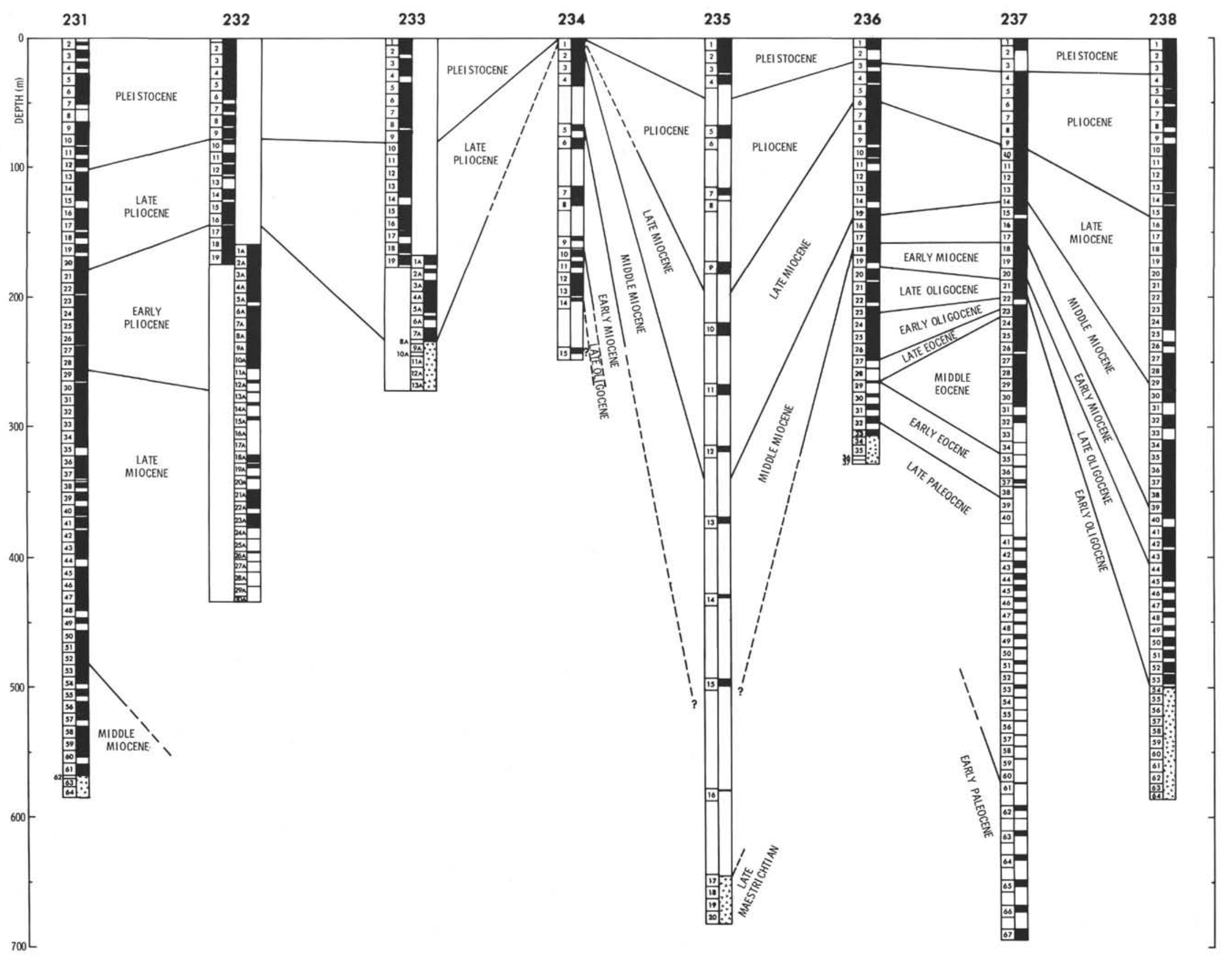

Figure 15. Correlation of epoch boundaries in Leg 24 DSDP sites. 


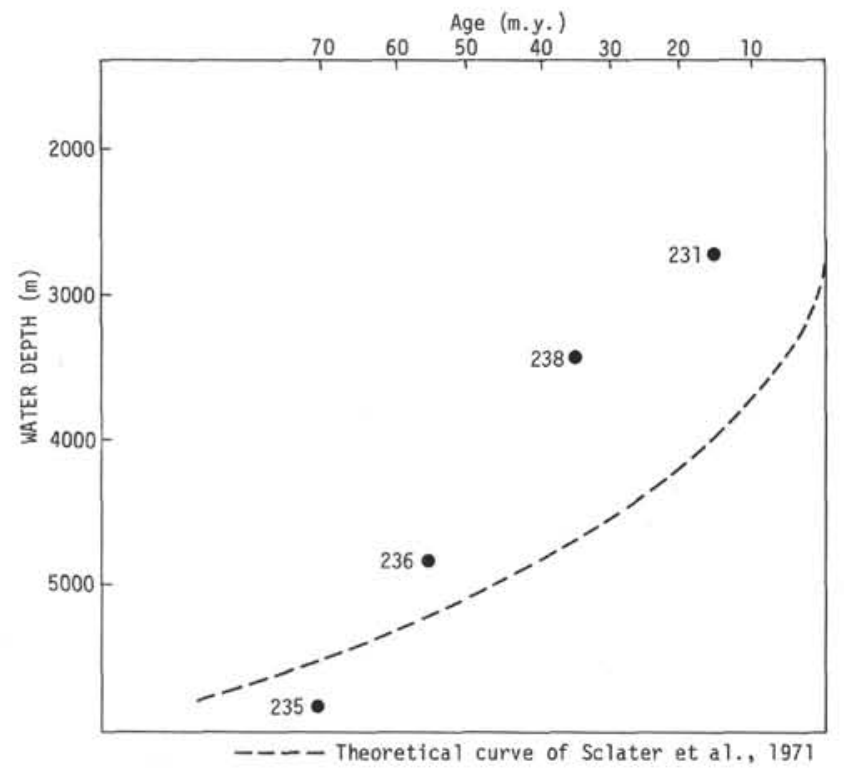

Figure 16. Basement age versus depth for Sites 231, 235, 236, and 238. Age based on biostratigraphic age of basal sediment.

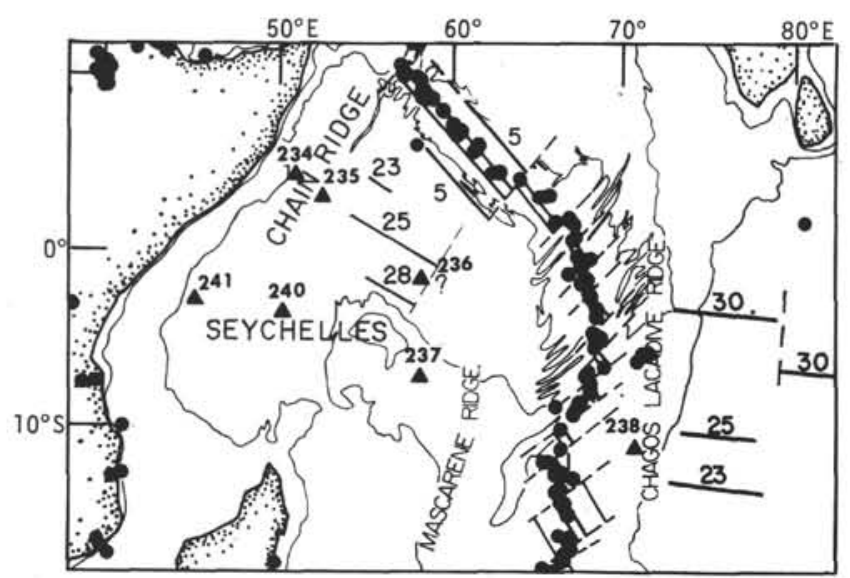

Figure 17. DSDP Leg 24 Sites 234, 235, 236, 237, and 238 and Leg 25 Sites 240 and 241 superimposed on a diagram of magnetic anomalies from McKenzie and Sclater (1971).

lineations identified to the east, and an offset of the magnetic anomalies to the north.

The biostratigraphic age of the oldest sediment at Site 238 , ( 4.5 meters above basement) is late early Oligocene (32-34 m.y.; P. 19 and Sphenolithus distentus Zone). This age corresponds approximately to Anomalies $10-11$ of the Heirtzler et al. (1968) magnetic time scale. Unfortunately, no magnetic interpretation is available for this seismically active area. As it is very likely that the oceanic crust at Site 238 formed at the Central Indian Ridge, the age of 32-34 m.y. is thus a minimum age for the spreading activity of this structure. The date of sundering of the Chagos and Saya de Malha regions (Fisher et al., 1971) is therefore at least as old as early Oligocene.
The age of approximately 13 m.y. for the sedimentbasement contact at Site 231 (Sphenolithus heteromorphus Zone for sediment inclusions in the basalt, and Zone N12 just above basement) is in good agreement with the magnetic age of the site, which is located beyond Anomaly 5 in the Gulf of Aden (Figure 18).

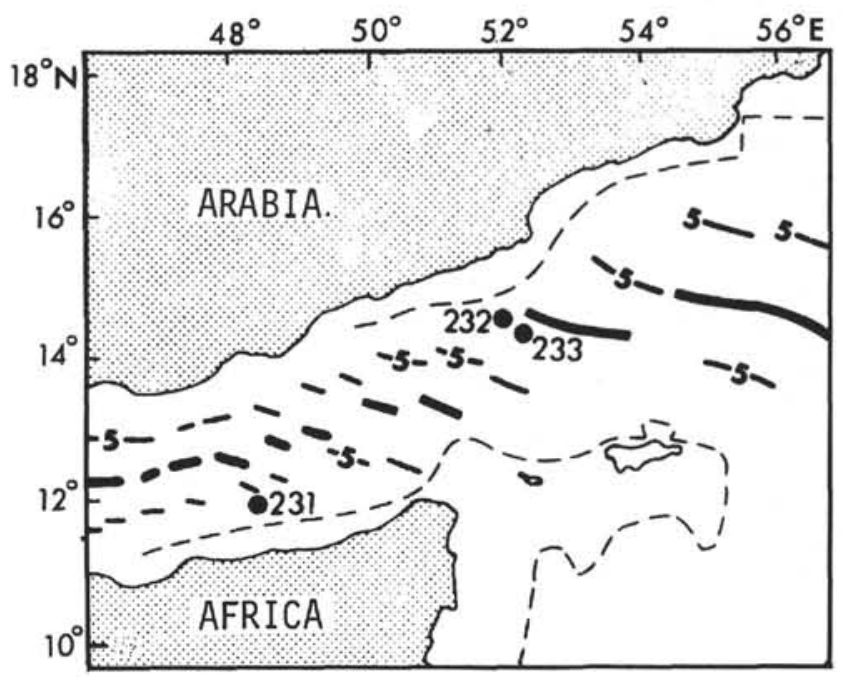

Figure 18. Magnetic anomalies of the Gulf of Aden and location of DSDP Sites 231, 232, and 233 (from Whitmarsh, 1974).

\section{PALEOENVIRONMENTAL DEPOSITION AND PALEOCEANOGRAPHY}

Surface and Bottom Water Circulation in the Tropical Western Indian Ocean

Bottom water circulation and the productivity of surface water masses are the main factors controlling the nature and rate of accumulation of sediments and the type and distribution of microfossils. All sites drilled during Leg 24 lie under the Indian Ocean Equatorial Water mass (Sverdrup et al., 1942). The Gulf of Aden sites are situated close to the continental margin, in an area of prevalent hemipelagic sedimentation. The Indian Ocean sites, however, located within an open-ocean pelagic environment, lie beneath the high productivity belt associated with the south equatorial divergence, a region characterized by a high content of siliceous microfossils in the underlying sediments (Kozlova, 1971; Lisitzin, 1971; Riedel, 1971).

The Indian Ocean differs from other major oceanic basins in the presence of a land mass to the north. The resultant seasonal changes in wind conditions produce corresponding and marked changes in the equatorial current system. The South Equatorial Current (between about $8^{\circ} \mathrm{S}$ and $20^{\circ} \mathrm{S}$ ) is a permanent feature of the circulation pattern throughout the year. From November to March, when the northeast monsoon prevails, the westward North Equatorial Current (between $2^{\circ} \mathrm{S}$ and $6^{\circ}$ to $10^{\circ} \mathrm{N}$ ) is well developed, and an Equatorial Countercurrent is present (between $8^{\circ} \mathrm{S}$ and $2^{\circ} \mathrm{S}$ ). From May to September, during the period of southwest monsoons, the North Equatorial Current is replaced by an eastward Southwest Monsoon Current, and the Equatorial 
Counter Current disappears or becomes indistinguishable from the Monsoon Current (Figure 19).

Surface circulation in the Arabian Sea and Gulf of Aden also varies greatly from winter to summer in response to seasonal variations in wind direction. During the northeast monsoon period the circulation pattern forms a counterclockwise gyre, while during the southwest monsoon the currents are set in a clockwise direction. During the latter period pronounced upwelling takes place all along the Arabian coast, and surface water temperatures drop considerably. The monsoonal winds are probably a prime factor influencing eolian sedimentation, which plays an important role at all sites drilled in the Gulf of Aden.

The deep-water circulation pattern of the Indian Ocean is little known. A southward deep current of highly saline, poorly oxygenated water has long been recognized (Schott, 1926; Matthews, 1927; Möller, 1929, 1933; Thomsen, 1933, 1935). This water, formed by the sinking of surface waters from the coastal regions of the Arabian Sea and neighboring gulfs and from the Red Sea, is known as North Indian Deep Water (termed Red Sea Water by Sverdrup et al., 1942). Its southern extension is not well defined although it has been detected as far south as $40^{\circ} \mathrm{S}$ in various parts of the Indian Ocean (Deacon, 1937; Clowes, 1950; Le Pichon, 1960 ) and $25^{\circ} \mathrm{S}$ in the Mozambique Channel (Vincent, 1972). Tchernia et al. (1951) noted that the southward movement of North Indian Deep Water is more pronounced in the west of the Indian Ocean than in the east.

Deep water from the Circumpolar Current moves northward in the Indian Ocean into the western Crozet Basin and flows east of Madagascar through the Madagascar and Mascarene basins as a typical deep western boundary current (Le Pichon, 1960; Warren, 1971, 1974; Wyrtki, 1971). Cold bottom water appears to cross the West Indian Ridge near $27^{\circ} \mathrm{S}, 60-65^{\circ} \mathrm{E}$, as shown by water property distribution (Warren, 1974) as well as by the distribution in the sediments of calcium carbonate and of Antarctic diatom assemblages (Burckle et al., 1974). It is uncertain what fraction of Antarctic Bottom Water continues northward into the Somali Basin. A large part of the Antarctic Bottom Water rises to upper levels at about $10^{\circ} \mathrm{S}$ and mixes at intermediate depths with North Indian Deep Water and Antarctic Intermediate Water. The mixed water sinks to greater depth and returns southward (Tchernia et al., 1958). Part of the Antarctic Bottom Water, however, flows north into the Arabian Sea after having been considerably transformed. Here it rises to shoaler depth and returns southward in the intermediate current of North Indian Deep Water (Gallagher, 1966). Burckle et al. (1974) detected Antarctic diatoms as far north as $5^{\circ} \mathrm{N}$ in the western Indian Ocean.

The composition of the microfossil assemblages strongly reflects this pattern of surface water circulation.

All of the various fossil assemblages recovered from Leg 24 sediments are characteristic of tropical waters. Modern planktonic foraminiferal faunas at the central western Indian Ocean sites $(236,237$, and 238$)$ contain warm-water associations similar in species composition to the biocoenoses of the tropical Indian Ocean (Bé and Tolderlund, 1971; Boltovskoy, 1969; Belyaeva, 1964). The Gulf of Aden assemblages, however, are distinct from the open-ocean assemblages in that they include a higher percentage of cool
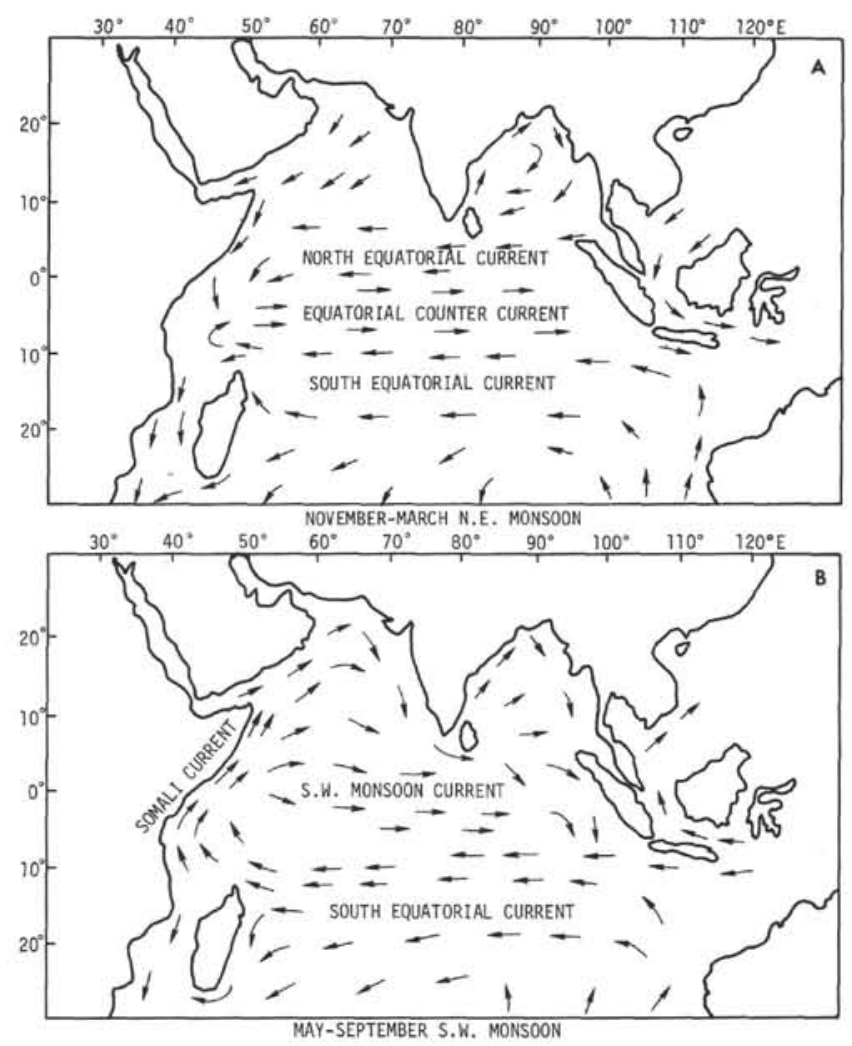

Figure 19. Surface circulation in the Indian Ocean. (a) November-March (northeast monsoon). (b) MaySeptember (southwest monsoon).

water species. This "cooler" aspect may result in part from selective dissolution of warm-water species, as dissolution is significant in the Gulf of Aden, but the high relative abundance of Turborotalia pachyderma is unusual for these low latitudes. This species is as common here than in assemblages under the Indian Ocean Central Water (Swerdrup et al., 1942) at $32^{\circ} \mathrm{S}$ on the Madagascar Plateau (Vincent, 1972), and is present in Arabian Sea and southern Red Sea assemblages as well (Fleisher, 1974). This distribution may reflect control not only by temperature but also by special conditions of high salinity and low oxygen content in these waters.

Faunal assemblages present a "tropical" aspect throughout the recovered Cenozoic sequences and do not, therefore, reflect significant latitudinal changes at the sites.

Fluctuations in Biogenic Components Abundance and in Productivity

Changes in sedimentation rates and fluctuations in the abundance of major biogenic constituents in the sediments provide clues to the depositional and paleoenvironmental history at these sites. Variations of the main biogenic components in the total sediments, as estimated from smear slides are shown in Figures 20 to 22, and Figures 23 to 25 illustrate variations in the relative frequency of the main pelagic components and of foraminiferal faunal composition in the sediment coarse fraction $(>63 \mu)$.

Increases in the abundance of silica relative to carbonate in sediments can generally be related to such factors as 


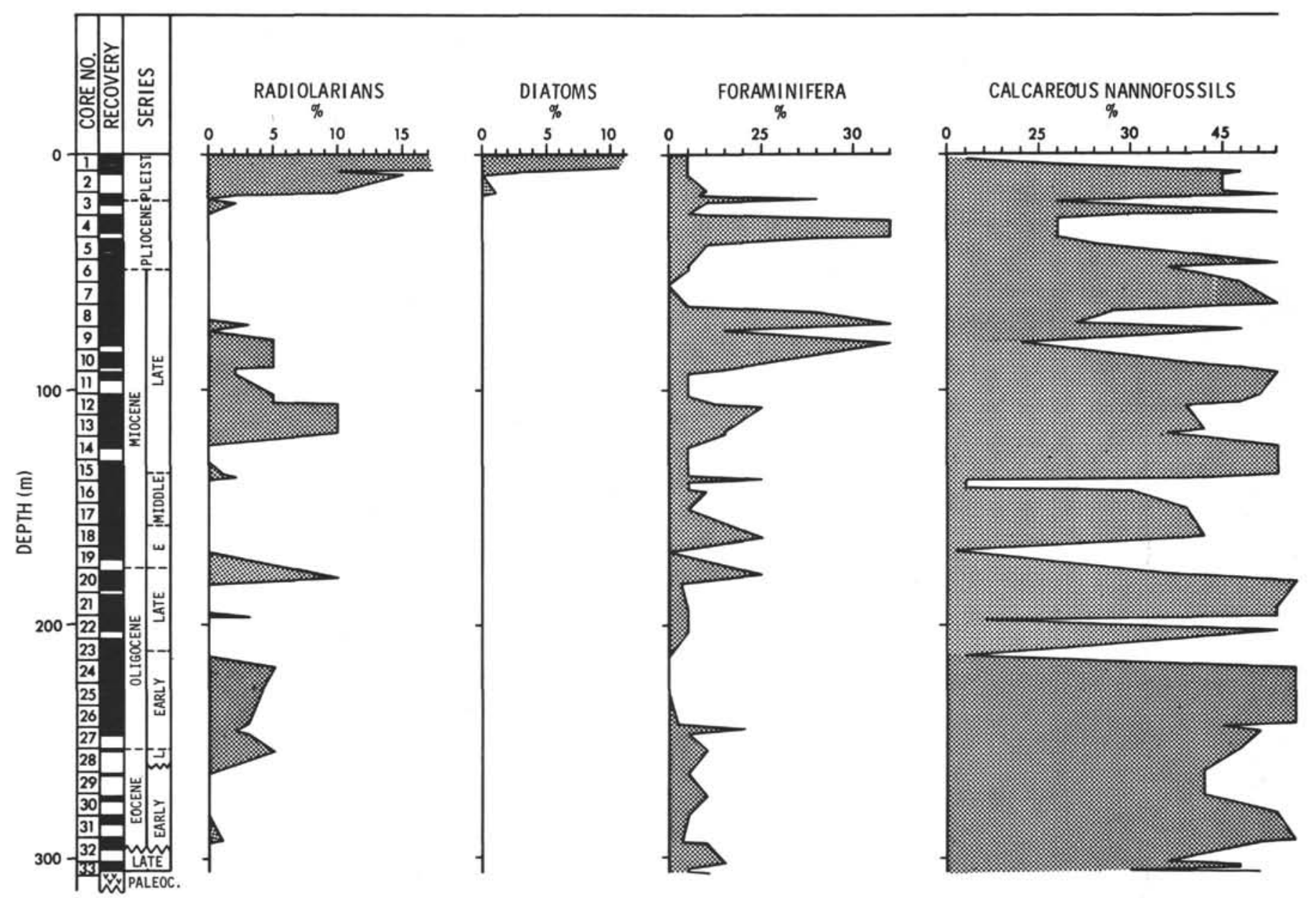

Figure 20. Variations in the relative abundance of main biogenic components in sediments at Site 236 (visually estimated from smear-slide analyses).

(1) increased dissolution of calcareous material; (2) onset of high productivity in the surface waters at a given site; or (3) transport of the site under an already existing high productivity zone (such as an equatorial belt) due to plate motion. It is not always possible to distinguish between these factors, and their effects may be combined.

The abundance of siliceous material in the central western Indian Ocean in Eocene time was probably not related to plate motion but rather to high productivity of surface waters. Chert and biogenic silica occur in contemporaneous early Cenozoic sequences of various sites in the Arabian Sea and eastern and western central Indian Ocean without apparent relation to their paleolatitudes or paleodepths. According to available tectonic reconstructions of the Indian Ocean (McKenzie and Sclater, 1971; Sclater and Fisher, 1974; Pimm, 1974; Whitmarsh, 1974), there has been little change in paleolatitudes for the western sites during much of the Cenozoic, while sites on the Ninetyeast Ridge occupied latitudes in the early Cenozoic much farther south than their modern position. The abundance of siliceous remains and chert decreases to the east in the Paleocene and Eocene sequences of the central Indian Ocean. Siliceous sediments are much more abundant in the Arabian Sea (Whitmarsh et al., 1974) and the Mascarene Plateau area than on the Ninetyeast Ridge, and are absent in the Wharton Basin (von der Borch et al., 1974). This systematic variation may possibly be related to the distinct surface circulation patterns prevailing east and west of India at that time. India during the early Paleogene occupied the middle of the Indian Ocean (McKenzie and Sclater, 1971; McElhinny, 1970), and while sites east of India were under the influence of a great gyral circulation presumably driven by the Pacific south equatorial current through a north Australian seaway (Frakes and Kemp, 1972), sites west of India were under the influence of a more regional circulation pattern favorable to siliceous production.

The abrupt decrease in skeletal siliceous components below 300 meters at Site 237 and below 260 meters at Site 236 (Figures 20,21) correlates well with the youngest occurrence of chert in these sequences. Most of the siliceous material originally present in the sediment thus has probably been recrystallized into chert, a process described by Lancelot (1973). The presence of siliceous remains in the upper Paleocene interval between Cores 43 and 54 at Site 237 may reflect a slight decrease in postdepositional silica remobilization. Below Core 54 the disappearance of most biogenic components appear to be directly related to the strong recrystallization of both calcareous and siliceous phases. Micarb and chert become the dominant components of these sediments. 


\section{E. VINCENT}

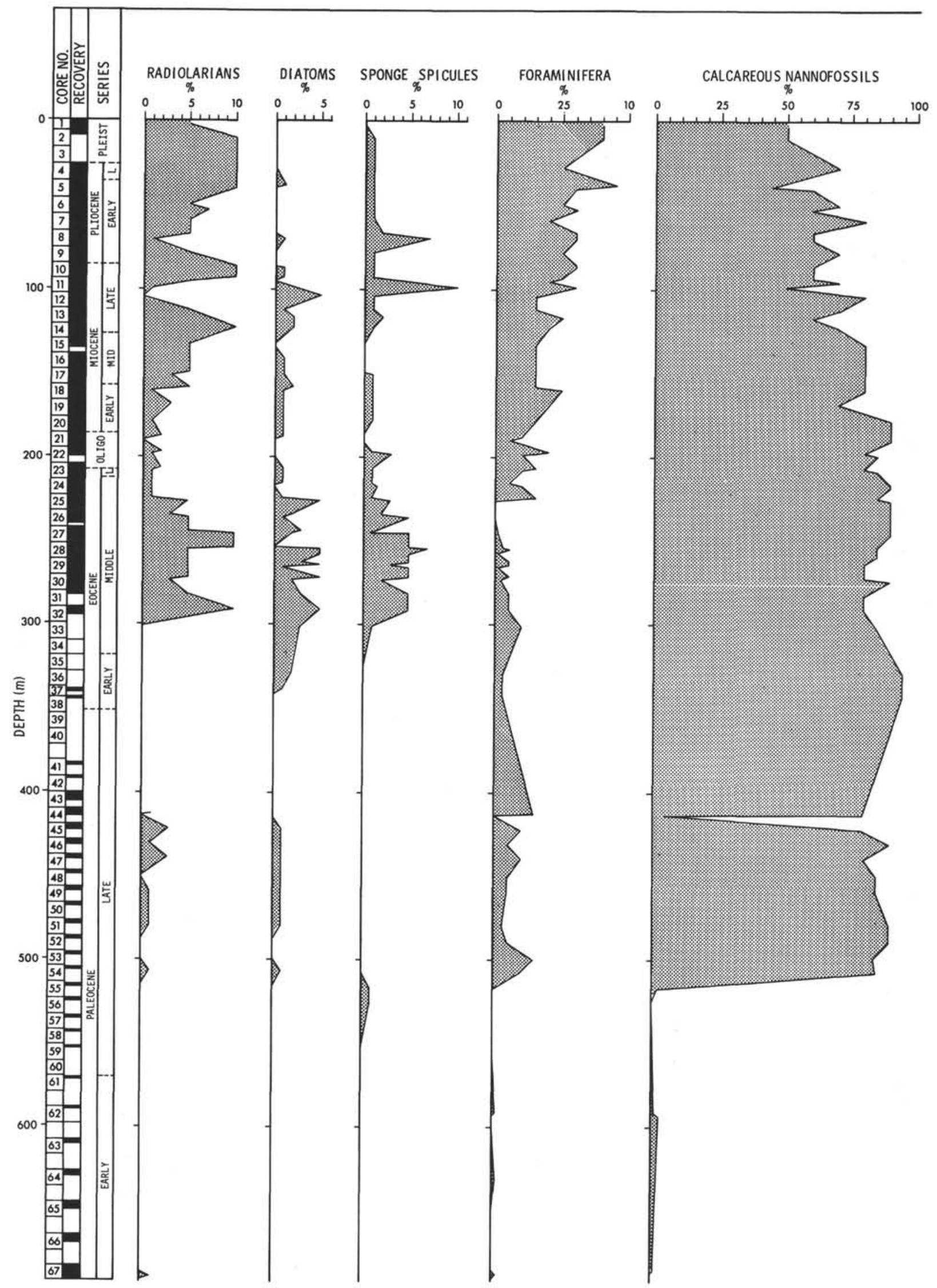

Figure 21. Variations in the relative abundance of main biogenic components in sediments at Site 237 (visually estimated from smear-slide analyses). 


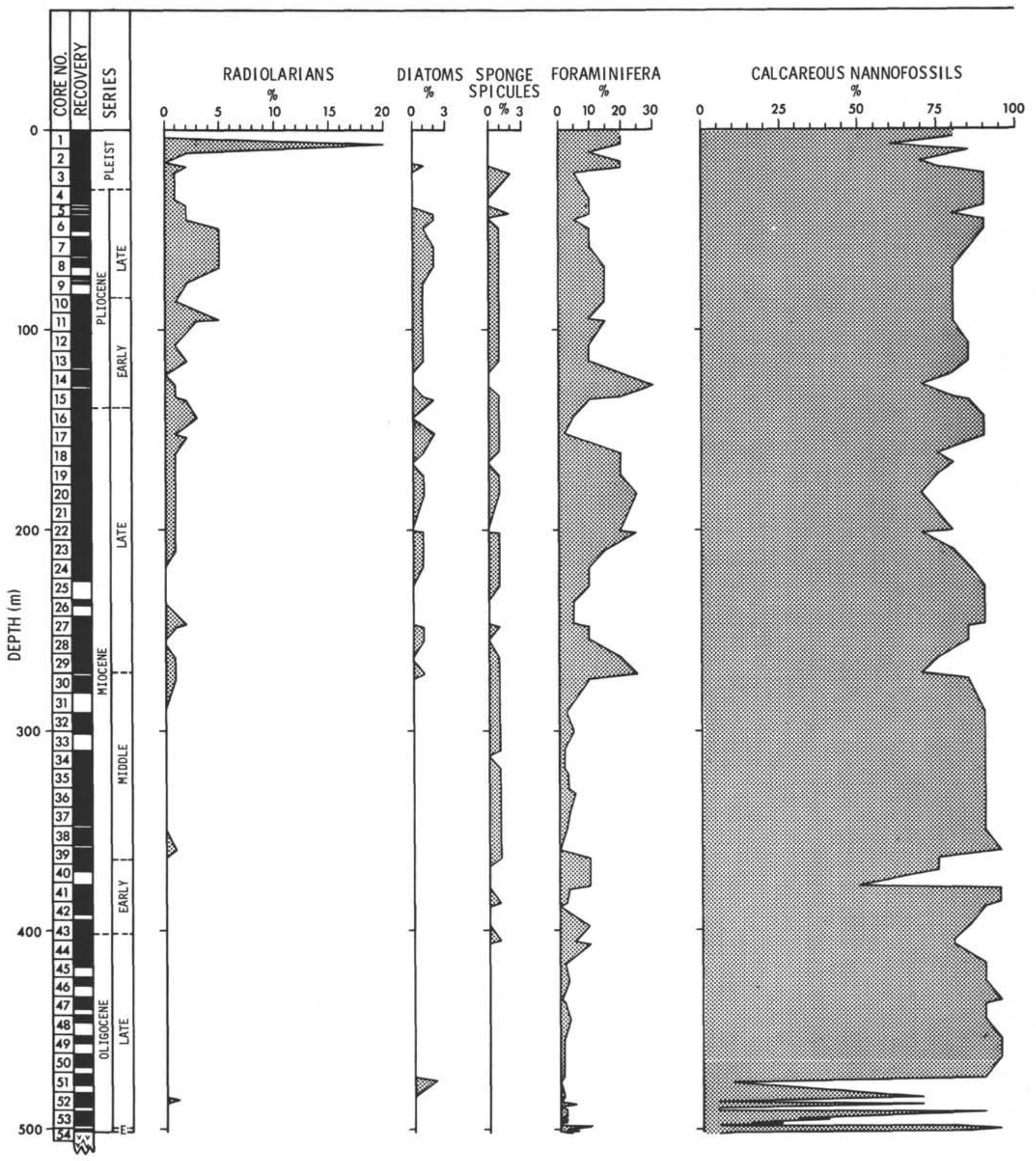

Figure 22. Variations in the relative abundance of main biogenic components in sediments at Site 238 (visually estimated from smear-slide analyses). 


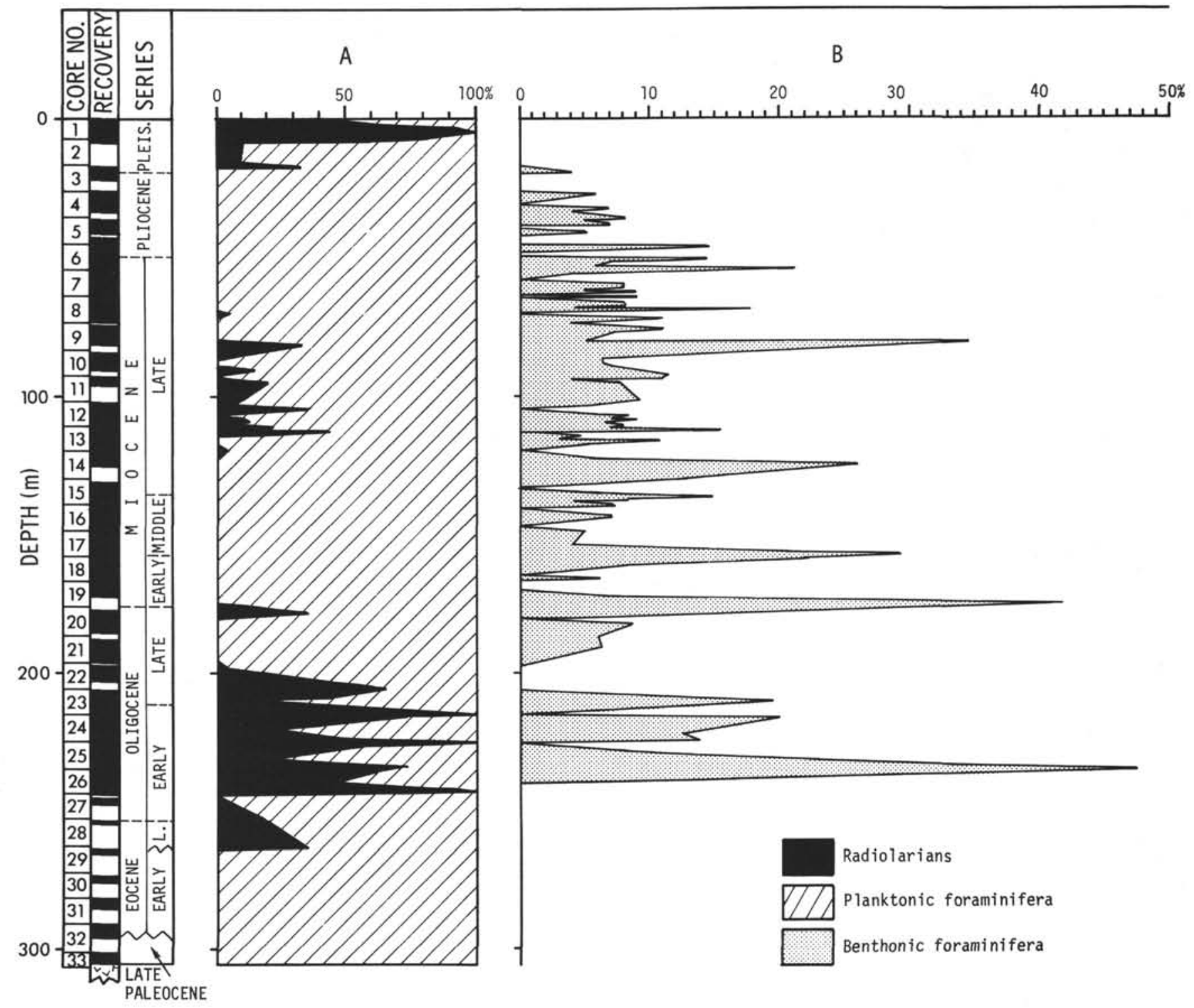

Figure 23. Faunal variations in the sediment coarse fraction $(>63 \mu)$ at Site 236 (data from Thiede, this volume). (a) Relative frequency of radiolarians and planktonic foraminifera. (b) Percentages of benthonic foraminifera in the total foraminiferal populations.

The increase in radiolarian abundance and associated decrease in foraminifera in the lower Oligocene at Site 236, a pattern not observed at Site 237 , is probably related to calcium carbonate solution. Paleodepth reconstruction from subsidence of oceanic crust (Sclater et al., 1971; Berger, 1973 ) at those Leg 24 Sites which reached basement (Figure 26) shows that Site 236 was approximately 3500 meters deep in the early Oligocene, a time when the CCD may have been shallower.

Biogenic silica and foraminifera content, as well as the overall rate of sediment accumulation, have increased throughout the late Neogene. This trend observed at all tropical sites of the Indian Ocean very probably reflects a progressive increase in the productivity of the overlying water mass. The modern equatorial circulation pattern in the Indian Ocean, with the development of a high productivity belt, thus appears to have formed at the end of the middle Miocene, when India had moved north of the Equator.

\section{Depth of Deposition, Displaced Faunas and Nondepositional Intervals}

Benthonic foraminiferal assemblages in recovered sediments in Leg 24 are typical of present water depths at the sites and do not show significant changes throughout the sections. Neritic benthonic foraminifera, however, occur commonly in the Pliocene and Pleistocene sections of Site 231 and in the Paleocene of Site 237. In both cases they are associated with skeletal debris of calcareous algae, bryozoans, molluscs, and are slumped from nearby shelf areas (Vincent, Gibson and Brun, this volume). Abraded tests of shallow water benthonic foraminifera were also occasionally found throughout the Neogene section of Site 236. 


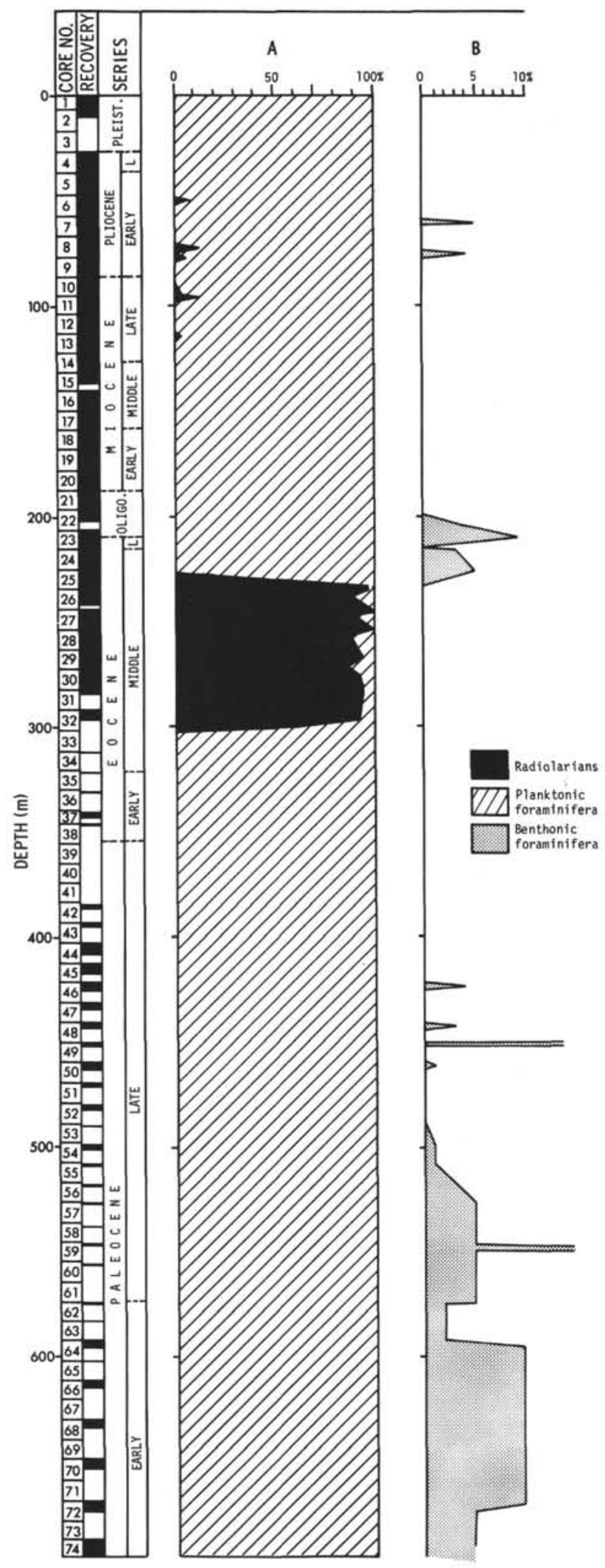

Figure 24. Faunal variations in the sediments of Site 237. Above 500 meters: variations in the sediment coarse fraction (data from Thiede, this volume). Below 500 meters: variations visually estimated in thin sections (data from Vincent, Gibson, and Brun, this volume). (a) Relative frequency of radiolarians and planktonic foraminifera. (b) Percentages of benthonic foraminifera in the total foraminiferal populations.

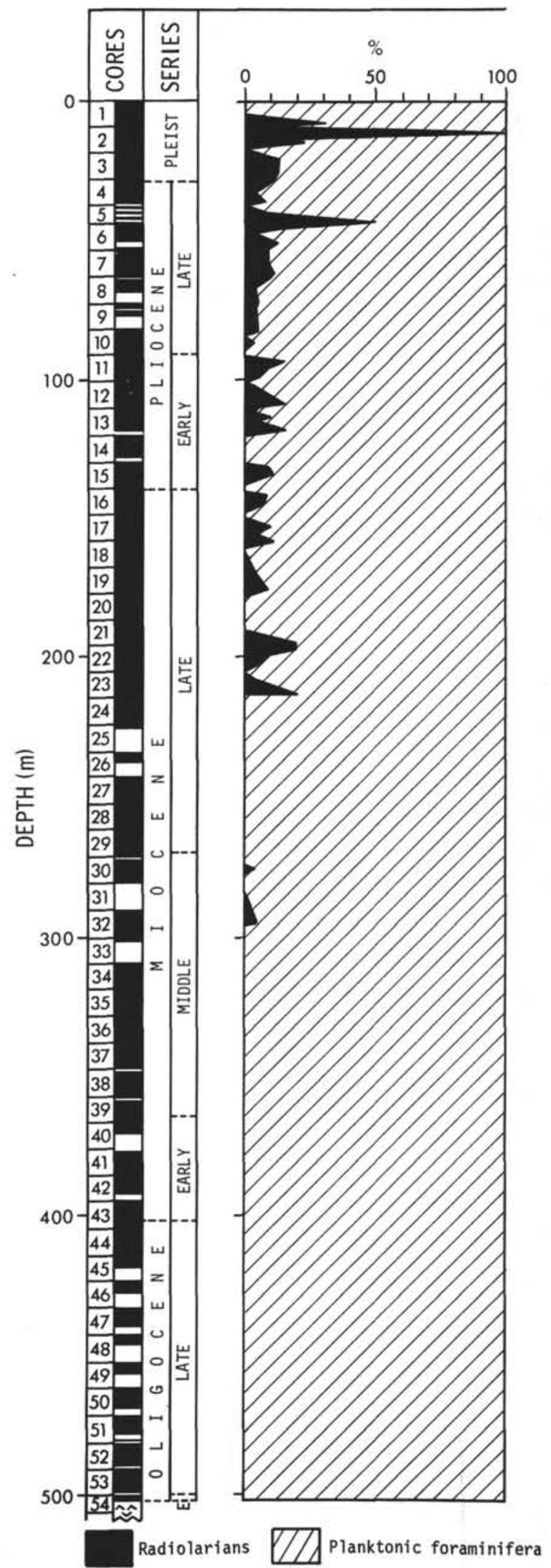

Figure 25. Variations in the relative frequency of radiolarians and planktonic foraminifera in the sediment coarse fraction $(>63 \mu$ ) at Site 238 (data from Thiede, this volume). 


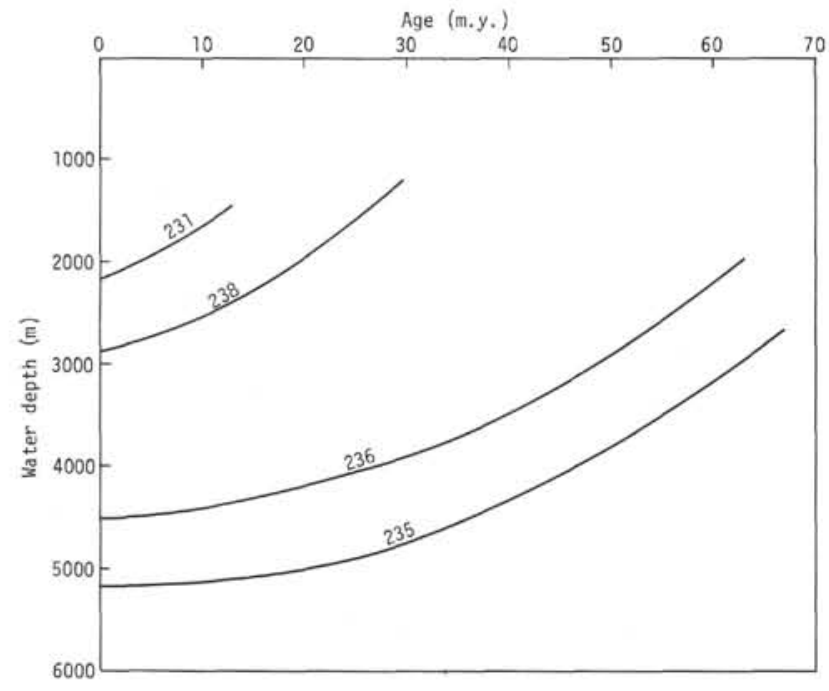

Figure 26. Paleodepths at Sites 231, 235, 236, and 238 obtained using Lohmann's (personal communication) method similar to that of Berger $(1972,1973)$ derived from Sclater et al., 1971.

Displacement of bathyal sediments into deeper bathyal water is difficult to detect, as allochthonous and autochthonous benthonic assemblages are similar in composition. Evidence indicating such displacement, however, may include pronounced sorting, biostratigraphic mixing, or mixing of faunas with different styles of preservation. Such displacements are apparent at several sites.

Paleodepth reconstruction at Site 235 (Figure 26) shows that this Site has probably been located below the CCD since at least early Eocene time. Results from Sites 213 and 215 , on either side of the Nintyeast Ridge, suggest that the CCD was situated at depths of 3600 and 3300 meters at 51 and 53 m.y. B.P., respectively (Pimm, 1974). Wellpreserved and well-sorted calcareous faunas, however, are, present in many horizons, and probably represent turbidite fractions.

Displacement is common throughout the section at Site 236 , where coarse-grained oozes are intercalated with finegrained oozes. The coarse-grained oozes, which contain better preserved foraminiferal faunas with a smaller proportion of benthonic species (Figure 23), appear to have originated at depths shallower than those prevailing at the site. The presence of occasional abraded neritic foraminiferal tests and granite grains in these layers may indicate that they originated to the south, from the Seychells block. The sedimentary record of Site 236 shows that during early Miocene time this site was probably close to the level of the CCD, which was then below 4000 meters (Figure 26), somewhat deeper than in other ocean basins at that time (Berger, 1972-1973).

Significant reworking of older sediments is notable in the Pliocene sections of Sites 236 and 238, on the present sea floor at Site 238, and in early late Miocene at all sites.

Besides turbidite displacement (as at the Somali Basin sites) or slumping from nearby shelves or shoals (as in the Gulf of Aden during Pliocene and Pleistocene time, and on the Mascarene Plateau during the Paleocene), it is probable that the significant reworking within the calcareous oozes recovered during Leg 24 is related to major bottom current activity. The major effect on bottom sediments of a deep western boundary current of corrosive Antarctic Bottom Water has been recognized in other oceans as well (Fox et al., 1968; Johnson, 1972). It seems probable, therefore, that the reworking, condensing of stratigraphic sections, and intervals of nondeposition found at Leg 24 sites are related to the northward flow of Antarctic Bottom Water.

The broadly uniform trends in the deposition of calcareous oozes in the central western Indian Ocean can be discerned from a comparison of sedimentation rates (Figures 5 to 12). From late Eocene to early Miocene times, the sections are strongly condensed, and sediment accumulated much more slowly than during preceding and succeeding intervals. Similar patterns of nondeposition or very slow sedimentation have been noted in Oligocene intervals in the eastern Indian Ocean and Arabian Sea (Whitmarsh et al., 1974; von der Borch et al., 1974). This broad-scale pattern reflects a time of strong bottom current activity throughout a large part of the Indian Ocean, which is probably related to the introduction of northward-moving Antarctic Bottom Water. The formation of this water mass reflects a major global cooling induced by Antarctic glaciation of Oligocene age, which also resulted in an unconformity between Australia and New Zealand (Kennett et al., 1972). Active sedimentation resumed in the middle Miocene and remained high throughout the late Neogene. During the late Miocene, the modern south equatorial surface circulation pattern became established, with resultant high surface-water productivity. Bottom current activities are reflected by episodes of reworking, particularly in the early late Miocene following a short interval of slowed deposition between approximately 12.5 and 10 m.y.B.P.

Although the sedimentation rate curve for Site 238 is similar to those derived for Sites 236 and 237, sediments accumulated here 3 times more rapidly than at the two latter sites. This increased depositional activity possibly reflects penecontemporaneous reworking at this site, a result of its location close to the ridge crest and to an active transform fault.

A short interval of nondeposition or very slow accumulation spanning the Paleocene/Eocene boundary has been noted at various deep (236) and shallow sites $(237,219$, $214,216,217)$ on the Mascarene Plateau, Chagos-Laccadive Ridge, and Ninetyeast Ridge (Whitmarsh et al., 1974; von der Borch et al., 1974). These occurrences suggest that this unconformity is related to a large-scale oceanographic activity.

\section{CONCLUSIONS}

In light of the evidence discussed above, it is possible to recognize a number of major events in the Cenozoic sedimentary and oceanographic history of the western tropical Indian Ocean. All planktonic assemblages recovered throughout the Cenozoic are tropical in aspect, suggesting that Leg 24 sites did not undergo significant latitudinal change during the Cenozoic.

The Paleocene record prior to 58 m.y.B.P. can be interpreted only from Site 237 on the Mascarene Plateau, where 300 meters of recrystallized nannofossil chalk was recovered. This section represents a pelagic sequence deposited at upper bathyal depths, with an added influx 
of neritic material slumped from nearby shoals (Vincent, Gibson, and Brun, this volume). After deepening of Site 237 in the late Paleocene, normal pelagic sedimentation proceeded at a much slower rate, similar to that calculated for the equivalent interval at Site 236. A further decrease in the rate of sedimentation occurred during a 5-m.y. interval spanning the Paleocene/Eocene boundary, a period of nondeposition at Site 236. Similar hiatuses reported from the Chagos-Laccadive Ridge and Ninetyeast Ridge have been interpreted as reflection of local tectonism affecting only shallow depths (Pimm and Sclater, in press), but the deep-water unconformity at Site 236 (approximately $2800 \mathrm{~m}$ deep at the time) suggests the action of factors related to broad-scale oceanographic activity.

The Paleocene and Eocene are characterized by abundant siliceous material primarily in the form of radiolarians, largely remobilized to form chert in the lower Eocene and Paleocene horizons. The paleoposition of India in the middle of the Indian Ocean resulted in different surface circulation patterns west and east of the subcontinent, which may account for the difference in silica content between the eastern and western Indian Ocean sites.

In the late Eocene-early Oligocene, when Antarctic Bottom Water moved northward into the Indian Ocean, the accumulation rate and preservation of calcareous ooze decreased. During the Oligocene and early Miocene, preservation of planktonic foraminifera remained poor and hiatuses or condensed series occur during this interval. In middle to late Miocene time, when India moved north of the equator, the onset of the modern south equatorial circulation pattern resulted in higher productivity, reflected in middle Miocene to Quaternary sequences by higher sedimentation rates and higher content of siliceous microfossils.

An episode of reworking in the early late Miocene, following a 2 m.y. interval of reduced sedimentation spanning the middle/late Miocene boundary, reflects an increased large-scale bottom current activity in the central western Indian Ocean, Gulf of Aden, and Arabian Sea.

This interpretation is of necessity based upon a preliminary analysis of the evidence made available from Leg 24 drilling.

The Gulf of Aden and central western Indian Ocean sites are notable in that coring is continuous and recovery good. It seems likely that further detailed study of the material recovered will provide a more complete understanding of the history of the western Indian Ocean.

\section{ACKNOWLEDGMENTS}

The cooperation of R. L. Fisher and E. T. Bunce, CoChief Scientists for Leg 24, in obtaining continuous biostratigraphic sequences is greatly appreciated. To other paleontologists who studied Leg 24 material, P. H. Roth, A. Sanfilippo, W. R. Riedel, J. Thiede, H. J. Schrader, M. E. Heiman, W. E. Frerichs, and D. Bukry, whose data I have extensively used in this report, I give my thanks. Valuable discussions with W. A. Berggren, Y. Lancelot, G. P. Lohmann, and R. Schlich have been a great asset in the preparation of this report. A special thanks to R. L. Fleisher who critically and constructively reviewed the manuscript and to J. Roslund whose assistance in handling the data was invaluable.
This study was supported under Oceanographic Section, National Science Foundation NSF Grant GA-34145 and represents Contribution No. 350, Department of Geological Sciences, University of Southern California.

\section{REFERENCES}

Anglada, R., 1971. Sur la position du datum à Globigerinoides (Foraminiferida) la zone N4 (Blow 1967) et la limite oligo-miocène en Méditerranée: C. R. Acad. Sci., Paris, v. 272, p. 1067-1070.

Banner, F. T. and Blow, W. H., 1965. Progress in the planktonic foraminiferal biostratigraphy of the Neogene: Nature, v. 208, p. 1164-1166.

Bé, A. W. H. and Tolderlund, D. S., 1971. Distribution and ecology of living planktonic foraminifera in surface waters of the Atlantic and Indian Oceans. In Funnell, B. M. and Riedel, W. R. (Eds.), The micropalaeontology of the oceans: Cambridge, Cambridge University Press, p. 105-149.

Beckman, J. P., 1971. The foraminifera of sites 68 to 75 . In Tracey, J. I., Jr., et al., 1971, Initial Reports of the Deep Sea Drilling Project, Volume 8: Washington (U. S. Government Printing Office), p. 713-725.

Beliaeva, N. V., 1964. Raspredelenie planktonnykh foraminifer $\mathrm{v}$ vodakh i na dnie Indiiskogo Okeana. (Distribution of planktonic foraminifera in the water and on the floor of the Indian Ocean): Trudy Inst. Okeanol., Akad. NAUKK SSSR, v. 68 , p. 12-83.

Berger, W. H., 1972. Deep sea carbonates: dissolution facies and age depth constancy: Nature, v. 236, p. 392395 .

1973. Cenozoic sedimentation in the Eastern Tropical Pacific: Geol. Soc. Am. Bull., v. 84, p. 19411954.

Berggren, W. A., 1972. A Cenozoic time-scale-some implications for regional geology and paleobiogeography: Lethaia, v. 15, p. 195-215. 1973. The Pliocene time scale: calibration of planktonic foraminiferal and calcareous nannoplankton zones: Nature, v. 243, p. 391-397.

Berggren, W. A. and Van Couvering, J. A., in press. The late Neogene: Biostratigraphy, biochronology and paleoclimotology of the last 15 million years in marine and continental sediments: Paleogeography, Paleoecology, Paleoclimatology, v. 16.

Berggren, W. A., Lohmann, G. P. and Poore, R. Z., 1974. Shore laboratory report on Cenozoic planktonic foraminifera. In von der Borch, C. C., et al., 1974, Initial Reports of the Deep Sea Drilling Project, Volume 12: Washington (U. S. Government Printing Office), p. 635655.

Berggren, W. A., Phillips, J. D., Bertels, A., and Wall, D., 1967. Late Pliocene-Pleistocene stratigraphy in deep-sea cores from the south central North Atlantic: Nature, v. 216 , p. $253-254$.

Blow, W. H., 1969. Late Middle Eocene to Recent planktonic foraminiferal biostratigraphy: Int. Conf. Plankt. Microfossils, 1st, Proc., Brönnimann, P. and Renz, H. H. (Eds.), Leiden (Brill), v. 1, p. 199-422.

Boltovskoy, E., 1969. Living planktonic foraminifera at the $90^{\circ} \mathrm{E}$. meridian from the equator to the Antarctic: Micropaleontology, v. 15, p. 237-255.

Bukry, D., 1971a. Cenozoic calcareous nannofossils from the Pacific Ocean: San Diego Soc. Nat. History Trans., v. 16 , p. 303-327.

Bukry, D., 1971b. Coccolith stratigraphy, Leg 8, Deep Sea Drilling Project. In Tracey, J. I., Jr., et al., 1971, Initial 
Reports of the Deep Sea Drilling Project, Volume 8: Washington (U. S. Government Printing Office), p. 791807.

Bukry, D., 1972. Coccolith stratigraphy, Leg 9, Deep Sea Drilling Project. In Hays, J. D., et al., 1972, Initial Reports of the Deep Sea Drilling Project, Volume 9: Washington (U. S. Government Printing Office), p. 817832 .

1973. Coccolith and silicoflagellate stratigraphy, Deep Sea Drilling Project, Leg 18, Eastern North Pacific. In Kulm, L. D., von Huene, R., et al., Initial Reports of the Deep Sea Drilling Project, Volume 18: Washington (U.S. Government Printing Office), p. 817-832.

1973b. Coccolith stratigraphy, Leg 10, Deep Sea Drilling Project. In Worzel, J. L., Bryant, W., et al., 1973, Initial Reports of the Deep Sea Drilling Project, Volume 10: Washington (U. S. Government Printing Office), p. $385-406$.

1974a. Coccolith stratigraphy, Arabian and Red seas, Deep Sea Drilling Project Leg 23. In Whitmarsh, R. B., Weser, O. E., Ross, D. A., et al., 1974, Initial Reports of the Deep Sea Drilling Project, Volume 23: Washington (U. S. Government Printing Office), p. 1091 1093.

, 1974. Low-latitude coccolith biostratigraphy zonation. In Edgar, N. T., Saunders, J. B., et al., Initial Reports of the Deep Sea Drilling Project, Volume 15: Washington (U.S. Government Printing Office), p. 685704.

Bunce, E. T., Langseth, M. G., Chase, R. L., and Ewing, M., 1967. Structure of the western Somali Basin: J. Geophys. Res., v. 72, p. 2547-2555.

Burckle, L. H., 1969. Late Cenozoic planktonic diatom zones in Equatorial Pacific sediments (abs.). Geol. Soc. Am. Abstracts for 1969 Part 7, p. 24.

1972. Late Cenozoic planktonic diatom zones from the Eastern Equatorial Pacific: Beih. Nova Hedwigia-Heft 39, p. 217-246.

Burckle, L. H., Venkatarathnam, K., and Booth, J. D., 1974. Sediment transport by Antarctic Bottom Water in the western Indian Ocean. Am. Geophys. Union, Trans., v. 55 , p. 312 .

Bystricka H., 1971. Sur la position stratigraphique de la zone à Discoaster sublodoensis: Acta Geol. Geogr. Universitatis Comenianae, Nr. 23, p. 115-120.

Clowes, A. J., 1950. An introduction to the hydrology of South African Waters: Invest. Rep. Fish. Mar. Biol. Surv., S. Africa, no. 12, p. 1-42.

Cox, A., 1969. Geomagnetic reversals: Science, v. 163, p. 237-245.

Deacon, G. E. R., 1937. The hydrology of the Southern Ocean: Discovery Rep., Cambridge, v. 15, p. 1-123.

Ericson, D. B., Ewing, M., and Wollin, G., 1963. PliocenePleistocene boundary in deep-sea sediments: Science, v. 139 , p. $727-737$

Fisher, R. L., Engel, G. G., and Hilde, T. W. C., 1968. Basalts dredged from the Amirante Ridge, Western Indian Ocean: Deep-Sea Res., v. 15, p. 521-534.

Fisher, R. L., Johnson, G. L., and Heezen, B. C., 1967. Mascarene Plateau, Western Indian Ocean: Geol. Soc. Am. Bull., v. 78, p. 1247-1266.

Fisher, R. L., Sclater, J. G., and Mckenzie, D. P., 1971. The evolution of the Central Indian Ridge, Western Indian Ocean: Geol. Soc. Am., Bull. v. 82, p. 553-562.

Fleisher, R. L., 1974. Cenozoic planktonic foraminifera and biostratigraphy, Arabian Sea, Deep Sea Drilling Proj- ect, Leg 23A. In Whitmarsh, R. B., Weser O. E., Ross, D. A., et al., Initial Reports of the Deep Sea Drilling Project, Volume 23: Washington (U.S. Government Printing Office), p. 1001-1074.

Foreman, H. P., 1973. Radiolaria of Leg 10 with systematics and ranges for the families Amphypyndacidae, Artostrobiidae, and Theoperidae. In Worzel, J. L., Bryant, W., et al., Initial Reports of the Deep Sea Drilling Project, Volume 10: Washington (U.S. Government Printing Office), p. 407-474.

Frakes, L. A. and Kemp, E. M., 1972. Influence of continental positions on early Tertiary climates: Nature, v. 240, p. $97-100$.

Gallagher, J. F., 1966. The variability of water masses in the Indian Ocean: N.O.D.C., Pub. G11, 74 p.

Gartner, S., 1973. Absolute chronology of the late Neogene calcareous nannofossil succession in the Equatorial $\mathrm{Pa}$ cific: Geol. Soc. Am. Bull., v. 84, p. 2021-2034.

Gartner, S., Jr., 1974. Nannofossil biostratigraphy, Leg 22, Deep Sea Drilling Project. In von der Borch, C. C., Sclater, J. G., et al., Initial Reports of the Deep Sea Drilling Project, Volume 22: Washington (U.S. Government Printing Office), p. 577-600.

Gartner, S., Jr. and Bukry, D., in press. Taxonomy and stratigraphy of Ceratolithus: Tulane Bull.

Glass, B., Ericson, D. B., Heezen, B. C., Opdyke, N. D., and Glass, J. A., 1967. Geomagnetic reversals and Pleistocene chronology: Nature, v. 216, p. 437-442.

Hays, J. D. and Berggren, W. H., 1971. Quaternary Boundaries. In Funnel, B. M. and Riedel, W. R. (Eds), Micropalaeontology of oceans: Cambridge, Cambridge Univ. Press.

Hays, J. D., Saito, T., Opdyke, N. D., and Burckle, L. H., 1969. Pliocene-Pleistocene sediments of the equatorial Pacific: their paleomagnetic, biostratigraphic, and climatic record: Am. Bull. Geol. Soc., v. 80, p. 1481.

Heirtzler, J. R., Dickson, G. O., Herron, E. M., Pitman, W. C., and Le Pichon, X., 1968. Marine magnetic anomalies, geomagnetic field reversals and motions of the Ocean floor and continents: J. Geophys. Res., v. 73, p. $2119-$ 2136.

Ingle, J. C., Jr., 1973. Neogene foraminifera from the Northeastern Pacific Ocean, Leg 18, Deep Sea Drilling Project, In Kulm, L. D., von Huene, R., et al., Initial Reports of the Deep Sea Drilling Project, Volume 18: Washington (U.S. Government Printing Office), p. $517-$ 568.

Jenkins, D. C. and Orr, W. N., 1972. Planktonic foraminiferal biostratigraphy of the eastern Equatorial Pacific Deep Sea Drilling Project, Leg 9. In Hollister, C. D., Ewing, J. I., et al., 1972, Initial Reports of the Deep Sea Drilling Project, Volume 9: Washington (U. S. Government Printing Office), p. 1060-1193.

Johnson, D. A., 1972. Eastward-flowing bottom currents along the Clipperto fracture zone: Deep-Sea Res.,v.19, p. 253-257.

1974. Radioloria from the Eastern Indian Ocean, DSDP Leg 22. In von der Borch, C. C., Sclater, J. G., et al., Initial Reports of the Deep Sea Drilling Project, Volume 22: Washington (U.S. Government Printing Office), p. 521-576.

Kaneps, A. G., 1970. Late Neogene biostratigraphy (planktonic foraminifera), biogeography, and depositional history. PhD thesis, Columbia University, New York, 185 p. 1973. Cenozoic planktonic foraminifera from the eastern equatorial Pacific Ocean. In van Andel, T. H., Heath, G. R., et al., Initial Reports of the Deep Sea Drill- 
ing Project, Volume 16: Washington (U.S. Government Printing Office), p. 713-746.

Kennett, J. P., 1973. Middle and Late Cenozoic planktonic foraminiferal biostratigraphy of the southwest PacificDSDP Leg 21. In Burns, R. E., Andrews, J. E., et al., Initial Reports of the Deep Sea Drilling Project, Volume 21: Washington (U.S. Government Printing Office), p. $575-640$.

Kennett, J. P., Burns, R. E., Andrews, J. E., Churkin, M., Jr., Davies, T. A., Dumitrica, P., Edwards, A. R., Galehouse, J. S., Packham, G. H., and van der Lingen, G. J., 1972. Australian-Antarctic continental drift, Palaeocirculation changes and Oligocene deep-sea erosion: Nature, v. 239, p. 51-55.

Kennett, J. P. and Geitzenauer, K. R., 1969. The PliocenePleistocene boundary in a South Pacific deep-sea core: Nature, v. 224 , p. 899.

Kozlova, O. G., 1971. The main features of diatom and silico-flagellate distribution in the Indian Ocean. In Funnell, B. M. and Riedel, W. R., (Eds.), The Micropalaeontology of Oceans: Cambridge (Cambridge University Press), p. 271-275.

Lancelot, Y., 1973. Chert and silica diagenesis in sediments from the Central Pacific. In Winterer, E. L., Ewing, J. I., et al., Initial Reports of the Deep Sea Drilling Project, Volume 17: Washington (U.S. Government Printing Office), p. 377-406.

Laughton, A. S., Whitmarsh, R. B., and Jones, M. T., 1970. The evolution of the Gulf of Aden: Phil. Trans. Roy. Soc. London, Div. A, v. 267, p. 227-266.

Le Pichon, X., 1960. The deep water circulation in the Southwest Indian Ocean: J. Geophys. Res., v. 65, p. 4061-4074.

Lisitzin, A. P., 1971. Distribution of siliceous microfossils in suspension and bottom sediments: In Funnell, B. M. and Riedel, W. R. (Eds.), The Micropalaeontology of Oceans: Cambridge (Cambridge University Press), p. 173195.

Martini, E., 1971. Standard Tertiary and Quaternary calcareous nannoplankton zonation: Proc. 2nd Plankt. Conf., Rome, 1970, p. 739-785.

Matthews, D. H., Williams, C. A., and Laughton, A. S., 1967. Mid-ocean ridge in the mouth of the Gulf of Aden: Nature, v. 215, p. 1052-1053.

McElhinny, M. W., 1970. Formation of the Indian Ocean: Nature, v. 228, p. 977-979.

McGowran, B., 1974. Foraminifera. In von der Borch, C. C., Sclater, J. G., et al., 1974, Initial Reports of the Deep Sea Drilling Project, Volume 22: Washington (U. S. Government Printing Office), p. 609-627.

McKenzie, D. and Sclater, J. G., 1971. The evolution of the Indian Ocean since the Late Cretaceous: Geophys. J. Roy. Astro. Soc., v. 25, p. 437-528.

McNeely, B. W., 1973. Biostratigraphy of the Mesozoic and Paleogene sediments of the Campeche Embankment area. In Worzel, J. L., Bryant, W., et al., 1973, Initial Reports of the Deep Sea Drilling Project, Volume 10: Washington (U. S. Government Printing Office), p. 679686.

Möller, L., 1929. Die Zirkulation des Indischen Ozeans: Veröff. Inst. Meeresk., Berlin, N. F., A, v. 21, p. 1-48. 1933. Zur Frage der Tiefenzirkulation im Indischen Ozean: Ann. Hydrog. Mar. Meteorol., v. 8/9, p. 233-236.

Müller, C., 1974. Calcareous nannoplankton Leg 25 (Western Indian Ocean). In Simpson E. S. W., Schlich, R., et al., Initial Reports of the Deep Sea Drilling Project, Volume 22: Washington (U.S. Government Printing Office), p. $579-634$.

Pimm, A. C., 1974. Sedimentology and history of the Northeastern Indian Ocean from Late Cretaceous to Recent. In von der Borch, E. C., Sclater, J. G., et al., Initial Reports of the Deep Sea Drilling Project, Volume 22: Washington (U.S. Government Printing Office), p. $717-$ 804.

Pimm, A. C. and Sclater, J. G., in press. Early Tertiary discontinuities in the sediment record of deep sea drilling sites in the Northeastern Indian Ocean: Nature.

Ramsay, A. T. A. and Funnell, B. M., 1969. Upper Tertiary microfossils from the Alula-Fartak Trench, Gulf of Aden: Deep-Sea Res., v. 16, p. 25-43.

Riedel, W. R., 1971. The occurrence of pre-Quaternary radiolaria in deep-sea sediments: In Funnell, B. M. and Riedel, W. R. (Eds.): The palaeontology of Oceans. Cambridge (Cambridge University Press)

Riedel, W. R. and Sanfilippo, A., 1970. Radiolaria, Leg 4, Deep Sea Drilling Project. In Bader, R. G., Gerard, R. D., et al., Initial Reports of the Deep Sea Drilling Project, Volume 4: Washington (U.S. Government Printing Office), p. 503-575.

Riedel, W. R. and Sanfilippo, A., 1971. Cenozoic Radiolaria from the western tropical Pacific, Leg 7. In Winterer, E. L., Riedel, W. R., et al., Initial Reports of the Deep Sea Drilling Project, Volume 7: Washington (U. S. Government Printing Office), p. 1529-1672.

Roth, P. H., 1973. Calcareous nannofossils, Leg 17, Deep Sea Drilling Project. In Winterer, E. L., Ewing, J. I., et al., Initial Reports of the Deep Sea Drilling Project, Volume 17: Washington (U.S. Government Printing Office), p. 675-796.

Saito, T., Burckle, L. and Hays, J. D. In press. Micropaleontologic and paleomagnetic data on the Miocene/ Pliocene boundary. In Saito, T. and Burckle, L. (Eds), Late Neogene epoch boundaries: Micropaleontology Press, Am. Mus. Nat. History.

Sanfilippo, A. and Riedel, W. R., 1973. Cenozoic Radiolaria (exclusive of theoperids, artostrobiids and amphypnydacids) from the Gulf of Mexico, Deep Sea Drilling Project Leg 10. In Worzel, J. L., Bryant, W., et al., Initial Reports of the Deep Sea Drilling Project, Volume 10: Washington (U.S. Government Printing Office), p. 475611.

Schlich, R., 1974. Sea-floor spreading history and deep-sea drilling results in the Madagascar and Mascarene basins, Western Indian Ocean. In Simpson, E. S. W., Schlich, R., et al., Initial Reports of the Deep Sea Drilling Project, Volume 25: Washington (U.S. Government Printing Office), p. 663-678.

Schott, G., 1926. Die Tiefwasserbewegungen des Indischen Ozeans: Ann. Hydrog. Mar. Meteorol., v. 12, p. 417-31.

Schrader, H. J., 1973. Cenozoic diatoms from the Northeast Pacific, Leg 18. In Kulm, L. D., von Huene, R., et al., Initial Reports of the Deep Sea Drilling Project, Volume 18: Washington (U.S. Government Printing Office), p. 673-798.

Sclater, J. G., Anderson, R. N., and Bell, M. L., 1971. Elevation of ridges and the evolution of central eastern $\mathrm{Pa}$ cific: J. Geophys. Res., v. 76, p. 7888-7915.

Sclater, J. G. and Fisher, R. L., 1974. The evolution of the east central Indian Ocean with emphasis on tectonic setting of Ninetyeast Ridge: Geol. Soc. Am. Bull., v. 85, p. 683-702. 
Sclater, J. G., Jarrard, R. D., McGowan, B., Gartner, S., Jr., 1974. Comparison of the magnetic and Biostratigraphic time scales since the Late Cretaceous. In von der Borch, C. C., Sclater, J. G., et al., Initial Reports of the Deep Sea Drilling Project, Volume 22: Washington (U.S. Government Printing Office), p. 381-386.

Scott, G. H., 1972. Phyletic trends for trans-Atlantic lower Neogene Globigerinoides: Rev. Esp. Micropal., v. 3, p. 283-292.

Seiglie, G. A., 1973. Revision of Mid-Tertiary stratigraphy of southwestern Puerto Rico: Am. Assoc. Petrol. Geol. Bull., v. 57, p. 405-406.

Sverdrup, H. U., Johnson, M. W., and Fleming, R. H., 1942. The oceans: New York, (Prentice-Hall).

Tchernia, P., Lacombe, H., and Le Floch, J., 1951. Contribution à l'étude de l'Océan Indien et du secteur adjacent de l'Ocean Antarctique: Cah. Oceanogr., v. 3, p. 414479.

Tchernia, P., Lacombe, H., and Guibout, P., 1958. Sur quelques nouvelles observations hydrologiques relatives à la region équatoriale de l'Océan Indien: Cah. Oceanogr., v. 10 , p. $115-143$.

Theyer, F., 1973. Globorotalia truncatulinoides Datum Plan: evidence for a Gauss (Pliocene) age in subantarctic cores: Nature Phys. Sci., v. 241, p. 142-145.

Theyer, F. and Hammond, S. R., in press. Magnetic polarity sequence and radiolarian zones, Brunhes Epoch to Polarity Epoch 20: Earth Planet. Sci. Newsletters.

Thomsen, H., 1933. The circulation in the depths of the Indian Ocean: Cons. Perm. Intern. Explor. Mer. J. Cons., v. 8 , p. $73-79$.
1935. Entstehung und Verbreitung einiger charakteristischer Wassermassen in dem Indischen und Südlichen Pazifischen Ozean: Ann. Hydrog. Mar. Meteorol., p. 293-305.

Van Couvering, J. A. and Berggren, W. A., in press. The biostratigraphical basis of the Neogene time-scale. In Hazel, J. E. and Kauffman, E. (Eds.), New Concepts in Biostratigraphy: Pal. Soc. Am. Spec. Publ.

Vincent, E., 1972. Oceanography and late Quaternary planktonic foraminifera, Southwestern Indian Ocean: Ph.D. Dissertation, University of Southern California. von der Borch, C. C., Sclater, J. G., et al., 1974. Initial Reports of the Deep Sea Drilling Project, Volume 22: Washington (U.S. Government Printing Office).

Warren, B. A., 1971. Evidence for a deep western boundary current in the South Indian Ocean: Nature, v. 229, p. 1819.

1974. Deep flow in the Madagascar and Mascarene basins: Deep Sea Res., v. 21, p. 1-21.

Whitmarsh, R. B., 1974. Some aspects of plate tectonics in the Arabian Sea. In Whitmarsh, R. B., Weser, O. E.. Ross, D. A., et al., Initial Reports of the Deep Sea Drilling Project, Volume 23: Washington (U.S. Government Printing Office), p. 527-536.

Whitmarsh, R. B., Weser, O. E., et al., 1974. Initial Reports of the Deep Sea Drilling Project, Volume 23: Washington (U.S. Government Printing Office).

Wyrtki, K., 1971. Oceanographic Atlas of the International Indian Ocean Expedition: Washington (U.S. Government Printing Office). 